JULIANA VIEIRA CIRILLO

Avaliação citológica e histopatológica de linfonodos regionais em cães portadores de mastocitomas de graus 1, 2 ou 3 e sua importância na determinação da sobrevida

São Paulo

2014 


\section{Avaliação citológica e histopatológica de linfonodos regionais em cães portadores de mastocitomas de graus 1, 2 ou 3 e sua importância na determinação da sobrevida}

Dissertação apresentada ao Programa de Pós-Graduação em Patologia Experimental e Comparada da Faculdade de Medicina Veterinária e Zootecnia da Universidade de São Paulo para a obtenção do título de Mestre em Ciências

Departamento:

Patologia

Área de Concentração:

Patologia Experimental e Comparada

Orientador:

Profa. Dra ${ }^{a}$. Maria Lúcia Zaidan Dagli

São Paulo 
Autorizo a reprodução parcial ou total desta obra, para fins acadêmicos, desde que citada a fonte.

DADOS INTERNACIONAIS DE CATALOGAÇÃO-NA-PUBLICAÇÃO

(Biblioteca Virginie Buff D’Ápice da Faculdade de Medicina Veterinária e Zootecnia da Universidade de São Paulo)

\begin{tabular}{|c|c|}
\hline \multirow[t]{6}{*}{$\begin{array}{l}\text { T.3067 } \\
\text { FMVZ }\end{array}$} & $\begin{array}{l}\text { Cirillo, Juliana Vieira } \\
\text { Avaliação citológica e histopatológica de linfonodos regionais em cães portadores de mastocitomas } \\
\text { de graus } 1,2 \text { ou } 3 \text { e sua importância na determinação da sobrevida / Juliana Vieira Cirillo. -- } 2014 . \\
165 \text { f. : il. }\end{array}$ \\
\hline & $\begin{array}{l}\text { Dissertação (Mestrado) - Universidade de São Paulo. Faculdade de Medicina Veterinária e } \\
\text { Zootecnia. Departamento de Patologia, São Paulo, } 2015 \text {. }\end{array}$ \\
\hline & Programa de Pós-Graduação: Patologia Experimental e Comparada. \\
\hline & Área de concentração: Patologia Experimental e Comparada. \\
\hline & Orientador: Profa. Dra. Maria Lúcia Zaidan Dagli. \\
\hline & 1. Mastocitoma. 2. Cutâneo. 3. Canino. 4. Linfonodo. 5. Metástase. I. Título. \\
\hline
\end{tabular}


UNIVERSIDADE DE SÃO PAULO

FACULDADE DE MEDIĆINA VETERINÁRIA E ZOOTECNIA

\section{Comissão de Ética no Uso de Animais}

\section{CERTIFICADO}

Certificamos que o Projeto intitulado "Avaliaçăo citologica e histopatológica de linfonodos regionais em cães portadores de mastocitomas caninos de graus 1,2 ou 3 e sua importancia na determinaçăo da sobrevida", protocolado sob o $\mathrm{n}^{\circ} 2709 / 2012$, utilizando 50 (cinquenta) cães, sob a responsabilidade do(a) Profa. Dra. Maria Lucia Zaidan Dagli, foi aprovado em reunião de 26/6/2013 e está de acordo com os princlpios éticos de experimentação animal da Comissão de Êtica no Uso de Animais da Faculdade de Medicina Veterinária e Zootecnia da Universidade de São Paulo.

We certify that the Research "Cytological and histopathological evaluation of regional lymph nodes in dogs with canine mast cell tumors of grades 1, 2 or three and its importance in determining survival", protocol number 2709/2012, utilizing 50 (ffifty) dogs, under the responsibility Profa. Dra. Maria Lucia Zaidan Dagli, was approved in the meeting of day 6/26/2013 and agree with Ethical Principles in Animal Research adopted by Ethic Committee in the Use of Animals of the School of Veterinary Medicine and Animal Science of University of Såo Paulo.

São Paulo, 27 de junho de 2013،

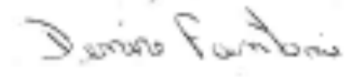

Denise Tabacchi Fantoni Presidente 


\section{FOLHA DE AVALIAÇÃO}

Autor: CIRILLO, Juliana Vieira

Título: Avaliação citológica e histopatológica de linfonodos regionais em cães portadores de mastocitomas de graus 1,2 ou 3 e sua importância na determinação da sobrevida

Dissertação apresentada ao Programa de PósGraduação em Patologia Experimental e Comparada da Faculdade de Medicina Veterinária e Zootecnia da Universidade de São Paulo para obtenção do título de Mestre em Ciências

Data:

\section{Banca Examinadora}

Prof. Dr.

Instituição: Julgamento:

Prof. Dr.

Instituição: Julgamento:

Prof. Dr.

Instituição: Julgamento: 


\section{Dedicatória}

Dedico este trabafho aos meus pais, que nunca mediram esforços para me proporcionar o meffior ensino. Ofrigada mäe, pai e Garol, por todo o amor e carintio e por sempre acreditarem em mim! 'Dedido também ao meu querido avô... foi graças ao nosso sitio que descobri o dom de me doar aos animais! ... e a minfia

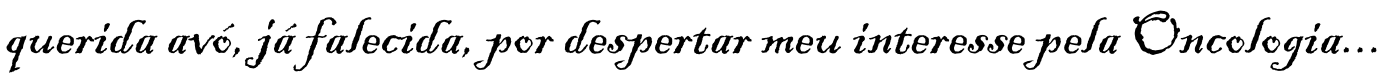

花ima de tudo, dedico este trabasho aos animais, que são a grande fonte de inspiração em minfia vida! Meu amor incondicional à efes, seres divinos, é o que me motiva a superar desafios, ir atrás de meus objetivos, fuscando sempre aprimorar meus confiecimentos.

Pinto-me na obrigação de fazer a cada dia o melfior por eles... 


\section{Agradecimentos}

Agradeço primeiramente a Deus, pela oportunidade que tive de realizar um dos sonhos de minha vida. ... Obrigada!

Fui abençoada durante este período de meu mestrado pois foram muitas as pessoas que apareceram no meu caminho para me ajudar e acrescentaram muito ao meu projeto!

Aos meus colegas do laboratório: Lucas, Ivone, Prof. Bruno (que sempre mostrou-se disponível para me ajudar), Teresa, Fabrizio (obrigada pelas dicas e paciência !!), André, Nathalia, Katia (que me ajudou muito enquanto ainda estava aqui), assim como outros colegas do departamento como a Luciana, que contribuiu na coleta de material e interpretação de resultados ! Gabi, obrigada também pela ajuda e boa vontade !! Todos me ajudaram com sua experiência, competência, paciência e apoio! Muito obrigada! Sem vocês não teria chegado até aqui!

Ao meu colega Marcello, companheiro de mestrado, por todo seu apoio! Compartilhamos juntos os momentos bons e os mais difíceis, mas nunca desistimos!!

Faço um agradecimento em especial à Profa Cristina Massoco, uma pessoa maravilhosa que conheci durante minha vida profissional e tive a honra de encontrála novamente neste período. Além de sempre me incentivar, mostrou-se interessada em ajudar-me a superar as dificuldades ao longo deste projeto (foram tantas idéias!) !! Não tenho palavras para agradecer !!

Ao Provet, em especial aos doutores Rubem e Edgar, que disponibilizaram o material para este projeto, e à toda equipe de patologia, especialmente à Jana, Débora, Thaís, Lissandro e os técnicos do laboratório! Agradeço principalmente pelo carinho, atenção e disposição de vocês!

À equipe do laboratório Vetmol, que me auxiliou nas reações de imunoistoquímica. Obrigada Rafael por toda sua atenção, disponibilidade e agilidade neste fim de projeto; obrigada pelo auxílio e principalmente por sua paciencia! E à Profa. Renee, que além de todo auxílio, me convidou para um almoço junto ao Dr Matti Kiupel, no evento de abril/14! Nunca vou esquecer! Oportunidade única em minha vida! E agradeço ao Dr Kiupel também, pelo contato, pelas idéias e interesse em meu projeto! 
Agradeço enormemente à equipe do laboratório Histopet, em especial ao Emerson e à Priscila! Obrigada Emerson, por sua atenção, dedicação e por todo auxílio neste período! A ajuda de vocês foi de grande valia!

Ao Ernesto, que me auxiliou com toda parte estatística deste projeto! Obrigada pela sua disponibilidade neste período em que você também estava com seus compromissos, mas ainda assim mostrou-se muito solícito. Obrigada por seus ensinamentos!

Aos colegas da Universidade Anhembi-Morumbi, que também contribuíram com material para este estudo. Agradeço o apoio do Prof Guerra, assim como à minha querida amiga Adriana, que me ajudou muito não só na coleta de amostras mas também com seu apoio, confiança e amizade!

Ao Felipe Sueiro do laboratório Vetpat, pelas idéias e sugestões, assim como pela disponibilização de materiais.

Ao meu colega Tarso, pelos conselhos e por me apresentar o laboratório antes mesmo deste projeto. Obrigada por toda sua ajuda neste período!

Às minhas queridas amigas de Pirassununga!! Obrigada especialmente à Camila e Lídia pela ajuda e apoio em muitos momentos ao londo deste projeto!!

Em especial aos meus queridos amigos que ajudaram na coleta de material!! Obrigada à toda equipe de Oncologia do Provet! Obrigada Karine e Suzana e Fernanda pelos muitos mastocitomas, mas obrigada principalmente ela amizade de vocês!! Obrigada Márcia e toda equipe de anestesiologia !! Obrigada Eduardo e Vanessa, por também terem contribuído para a coleta de material neste projeto!

Aos funcionários da biblioteca da FMVZ-USP, sempre disponíveis e solícitos para nos auxiliar.

Aos pacientes e proprietários, que contribuíram para a realização deste projeto!

À minha familia e especialmente ao meu namorado João Paulo e meus " filhos", pelo apoio e incentivo incondicionais neste período. Agradeço pela compreensão dos meus momentos de ausência e principalmente pela paciência! Obrigada por ter vocês ao meu lado! Obrigada Zeca e Suzy pela companhia ao longo das noites em frente ao computador! 
À todos meus amigos e aqueles que não foram aqui citados, mas que de alguma forma contribuíram para eu seguir adiante e que serviram de inspiração para eu alcançar meus objetivos.

Ao CNPq pelo apoio financeiro com bolsa durante este projeto. 


\section{AGRADECIMENTOS ESPECIAIS}

Faço agradecimento muito especial à Marguiti! Obrigada por toda sua ajuda com o processamento do material para este projeto. Obrigada pela paciência e por tudo que tive a oportunidade de aprender com sua experiencia! Quando cheguei no laboratório, me sentia como um peixe for a d'água, mas graças a você, e claro, ao Daniel, logo me familiarizei com tudo! Nunca esquecerei estes ensinamentos!

À Carol e ao Daniel !! Meu agradecimento à vocês é mais do que especial! Agradeço pelo material cedido, pela disponibilidade de vocês, pela paciência !!! Nossa, nem sei como agradecer pela paciência !!! Sempre muito solícitos, me deram dicas preciosas! Realmente, obrigada é pouco para vocês... mas acima de tudo, queria agradecer à vocês pela amizade! Duas pessoas maravilhosas que entraram na minha vida!

À Karen pelos dias, tardes e noites de companheirismo no laboratório! Foram muitos chás e cafezinhos juntas! Te agradeço pelo apoio, incentivo e ajuda com toda sua experienia profissional neste meu projeto! Acima de tudo, obrigada por sua amizade!

À Greice pelas coletas, por seu apoio e principalmente pela nossa amizade!! Agradeço por saber que sempre podia contar com você!! Isso fez toda a diferença para que eu pudesse seguir adiante com meu projeto! 
Obrigada Rodrigo! Primeiramente, por sua amizade !! E claro, pela coleta de grande parte do material utilizado neste projeto; serei sempre grata por isto!! Agradeço também pela confiança que depositou em mim e principalmente pelo incentivo e apoio incondicionais!!!! E pela compreensão e paciência neste período! Sinta-se parte desta minha conquista pois você sempre foi e será uma pessoa que admiro muito e uma pessoa em quem me inspiro !! Obrigada de coração Ro !!!

Faço agora um agradecimento em especial à minha querida orientadora, Profa Dra Maria Lucia Zaidan Dagli! Uma das pessoas que mais admiro nesta vida! Sinto-me honrada pela oportunidade que tive de ser orientada por você! Lembro de nossas conversas da época em que ainda estava na graduação, mas já buscava seguir seus conselhos. E assim fiz, começando pelo meu estágio na França, até chegar no Mestrado. Agradeço pelo apoio e incentivo desde sempre, mas agradeço principalmente pela confiança na minha pessoa. Meu respeito e admiração por você, não só como profissional, mas também como pessoa, não tem tamanho! 
"O êxito da vida não se mede pelo caminho que você conquistou, mas sim pelas dificuldades que superou no caminho"

(Abraham Lincoln) 


\section{RESUMO}

CIRILLO, J. V. Avaliação citológica e histopatológica de linfonodos regionais em cães portadores de mastocitomas de graus 1, 2 ou 3 e sua importância na determinação da sobrevida. [Cytological and histopathological evaluation of regional lymph nodes in dogs with grade 1,2 or 3 mast cell tumors and their importance in determining survival]. 2015. 166 f. Dissertação (Mestrado em Ciências) - Faculdade de Medicina Veterinária e Zootecnia, Universidade de São Paulo, São Paulo, 2014.

Mastocitomas são neoplasias muito prevalentes em cães, e podem ser classificados em graus 1, 2 ou 3 de acordo com características morfológicas. O objetivo deste projeto foi investigar a presença de metástases de mastocitomas caninos de graus 1, 2 ou 3 em linfonodos regionais, procurando correlaciona-las ao intervalo livre de doença e à sobrevida dos animais. Para isto, avaliamos os parâmetros clínicos dos animais e das neoplasias em 57 cães portadores de mastocitoma cutâneo, registrando-se a porcentagem dos casos que apresentaram metástases, o grau histológico da neoplasia e a sobrevida dos animais. Realizou-se análise citológica dos linfonodos regionais previamente ao procedimento cirúrgico e posteriormente estes linfonodos foram excisados junto com a neoplasia primária, independentemente do resultado da citologia. Os tumores foram graduados por histopatologia e submetidos à análise imunoistoquímica com c-kit e Ki-67. Os linfonodos foram avaliados por histopatologia, por análise histoquímica e por imunoistoquímica com c-kit. Foi realizada comparação entre o diagnóstico citológico e histopatológico dos linfonodos quanto à presença de metástases e entre fatores prognósticos associados à neoplasia e a presença de metástase em linfonodo. A citologia demonstrou ser um bom exame na detecção de metástase em linfonodo de cães portadores de mastocitoma cutâneo, e foram observadas células metastáticas em 36 casos (36/46). Na análise histológica dos linfonodos, observamos um maior índice de metástase nos animais diagnosticados com mastocitomas de grau 3, segundo a graduação de Patnaik, e com mastocitomas de alto grau, segundo a graduação de Kiupel. No entanto, não encontramos uma associação significativa entre a presença de metástase em linfonodo e o grau histológico da neoplasia. $\mathrm{O}$ grau histológico associou-se à sobrevida independentemente da presença de metástase em linfonodo. Não houve associação entre o padrão de expressão da proteína KIT na neoplasia com a presença de metástase em linfonodo, nem a 
sobrevida. A utilização da imunoistoquímica em linfonodos metastáticos com c-kit foi um método eficaz, com predomínio do mesmo padrão de marcação da proteína KIT na neoplasia primária e no linfonodo. A expressão de Ki-67 na neoplasia correlacionou-se à presença de metástase em linfonodo e à uma menor sobrevida e intervalo livre de doença nos animais que apresentavam mastocitomas com índice de Ki-67 acima de 23. $\mathrm{Na}$ análise da sobrevida, não observamos diferença na sobrevida, nem no intervalo livre de doença, comparando-se os animais que apresentavam metástase em linfonodo e aqueles que não apresentavam, entretanto o índice de óbito e de progressão da doença neste estudo foram baixos. O intervalo livre de doença e sobrevida média não foram alcançados ao final do estudo. Os resultados sugerem que a presença de metástase em linfonodo não deve ser considerada como um fator prognóstico independente em cães diagnosticados com mastocitoma cutâneo, uma vez que outros fatores prognósticos, bem como a utilização de tratamentos adjuvantes, podem interferir de forma significativa na evolução destes pacientes.

Palavras-chave: Mastocitoma. Cutâneo. Canino. Linfonodo. Metástase. 


\begin{abstract}
CIRILLO, J. V. Cytological and histopathological evaluation of regional lymph nodes in dogs with grade 1, 2 or 3 mast cell tumors and their importance in determining survival. [Avaliação citológica e histopatológica de linfonodos regionais em cães portadores de mastocitomas de graus 1,2 ou 3 e sua importância na determinação da sobrevida]. 2015. 166 f. Dissertação (Mestrado em Ciências) Faculdade de Medicina Veterinária e Zootecnia, Universidade de São Paulo, São Paulo, 2014.
\end{abstract}

Mast cell tumors are very prevalent in dogs, and can be classified in grades 1, 2 or 3 according to morphological characteristics. The aim of this study was to investigate the presence of metastases in regional lymph nodes of grade 1, 2 or 3 canine mast cell tumors, and correlate its presence to the disease-free interval and survival of the animals. For this, we evaluated the clinical parameters of animals and tumors in 57 dogs with cutaneous mast cell tumor, registering the percentage of cases with metastasis, histological grade of the tumor and survival of the animals. Cytological analysis of regional lymph nodes were performed prior to surgery and then these lymph nodes were excised along with the primary tumor, regardless of the result of cytology. The tumors were graded by histopathology and submitted to immunohistochemical analysis with c-kit and Ki-67. The lymph nodes were evaluated by histopathology, histochemistry and immunohistochemistry with c-kit. We compared the cytological and histopathological diagnosis of lymph nodes for the presence of metastases and compared prognostic factors associated with the primary tumor and the presence of metastasis in lymph node. Cytology proved to be a good method in detecting lymph node metastasis in dogs with cutaneous mast cell tumors and metastatic cells were observed in 36 cases (36/46). In the histological analysis of the lymph nodes, we observed a higher rate of metastasis in animals diagnosed with grade 3 mast cell tumors, according to the Patnaik grading system, and with high-grade mast cell tumors, according to the Kiupel grading system. However, we have not found a significant association between the presence of metastasis in lymph nodes and the histological grade of the tumors. Histological grade associated with survival independent of the presence of lymph node metastasis. In addition, there was no association between the pattern of KIT protein expression in the primary tumor and lymph node metastasies or survival. The use of immunohistochemistry in metastatic lymph nodes with c-kit is an effective method, 
with prevalence of the same KIT pattern in primary tumor and lymph node. The expression of Ki-67 in the primary tumor correlated with lymph node metastasis, survival and disease-free-time, and it was observed in animals in which mast cell tumors had a Ki-67 index higher than 23. In survival analysis, we observed no difference in survival or in disease-free interval, comparing the animals with lymph node metastasis and those who did not had, though the death rate and disease progression in this study were low. The disease-free interval and median survival were not reached at the end of the study. The results suggest that the presence of lymph node metastasis should not be considered as an independent prognostic factor in dogs diagnosed with cutaneous mast cell tumors, since other prognostic factors, as well as the establishment of adjuvant treatment, can interfere significantly with the progression of these patients.

Keywords: Mast cell tumor. Canine. Lymph node. Metastasis. 


\section{LISTA DE ILUSTRAÇÕES}

Figura 1 - Esquema proposto para o diagnóstico do mastocitoma cutâneo canino

Figura 2 - Fotomicrografias dos padrões de marcação imunoistoquímica do KIT, com contracoloração com hematoxilina

Figura 3 - Fotomicrografias dos padrões de marcação imunoistoquímica com Ki-67, com contracoloração com hematoxilina

Figura 4 - Fotomicrografia da coloração histoquímica pelo azul de toluidina ....102

Figura 5 - Fotomicrografia da coloração histoquímica pelo aldeído-fucsina de Gomori.

Figura 6 - Fotomicrografia da marcação imunoistoquímica do KIT e da coloração histoquímica pelo azul de toluidina em linfonodo

Figura 7 - Fotomicrografia da marcação imunoistoquímica do KIT e da coloração histoquímica pelo azul de toluidina em linfonodo

Figura 8 - Curva de Kaplan-Meier de análise de sobrevida nos pacientes com e sem metástase em linfonodo.

Figura 9 - Curva de Kaplan-Meier de análise de sobrevida nos pacientes com e sem metástase em linfonodo.

Figura 10 - Curva de Kaplan-Meier de análise de sobrevida dos pacientes segundo a graduação histológica de Patnaik.

Figura 11 - Curva de Kaplan-Meier de análise do intervalo livre de doença dos pacientes segundo a graduação histológica de Kiupel.

Figura 12 - Curva de Kaplan-Meier de análise de sobrevida segundo a graduação histológica de Kiupel.

Figura 13 - Curva de Kaplan-Meier de análise do intervalo livre de doença segundo a graduação histológica de Kiupel 
Quadro 1 - Estadiamento clínico dos mastocitomas segundo a Organização Mundial da Saúde

Quadro 2 - Critérios citológicos utilizados proposto pelo Serviço de Patologia Clínica do Hospital Veterinário Matthew J. Ryan, da Universidade da Pensilvânia para a determinação de metástase de mastocitoma em linfonodos regionais .

Quadro 3 - Novo sistema de classificação para avaliação microscópica de metástase em linfonodo em cães com mastocitoma..........................48

Quadro 4 - Características clínicas dos pacientes 96

Quadro 5 - Distribuição dos dados das neoplasias, linfonodos e evolução clínica dos animais avaliados no estudo 


\section{LISTA DE TABELAS}

Tabela 1 - Descrição das variáveis e seus efeitos na sobrevida (Modelo não ajustado).

Tabela 2 - Descrição das variáveis graduação histológica de Kiupel e Ki-67 e seus efeitos na sobrevida (Modelo ajustado)

Tabela 3 - Descrição das variáveis e seus efeitos na sobrevida (Modelo não ajustado)

Tabela 4 - Descrição das variáveis graduação histológica de Kiupel e Ki-67 e seus efeitos na sobrevida (Modelo ajustado) 


\section{SUMÁRIO}

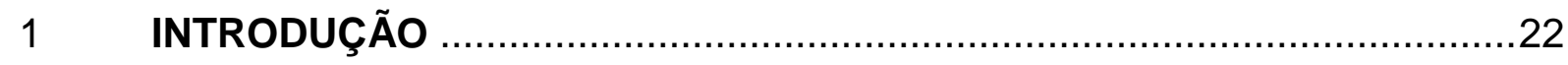

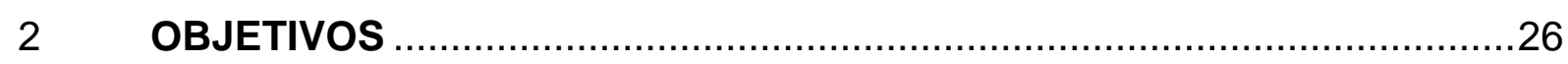

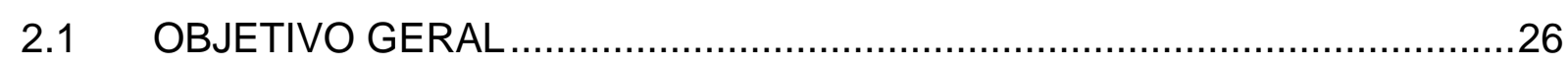

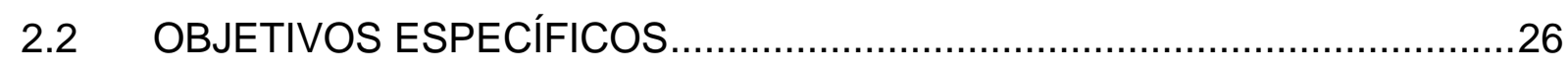

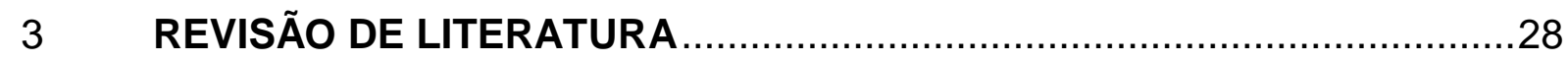

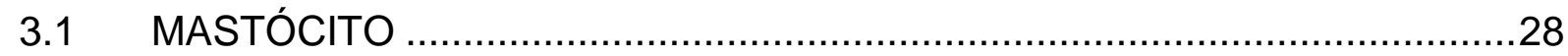

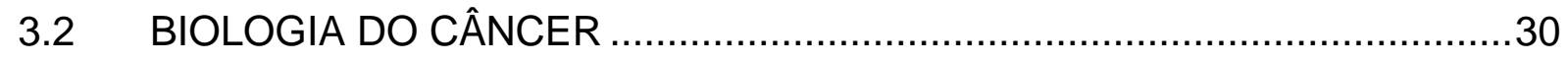

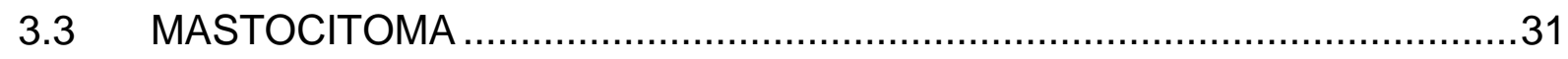

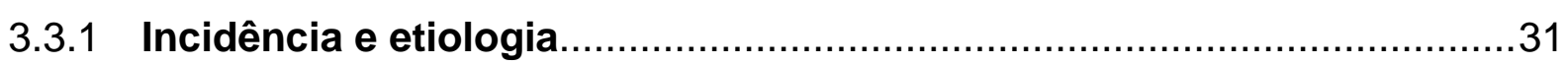

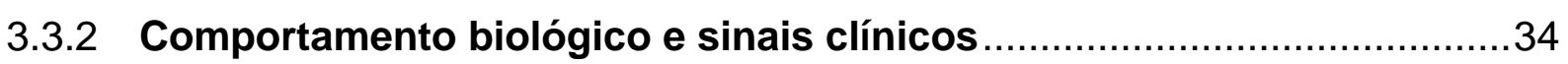

3.3.3 Diagnóstico e características histopatológicas .....................................36

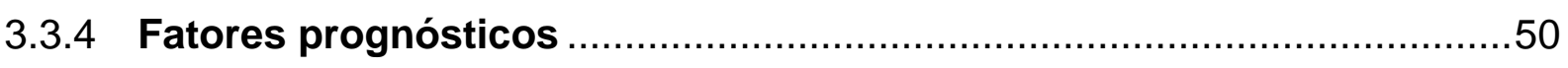

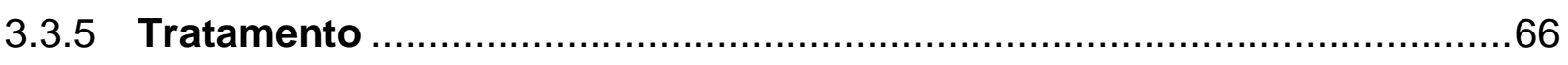

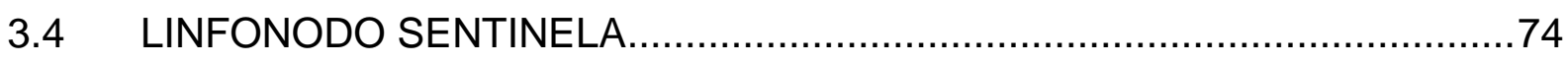

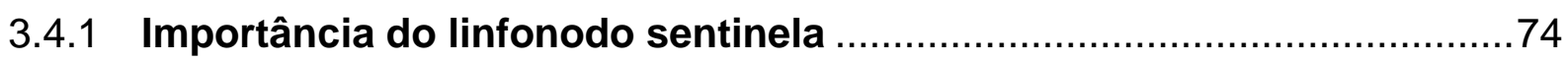

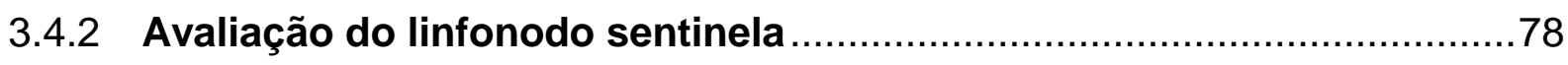

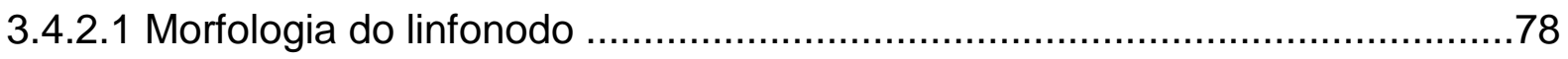

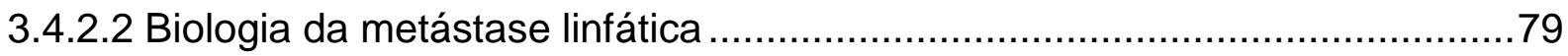

3.4.2.3 Métodos de avaliação do linfonodo sentinela...........................................80

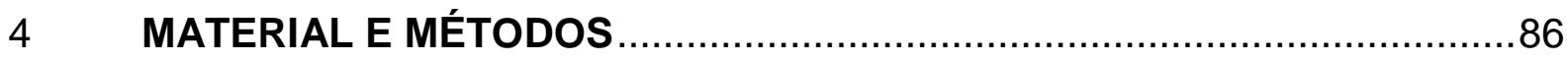

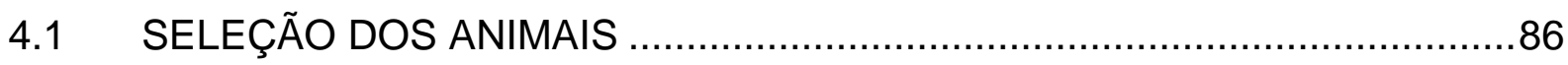

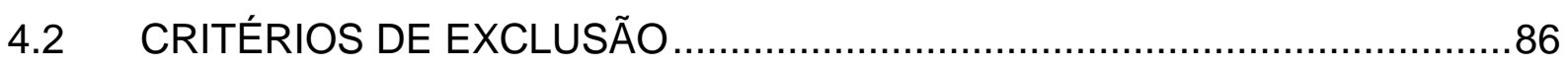

4.3 PROCEDIMENTOS CLÍNICOS E CIRÚRGICOS ESTABELECIDOS ............87

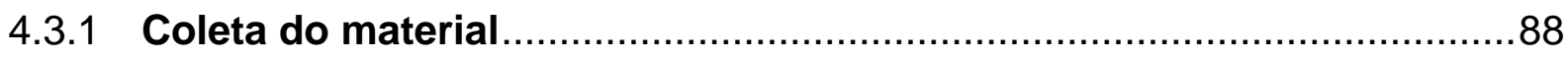

4.4 PROCESSAMENTO E GRADUAÇÃO HISTOPATOLÓGICA .......................88

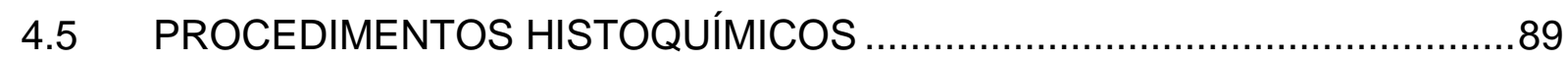

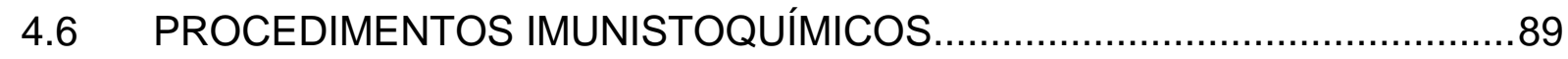

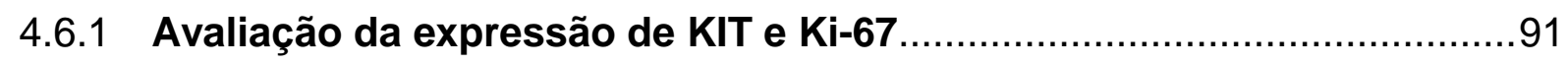

4.7 EVOLUÇÃO DOS CASOS CLÍNICOS...................................................

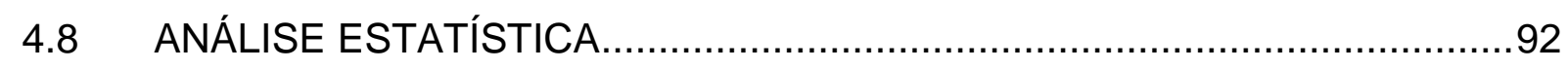

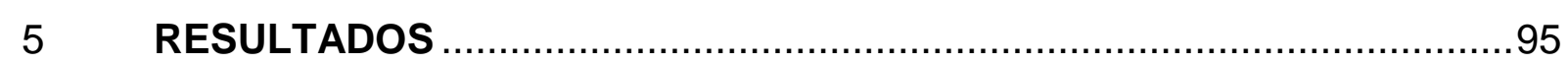




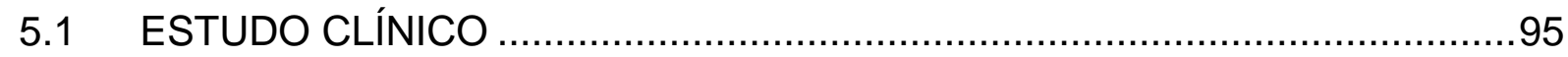

5.2 CLASSIFICAÇÃO HISTOPATOLÓGICA DOS MASTOCITOMAS ….............96

5.3 MARCADORES IMUNOISTOQUÍMICOS DOS MASTOCITOMAS ................98

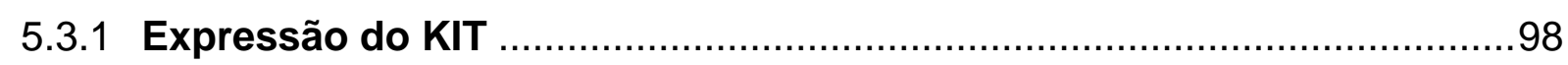

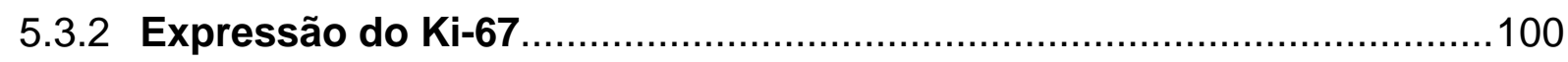

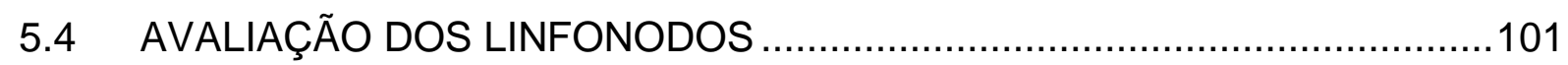

5.5 EVOLUÇÃO DOS CASOS CLÍNICOS....................................................104

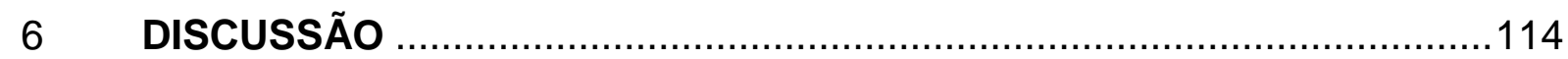

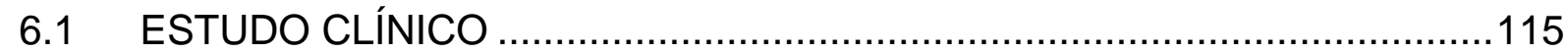

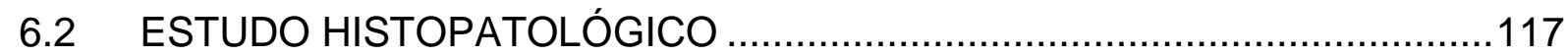

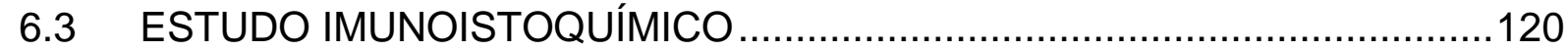

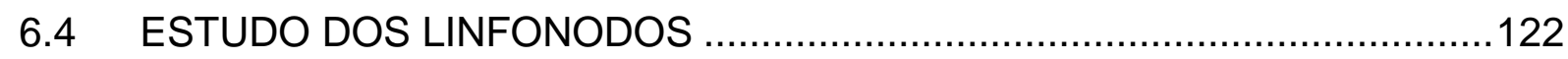

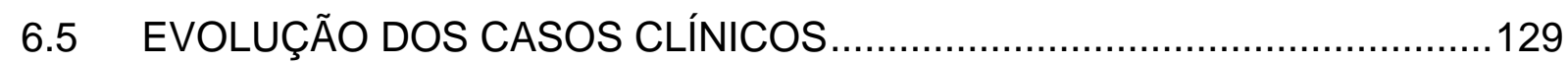

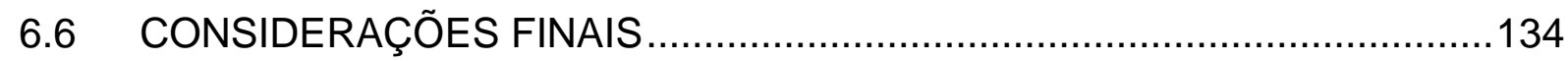

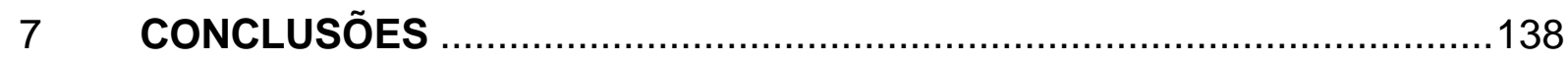

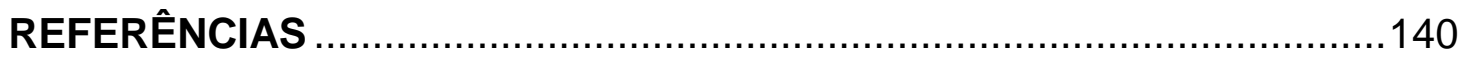




\section{INTRODUÇÃO}

Neoplasias cutâneas e subcutâneas são as mais prevalentes em cães, representando cerca de um terço da incidência geral de neoplasias. Dentre as neoplasias cutâneas malignas, o mastocitoma é aquela que ocorre com maior frequência nos cães, abrangendo 16 a $21 \%$ dos tumores cutâneos (FINNIE; BOSTOCK, 1979; BOSTOCK, 1986; ROTHWELL et al., 1987). Em um estudo realizado em 2012, Kimura et al, 2012, constataram que os mastocitomas caninos representaram 7\% de todas as neoplasias diagnosticadas em animais entre $1993 \mathrm{e}$ 2002 no Serviço de Patologia Animal do Departamento de Patologia da Faculdade de Medicina Veterinária e Zootecnia da USP,

A apresentação clínica dos mastocitomas é variada, podendo ocorrer sob a forma de um nódulo único ou múltiplas lesões (TAMS; MACY, 1981). O potencial metastático desta neoplasia varia de acordo com sua classificação histopatológica, ocorrendo em menos de $10 \%$ dos casos nos mastocitomas bem diferenciados, em 5 a $22 \%$ das neoplasias moderadamente diferenciadas e em 55 a $96 \%$ dos casos nos mastocitomas pouco diferenciados (BOSTOCK, 1973; WEISSE; SHOFER; SORENMO, 2002; MURPHY et al., 2004; MULLINS et al., 2006; HUME et al., 2011). As metástases ocorrem principalmente para os linfonodos loco-regionais, podendo acometer posteriormente baço e fígado (O'KEEFE, 1990; LEMARIÉ, 1995), ou outros órgãos. Diversos autores sugerem que pacientes com mastocitoma de qualquer grau e que tenham envolvimento de linfonodo regional, possuem maior risco de óbito decorrente da doença (TURREL et al., 1988; AYL et al., 1992; GERRITSEN et al., 1998; THAMM; MAULDIN; VAIL, 1999; THAMM; VAIL, 2003).

O diagnóstico desta neoplasia pode ser obtido por meio de citologia aspirativa da lesão primária, mas a correta determinação de sua graduação é realizada por análise histopatológica. Dentre outros exames, a citologia aspirativa do linfonodo regional deve fazer parte do estadiamento da doença, com o objetivo de investigar a presença de metástase no mesmo. De acordo com a literatura, a identificação da presença de metástase em linfonodo em cães com diagnóstico de mastocitoma é considerada um fator prognóstico negativo e tem um impacto direto na evolução clínica da doença e na conduta terapêutica (THAMM; MAULDIN; VAIL, 1999; 
GIEGER et al., 2003; MURPHY et al., 2006; THAMM et al., 2006; MARCONATTO et al., 2008; KRICK et al., 2009; HUME et al., 2011; BLACKWOOD et al., 2012; WORLEY, 2012; WEISHAAR et al., 2014 (no prelo) ${ }^{1}$ ). Uma vez diagnosticada a metástase, recomenda-se a exérese do linfonodo regional cirurgicamente ou a realização de tratamento radioterápico local (THAMM; TUREK; VAIL, 2006; BAGINSKI; DAVIS; BASTIAN, 2014). Segundo Chaffin e Thrall (2002), Hume et al. (2011) e Baginski et al. (2014), animais que receberam tratamento do linfonodo metastático apresentaram maior sobrevida em relação aqueles não tratados.

A importância da avaliação da presença de metástase em linfonodo sentinela já é bem estabelecida em diversas neoplasias humanas, no entanto, esta prática não é rotineiramente realizada na oncologia veterinária. Tuohy et al. (2009) consideraram que o status dos linfonodos regionais ou sentinelas é importante para a predição da sobrevida, informando ainda, que a identificação e biópsia dos linfonodos sentinelas são importantes para o estadiamento de neoplasias, auxiliando na determinação do prognóstico e na escolha pela melhor conduta terapêutica.

Krick et al. (2009) realizaram estudo de coorte retrospectivo para descrever a associação entre a avaliação citológica das metástases em linfonodos com a sobrevivência em cães portadores de mastocitoma cutâneo. Os resultados do estudo sugeriram que a avaliação citológica dos linfonodos em cães com mastocitomas caninos correlacionou com o grau do tumor e com a sobrevida, sendo, portanto, considerada um método prático e não invasivo de estadiamento. Entretanto, neste estudo não foi realizada comparação entre as informações obtidas do exame citológico com o exame histopatológico.

Devido à pouca prática da investigação de linfonodos regionais em cães portadores de mastocitoma cutâneo, este projeto buscou avaliar os seguintes dados: análise citológica e histopatológica dos linfonodos, determinando a sensibilidade e especifidade do exame citológico no diagnóstico de metástase; utilização de técnicas de histoquímica com o azul de toluidina e aldeído-fucsina de Gomori para evidenciar a presença de mastócitos nos linfonodos; avaliação dos padrões de metástase nos linfonodos; avaliação da presença de metástase em linfonodo de acordo com o grau histológico da neoplasia primária; avaliação da expressão das

\footnotetext{
${ }^{1}$ WEISHAAR, K. M.; THAMM, D. H.; WORLEY, D. R.; KAMSTOCK, D. Correlation of nodal mast cells with clinical outcome in dogs with mast cell tumour and a proposed classification system for the evaluation of node metastasis. Journal of Comparative Pathology. (Aceito para publicação em 2014).
} 
proteínas KIT e Ki-67 nas neoplasias primárias, correlacionando-as à presença de metástase em linfonodo e análise da sobrevida e intervalo livre de doença nos animais com e sem presença de metástase em linfonodo.

Esperamos com este estudo fornecer dados mais precisos quanto a importância da avaliação do linfonodo sentinela em animais portadores do mastocitoma cutâneo, podendo incorporar estes procedimentos à rotina em oncologia veterinária. 


\section{OBJETIVOS}

\subsection{OBJETIVO GERAL}

O objetivo geral deste trabalho é avaliar a presença de metástases de mastocitomas cutâneos caninos em linfonodos regionais por exames citológico e histopatológico e verificar sua correlação com a sobrevida.

\subsection{OBJETIVOS ESPECÍFICOS}

- determinar as características clínicas dos animais portadores de mastocitomas

- determinar a graduação histopatológica dos mastocitomas, utilizando os métodos propostos por Patnaik e Kiupel.

- avaliar a presença de metástase nos linfonodos através das colorações histoquímicas aldeído-fucsina de Gomori e azul de toluidina.

- verificar a presença de metástases dos mastocitomas nos linfonodos regionais, classificando-as segundo Weishaar et al. (2014) (no prelo) ${ }^{2}$.

- comparar a eficácia do exame citológico em relação ao histopatológico na detecção de metástase nos linfonodos regionais.

- determinar a localização da expressão da proteína KIT e seu padrão de marcação nas neoplasias primárias e nos linfonodos por imunoistoquímica.

- determinar a quantidade de núcleos marcados com Ki-67 nas neoplasias primárias por imunoistoquímica.

- associar estas variáveis a fim de determinar a importância da presença de metástase em linfonodos regionais de mastocitomas caninos na sobrevida.

\footnotetext{
${ }^{2}$ WEISHAAR, K. M.; THAMM, D. H.; WORLEY, D. R.; KAMSTOCK, D. Correlation of nodal mast cells with clinical outcome in dogs with mast cell tumour and a proposed classification system for the evaluation of node metastasis. Journal of Comparative Pathology. (Aceito para publicação em 2014).
} 


\section{REVISÃO DE LITERATURA}

\subsection{MASTÓCITO}

Mastócitos são células de origem hematopoiética, sendo derivadas de células progenitoras CD34(+), CD13(+) e CD117(+) (ou KIT). Estas células são liberadas na corrente sanguínea ainda imaturas, migrando para o tecido conjuntivo, derme, pulmões, lâmina própria das mucosas e regiões perivasculares onde terminam sua maturação, acumulando grânulos citoplasmáticos e proliferam mediante estímulos (GILFILLAN; TKACZYK, 2006; KIERSZENBAUM, 2008). Existem dois subtipos de mastócitos descritos: os mastócitos de mucosa (MM) e os mastócitos de tecido conjuntivo (MTC). Embora tenham o mesmo precursor celular, o que distingue estas células são suas características estruturais, bioquímicas e funcionais. MM localizamse predominantemente no intestino e pulmão, geralmente próximos a linfócito T. Já os MTC predominam na pele e no tecido subcutâneo.

Uma das principais características desta célula em todas as espécies, é a presença dos grânulos citoplasmáticos, que contêm substâncias bioativas, como a heparina, histamina, algumas citocinas (interleucina-6 [IL-6], fator de necrose tumoral-a [TNF- $\alpha]$ ), proteases e fator de crescimento de fibroblastos. Já os leucotrienos, como os metabólitos do ácido araquidônico, são produtos vasoativos dos mastócitos, mas não estão presentes nos grânulos, sendo liberados a partir da membrana plasmática da célula. A superfície dos mastócitos expressa receptores para a imunoglobulina $\mathrm{E}(\mathrm{lgE})$, FcعRI, que mediante à ligação de um antígeno, sensibiliza o mastócito às moléculas de $\operatorname{lgE}$ e o conteúdo de seus grânulos é rapidamente liberado por exocitose, num processo denominado degranulação ou desgranulação. A liberação destes produtos promove inflamação, causando vasodilatação, recrutamento e adesão de células, remodelamento e fibrose e angiogênese (KRISHNASWANY; AJITAWI; CHI, 2006; KIERSZENBAUM, 2008; KUMAR; SHARMA, 2010).

Os grânulos dos mastócitos possuem uma propriedade tintorial, conhecida como metacromasia. Quando corados com certos corantes azuis básicos, como o 
azul de toluidina, ligam-se a este, adquirindo uma coloração púrpura-avermelhada (YOUNG et al., 2007).

Mastócitos e seus precursores, no processo de desenvolvimento celular, expressam em sua superfície um receptor tirosina quinase (KIT), o qual possui um domínio de ligação extracelular, uma região transmembrânica e uma extremidade citoplasmática com atividade tirosina quinase (MEININGER et al., 1992; KRISHNASWANY; AJITAWI; CHI, 2006). Este receptor é codificado para o protooncogene $c$-kit e é ativado através de sua ligação com o fator de célula-tronco (SCF, stem cell fator), também conhecido como fator de crescimento de mastócito (ANDERSON et al., 1990) e esta ligação induz o processo de dimerização do KIT e subsequente fosforilação, gerando sinais intracelulares que promovem a proliferação, diferenciação e maturação dos mastócitos (GALLI; ZSEBO; GEISSLER, 1994).

Morfologicamente, mastócitos apresentam-se como células ovóides, medindo cerca de 20 a $30 \mu \mathrm{m}$, com núcleo pequeno, esférico e centralizado e um vasto citoplasma repleto de grânulos basofílicos (SAMUELSON, 2007).

Mastócitos podem ser identificados por imunoistoquímica por meio da expressão do receptor KIT e da triptase, uma das principais proteases presente nestas células (WALLS et al., 1990).

Desde que foram descritos pela primeira vez em 1878 por Paul Ehrlich, uma das funções mais conhecidas dos mastócitos é a sua participação em reações alérgicas. No entanto, atualmente sabe-se que estas células estão envolvidas também em outros processos fisiológicos e patológicos. Sua maturação, fenótipo e função estão diretamente relacionados ao seu microambiente e tem uma influência direta na sua habilidade de reconhecimento e resposta a vários estímulos, através da liberação de mediadores biologicamente ativos. Por isso, participam tanto da resposta imune inata, como da resposta imune adaptativa (DA SILVA; JAMUR; OLIVER, 2014). 


\subsection{BIOLOGIA DO CÂNCER}

Segundo Evans (1993), "os cânceres são consequências de alterações genéticas e epigenéticas envolvendo uma variedade de genes que são fundamentais para os processos de crescimento e diferenciação celulares, e para a remoção celular programada". Estas alterações podem ser causadas por fatores intrínsecos (herdáveis ou não), como os radicais livres decorrentes de um processo inflamatório crônico, e/ou fatores extrínsecos, como por exemplo carcinógenos ambientais, agentes infecciosos ou mesmo a dieta. Muitas mutações podem ser silenciosas, não interferindo na função celular. Entretanto, algumas mutações promovem a ativação de proto-oncogenes ou inibem a ação de genes supressores tumorais, favorecendo a proliferação e sobrevivência da célula. Atualmente sabe-se que a interação entre genes e fatores ambientais têm um impacto direto na origem, progressão e resposta à terapia em diversas neoplasias (PONDER, 2001; MODIANO, 2013). Vale ressaltar que além dos eventos que levam a mutações no DNA, as alterações epigenéticas também estão relacionadas ao desenvolvimento do câncer. Alterações epigenéticas são herdáveis, mas potencialmente reversíveis e promovem uma mudança na expressão gênica, ou seja, são eventos capazes de alterar o fenótipo sem que haja modificação do genótipo. As principais alterações epigenéticas descritas estão relacionadas a metilação do DNA e conformação da cromatina, além da expressão de micro RNAs (CHENG; JONES, 2005; MODIANO, 2013).

Há 14 anos atrás, Hanahan e Weinberg (2000) descreveram seis características adquiridas pela célula tumoral durante 0 processo de desenvolvimento das neoplasias, que incluem: capacidade de manutenção da proliferação celular, capacidade de evasão de mecanismos supressores da proliferação celular, capacidade de resistir a apoptose, potencial replicativo ilimitado, capacidade de indução da angiogênese e capacidade de invasão e metástase. Estas características adquiridas são observadas em diversos tipos de tumores, via mecanismos distintos e em diferentes momentos durante 0 processo de tumorigênese, culminando na sobrevivência, proliferação e disseminação das células neoplásicas. Estes mesmos autores, em 2011, identificaram mais quatro características: instabilidade genômica e mutação, promoção da inflamação, 
reprogramação do metabolismo energético e evasão do sistema imunológico. Além das características supracitadas das células neoplásicas, o microambiente tumoral também exerce um importante papel no processo de tumorigênese, a partir da modulação das células que compõem o estroma tumoral, que favorecem o crescimento da neoplasia provendo uma matriz adequada, com abundância de nutrientes. Células tronco tumorais, células endoteliais, pericitos, células inflamatórias, fibroblastos associados ao câncer e as células tronco e progenitoras do estroma tumoral foram reportadas como células que contribuem de diferentes formas para a biologia de diversas neoplasias, por possuem esta capacidade de modulação do microambiente tumoral (HANAHAN; WEINBERG, 2011).

\subsection{MASTOCITOMA}

\subsubsection{Incidência e etiologia}

O mastocitoma é a neoplasia cutânea maligna mais frequente em cães, representando cerca de $16-21 \%$ dos tumores. Apesar de ser uma doença observada principalmente em animais idosos, com cerca de 8 a 9 anos de idade, existem relatos do acometimento de cães jovens, não havendo predisposição sexual observada cutâneos (FINNIE; BOSTOCK, 1979; BOSTOCK, 1986; ROTHWELL et al., 1987). Cole (1990) e Miller (1995) relataram a ocorrência de mastocitomas de grau 2 e 3 em um Pastor Alemão de 7 meses de idade e num Sharpei de 4 meses de idade, respectivamente. Mahler (2012) refere o diagnóstico de mastocitoma bem diferenciado em um cão da raça Boxer de 4 semanas de idade e sugere que mastocitomas devem ser considerados como um diagnóstico diferencial para formações cutâneas e subcutâneas em cães com menos de um ano de idade. Em um estudo retrospectivo de 280 cães portadores de mastocitoma, a idade no momento do diagnóstico variou entre 9 meses a 14 anos de idade, sendo que $91 \%$ dos cães apresentavam mais de 5 anos (MURPHY et al., 2004).

A predisposição racial no mastocitoma pode ser observada em diversas raças, principalmente naquelas descentes do Buldogue, como o Boxer, Boston 
Terrier, Buldogue Inglês e Pug, mas também em Labradores, Golden Retriever, Cocker Spaniel, Schnauzer, Staffordshire Terrier, Beagle, Rhodesian Rigebacks, Weimaraner, Sharpei e cães sem raça definida (PATNAIK; EHLER; MACEWEN, 1984; ROTHWELL et al., 1987; WHITE et al., 2011). Villamil et al. (2011) realizou um levantamento avaliando a distribuição racial em diversas neoplasias cutâneas em 25996 cães, incluindo o mastocitoma. As raças mais prevalentes foram cães sem raça definida, seguido por Boxer, Labrador e Golden Retriever.

Warland e Dobson (2013) realizaram um estudo retrospectivo com 222 cães diagnosticados com mastocitoma no Reino Unido entre 1997 e 2008. Semelhante ao estudo de Villamil et al. (2011), Boxer, Labrador, Golden Retriever e Staffordshire Terrier apareceram como as raças mais predispostas ao desenvolvimento de mastocitoma.

A incidência mais elevada desta neoplasia em determinadas raças sugere a possibilidade de uma etiologia genética, no entanto a etiopatogenia e os eventos moleculares genéticos que estão envolvidos no desenvolvimento e progressão do mastocitoma ainda não estão bem elucidados. Antigamente considerava-se que o desenvolvimento desta neoplasia estava associado à inflamação crônica ou à aplicação de substâncias irritantes à pele, mas a epidemiologia observada em cães não sustenta a hipótese de um carcinógeno tópico estar envolvido na etiologia do mastocitoma (LONDON; THAMM, 2013).

Em cães da raça Boxer, foi identificada a expressão de três sítios frágeis no cromossomo $\mathrm{X}$, uma alteração genética que tornaria esta raça mais predisposta ao desenvolvimento de neoplasias, incluindo o mastocitoma. No entanto, a população de cães do grupo controle incluía cães jovens não portadores de neoplasias (STONE et al., 1991).

Outras alterações genéticas que predispõem o animal ao desenvolvimento de mastocitoma foram estudadas. Alterações no gene supressor tumoral p53 foram identificadas em alguns estudos (GINN et al., 2000; JAFFE et al., 2000), mas Mayr et al. (1999) não encontrou mutação neste gene, apesar do número limitado de casos utilizado em seu estudo.

Wu et al. (2005) mostrou que a superexpressão da proteína Mdm2 tem um importante papel na tumorigênese do mastocitoma canino, sendo que sua expressão- correlacionou-se ao grau histológico da neoplasia. Em algumas neoplasias humanas, a co-expressão de Mdm2/p53 está associada à um 
comportamento mais agressivo do tumor e à um pior prognóstico, mas este estudo demonstrou que a expressão desta proteína é regulada por mecanismos independentes do gene p53.

Alterações na expressão das proteínas p27 e p21, que são inibidoras de ciclinas dependentes de quinase e contribuem para a regulação do ciclo celular, foi identificada em alguns mastocitomas caninos (WU et al., 2004).

Atualmente a alteração molecular mais bem descrita nos mastocitomas envolve o receptor KIT, que tem atividade de tirosina-quinase, responsável por desencadear a proliferação de mastócitos. London et al. (1996) identificou a expressão deste receptor em mastocitomas caninos, propondo que o receptor KIT tem um importante papel na etiologia desta neoplasia. O proto-oncogene c-kit codifica o receptor tirosina-quinase KIT (CD117). Diversas anormalidades como mutações pontuais, deleções e duplicações foram identificadas dentro do domínio justamembrana do gene c-kit (nos exons 11 e 12) e no domínio extracelular (envolvendo os exons 8 e 9). Estas mutações resultam na ativação contínua do receptor KIT independentemente de sua ligação com o SCF e subsequente desregulação da transdução de sinais do receptor KIT, resultando em proliferação e sobrevivência aberrante dos mastócitos, favorecendo o desenvolvimento da neoplasia (LONDON et al., 1999; DOWNING et al., 2002; PREZIOSI; MORINI; SARLI, 2004; LETARD et al., 2008).

Estudos mostram que cerca de $15-40 \%$ dos cães portadores de mastocitoma apresentam mutações principalmente no domínio justamembrana do gene c-kit e estas alterações estão associadas à progressão da doença, aumento no risco de recidiva, menor sobrevida e pior prognóstico (ZEMKE; YAMINI; YUZBASIYANGURKAN, 2002; LONDON; SEGUIN, 2003; WEBSTER et al., 2007).

Diversas estudos epidemiológicos em humanos apontam que a baixa concentração sérica de vitamina $D$ está associada à um aumento no risco do desenvolvimento de alguns tipos de câncer, como próstata, mama e colorretal (NG et al., 2008; TRUMP et al., 2009; YIN et al., 2009). Wakshlag et al. (2011) mostraram que a concentração sérica de vitamina $\mathrm{D}$, mensurada pelo $25(\mathrm{OH}) \mathrm{D} 3$, estava abaixo dos valores de referência em Labradores portadores de mastocitoma, quando comparados a Labradores hígidos, sugerindo que a alta incidência de mastocitoma nesta raça pode ter como possível etiologia a combinação de fatores genéticos agindo em resposta a fatores externos ou ambientais. 
Outras possíveis etiologias já propostas para o mastocitoma canino foram quadros de inflamação crônica, utilização de substâncias tópicas irritantes à pele ou mesmo uma etiologia viral, mas estudos epidemiológicos não comprovaram estas hipóteses (LONDON; TAHMM, 2013).

\subsubsection{Comportamento biológico e sinais clínicos}

O comportamento biológico do mastocitoma está relacionado diretamente ao grau de diferenciação das células neoplásicas. Lesões pequenas e com histórico de evolução lenta são mais consistentes com mastocitomas bem diferenciados. Já mastocitomas pouco diferenciados tendem a apresentar-se como lesões de crescimento rápido, muitas vezes ulceradas e acompanhadas de inflamação e edema ao redor (NORTH; BANKS, 2009). No entanto, em algumas raças o mastocitoma parece comportar-se de forma benigna, como reportado por McNiel et al. (2004). Neste estudo avaliaram-se 25 cães da raça Pug e observou-se que apesar do desenvolvimento de múltiplos mastocitomas, as neoplasias apresentaram um comportamento benigno. Davis et al. (1992) também relatam a regressão espontânea de múltiplos mastocitomas em um cão de 3 semanas de idade da raça Jack Russel Terrier.

O aspecto clínico desta neoplasia é bastante variado, apresentando-se como um nódulo único ou lesões múltiplas (em cerca de $3-25 \%$ dos casos), de consistência macia ou firme, podendo ou não ser alopécicas e eritematosas, mimetizando qualquer lesão cutânea. Acometem principalmente a derme e o tecido subcutâneo. Cerca de $50 \%$ dos casos localizam-se no tronco e região perineal, $40 \%$ em membros e aproximadamente $10 \%$ em região de cabeça e pescoço, apesar de existirem relatos desta neoplasia em conjuntiva, nasofaringe, laringe, glândula salivar, cavidade oral, ureter e medula espinhal (PATNAIK; EHLER; MACEWEN, 1984; MACY, 1985; O'KEEFE, 1990; SIMÕES; SCHONING; BUTINE, 1994; IWATA et al., 2000; DOBSON; SCASE, 2007; WELLE et al., 2008; NORTH; BANKS, 2009).

Os principais sinais clínicos associados ao mastocitoma são atribuídos à degranulação de mastócitos, onde há liberação de histamina, heparina e enzimas proteolíticas, que levam ao surgimento de úlceras gastroduodenais, coagulopatias e 
retardo no processo de cicatrização. A histamina estimula as células parietais do estômago através dos receptores $\mathrm{H} 2$, promovendo um aumento da secreção de ácido clorídrico e hipermotilidade gástrica, levando à ulceração gastroduodenal ou até mesmo perfuração gastrointestinal e peritonite. Pode-se observar quadro de anorexia, emese, hematoquesia, melena e dor abdominal. Howard et al. (1969) realizaram necropsia em 24 cães que vieram a óbito em decorrência de mastocitoma e destes, 20 apresentavam ulceração gastroduodenal, principalmente em região gástrica. Além disso, a liberação aguda de histamina e outras substâncias vasoativas pode levar a um quadro de hipotensão severa, hemorragias, choque e até mesmo óbito. Localmente, a degranulação manifesta-se por eritema e edema no tecido ao redor, conhecido por Sinal de Darier. A degranulação é mais frequente após a manipulação da neoplasia, como após um exame citológico ou mesmo durante o procedimento cirúrgico, podendo ocorrer espontaneamente também (FOX et al., 1990; BLACKWOOD et al., 2012).

Metástases ocorrem principalmente para os linfonodos regionais, assim como baço e fígado. Eventualmente, mastócitos neoplásicos podem ser observados na medula óssea, ou no sangue periférico, quando ocorre disseminação sistêmica da doença. Já comprometimento pulmonar raramente ocorre. O índice metastático varia conforme a graduação histopatológica e índices de proliferação da neoplasia, com $10 \%$ de metástase nos mastocitomas de grau $1,5-22 \%$ nos mastocitomas de grau 2 e $55-96 \%$ de metástase nos mastocitomas de grau 3, sendo em sua grande maioria, primeiramente para os linfonodos regionais (LEMARIE et al., 1995; WEISSE; SHOFER; SORENMO, 2002; CAHALANE et al., 2004; THAMM; VAIL, 2007; HUME et al., 2011). Bostock (1973) realizou um estudo onde cães portadores de mastocitoma foram avaliados no post-mortem por necropsia, e foi observado um índice de 7\%, 20\% e 82\% de metástase para linfonodos regionais em cães com mastocitomas bem diferenciados, moderadamente diferenciados e pouco diferenciados, respectivamente. Mastocitomas disseminam-se primeiramente para os linfonodos regionais e posteriormente para órgãos internos (LONDON; THAMM, 2013; WARLAND; DOBSON, 2013). 


\subsubsection{Diagnóstico e características histopatológicas}

Em 92-96\% dos casos, o diagnóstico desta neoplasia pode ser confirmado por citologia aspirativa com agulha fina (CAAF). Assim como outras neoplasias de células redondas, esfoliam com facilidade durante a coleta. Os mastócitos são facilmente identificados pelos seus grânulos de coloração púrpura intracitoplasmáticos característicos, na coloração de Romanowsky (BAKER-GABB; HUNT; FRANCE, 2003; BLACKWOOD et al., 2012). Cannas et al. (1994) afirmam que a coloração varia de acordo com o número e tamanho dos grânulos, assim como o grau de diferenciação da célula neoplásica. Mastocitomas pouco diferenciados possuem menor concentração de heparina e outros glicosaminoglicanos, que por sua vez interagem com os corantes histoquímicos. Por isso, em alguns casos pode ser necessário o uso de outras colorações, como o Azul de Toluidina, Giemsa ou Wright-Giemsa para evidenciar os grânulos, que adquirem uma coloração azulada ou arroxeada.

Para a correta graduação da neoplasia, o exame histopatológico se faz necessário. São descritos na literatura três principais sistemas de classificação para mastocitomas cutâneos caninos. O sistema proposto por Bostock avalia: razão núcleo:citoplasma, número de figuras de mitose, pleomorfismo celular, celularidade e metacromasia dos grânulos intracitoplasmáticos. Já o sistema proposto por Patnaik considera: morfologia celular, morfologia nuclear, índice mitótico, celularidade, extensão do envolvimento tecidual e reação estromal para determinar a graduação da neoplasia. Ambos os sistemas classificam os mastocitomas em 3 graus diferentes, entretanto a graduação de um sistema é inversa em relação ao outro. Mastocitomas bem diferenciados, são considerados de grau 1 por Patnaik, enquanto Bostock os considera como sendo de grau 3; já os mastocitomas moderadamente diferenciados são classificados como grau 2 por ambos os autores e aqueles pouco diferenciados, são classificados em grau 3 por Patnaik, e grau 1 por Bostock. Em ambos os sistemas de classificação, observou-se que os mastocitomas pouco diferenciados associavam-se à uma menor sobrevida, quando comparados às neoplasias moderadamente à bem diferenciadas (BOSTOCK, 1973; PATNAIK; EHLER; MACEWEN, 1984). O sistema proposto por Patnaik foi o mais comumente 
utilizado por patologistas nos Estados Unidos, na Europa e também no Brasil (STREFEZZI et al., 2003; MISDORP, 2004; BLACKWOOD et al., 2012).

Segundo Patnaik, Ehler e Macewen (1984), mastocitomas de grau 1 são compostos por fileiras ou agrupamentos de mastócitos monomórficos, bem diferenciados, com núcleo redondo, citoplasma distinto e amplo com grânulos de tamanho médio, sendo que as células neoplásicas estão confinadas à derme e espaços interfoliculares, não possuindo figuras de mitose nem reação estromal ou necrose. Já os mastocitomas de grau 2 possuem celularidade moderada à elevada, sendo compostos por mastócitos moderadamente pleomórficos, arredondados à ovalados, eventualmente exibindo células gigantes, com núcleo arredondado à indentado e citoplasma finamente granular, algumas vezes indistinto e com grânulos grandes e hipercromáticos, sendo que as células neoplásicas estendem-se à derme, subcutâneo e ocasionalmente em camadas mais profundas, como na musculatura esquelética ou tecidos adjacentes, apresentando 0-2 figuras de mitose por campo de maior aumento, exibido às vezes áreas de edema, necrose e estroma fibrocolagenoso com áreas de hialinização. Mastocitomas de grau 3 são altamente celulares e compostos por mastócitos pleomórficos, de formato arredondado, ovalado ou mesmo alongado, muitas vezes células gigantes são observadas, com núcleo vesicular arredondado à indentado e 1 a vários nucléolos proeminentes, exibindo também células binucleadas, com citoplasma indistinto com grânulos finos ou às vezes sem evidências de grânulos, sendo que as células neoplásicas estão dispostas em lençóis que substituem o tecido subcutâneo e os tecidos subjacentes, apresentando de 3-6 figuras de mitose por campo de maior aumento e contendo áreas de hemorragia, edema, necrose e colágeno hialinizado.

Apesar do histopatológico ser o principal fator prognóstico para o mastocitoma cutâneo canino, diversos trabalhos relatam uma variação entre patologistas na graduação desta neoplasia pelo sistema proposto por Patnaik, principalmente tratando-se dos mastocitomas de grau 2, que representam a maior parte dos casos. No estudo conduzido por Northrup et al. (2005), dez patologistas avaliaram 60 casos de mastocitoma em laminas histológicas coradas em hematoxilina-eosina (sendo 20 mastocitomas de grau 1, 20 de grau 2 e 20 de grau 3), sem o conhecimento prévio da graduação da neoplasia. Houve concordância entre todos os patologistas em apenas 4 dos 60 mastocitomas avaliados (destes, 1 era de grau 1 e 3 eram de grau 3), ou seja, em menos de $7 \%$ das amostras avaliadas, e concordância de $80 \%$ dos 
patologistas no diagnóstico de apenas 50\% dos mastocitomas. Possíveis causas para esta variação encontrada no estudo incluem a subjetividade em alguns critérios propostos no sistema de classificação de Patnaik, assim como a dificuldade em distinguir algumas características descritas neste sistema de classificação, ou mesmo a heterogeneidade histológica em diferentes áreas presentes numa mesma neoplasia.

Visando reduzir esta variância no nível de concordância entre patologistas no diagnóstico do mastocitoma cutâneo canino e promover uma melhora no valor prognóstico da graduação histológica, Kiupel et al. (2011) propuseram um novo sistema de classificação histológica desta neoplasia, dividindo-a em dois graus apenas: alto e baixo grau. De acordo com este sistema, o mastocitoma é considerado de alto grau quando apresenta uma destas características: pelo menos 7 figuras de mitose em 10 campos de maior aumento, pelo menos 3 células multinucleadas (3 ou mais núcleos) em 10 campos de maior aumento, pelo menos 3 núcleos bizarros (com alto grau de atipia e indentações, segmentação e formato irregular evidentes) em 10 campos de maior aumento ou presença de cariomegalia. Este estudo conclui que pelo sistema de classificação proposto por Patnaik, a principal variação no diagnóstico entre patologistas ocorre entre os mastocitomas de grau 1 e de grau 2, ressaltando também que não houve associação de aumento da mortalidade relacionada à doença ou diminuição da sobrevida comparando-se os graus 1 e 2. Por isso, Kiupel et al. (2011) sugerem que mastocitomas de grau 1 e 2 representam um grupo de neoplasias consideradas de baixo grau e portanto 0 sistema de classificação proposto por eles seria mais apropriado, eliminando a ambiguidade no diagnóstico das neoplasias moderadamente diferenciadas. Neste estudo, houve $99,3 \%$ de concordância no diagnóstico do mastocitoma entre os 28 patologistas recrutados.

Corroborando o estudo de Kiupel et al. (2011) e Takeuchi et al. (2012) conduziram um estudo retrospectivo avaliando 47 cães portadores de mastocitoma cutâneo. As neoplasias foram classificadas de acordo com os sistemas de graduação propostos por Kiupel e Patnaik. Utilizando-se o sistema de classificação de Patnaik, cães diagnosticados com mastocitomas de grau 3 apresentaram sobrevida e tempo livre de doença significativamente menores, quando comparados aqueles que apresentavam mastocitomas de graus 1 ou 2. No entanto, não houve diferença estatisticamente significante na sobrevida e tempo livre de doença entre os 
cães diagnosticados com mastocitomas de graus 1 e 2 . Já pelo sistema de classificação de Kiupel, cães portadores de neoplasias de alto grau tiveram sobrevida e tempo livre de doença significativamente menores quando comparados aos cães com neoplasias de baixo grau. Este estudo conclui que o sistema de graduação proposto por Kiupel apresenta importante valor prognóstico nos mastocitomas cutâneos caninos.

Apesar da importância do histopatológico para a correta graduação desta neoplasia, um estudo recente avaliou a aplicabilidade do exame citológico para a graduação de mastocitomas cutâneos em cães, baseando-se nas características descritas no sistema de graduação de Kiupel et al. (2011) (número de mitoses, células multinucleadas, núcleos bizarros e presença de cariomegalia). 50 mastocitomas foram avaliados por citologia previamente à sua remoção cirúrgica $e$ posteriormente o resultado citológico foi comparado ao histopatológico. A graduação das neoplasias em alto e baixo grau pela citologia corroborou o diagnóstico histopatológico em 47 casos, com uma acurácia de 94\%, sensibilidade de $84,6 \%$ e especificidade de $97,3 \%$, concluindo que o exame citológico pode fornecer dados importantes que auxiliarão na decisão pela melhor conduta terapêutica (SCARPA; SABATTINI; BETTINI, 2014) (No prelo) ${ }^{3}$.

Diferentemente dos mastocitomas cutâneos, os mastocitomas subcutâneos originam-se e restringem-se ao tecido adiposo do subcutâneo. Estes podem ser classificados de acordo com três diferentes padrões histológicos: circunscrito (bem delimitado, altamente celular e de crescimento expansivo, podendo eventualmente estender-se para a musculatura subjacente), combinado (nódulos solitários formados por células neoplásicas arranjadas em fileiras e agregados densos e células isoladas demarcadas por abundante tecido fibroso colágenos do tecido adjacente normal) e infiltrativo (células neoplásicas arranjadas de forma semelhante ao mastocitoma subcutâneo combinado, entretanto não há demarcação com o tecido adjacente normal) (THOMPSON et al., 2011a).

O exame de imunoistoquímica pode ser utilizado também para confirmar o diagnóstico do mastocitoma, assim como fornecer informação prognóstica sobre esta neoplasia. Este exame consiste na identificação de epítopos no tecido em

\footnotetext{
${ }^{3}$ SCARPA, F.; SABATTINI, S.; BETTINI, G. Cytological grading of canine cutaneous mast cell tumors. Veterinary and Comparative Oncology (Aceito para publicação em 2014).
} 
estudo através da reação antígeno-anticorpo, revelada por um marcador visual e examinada à microscopia óptica ou eletrônica. London et al. (1996); Reguera et al. (2000) e Preziosi et al. (2004) estabeleceram a expressão do receptor KIT em mastocitomas caninos, descrevendo três diferentes padrões de localização desta proteína, sendo eles membranoso, citoplasmático focal e citoplasmático difuso. Estes padrões correlacionam-se ao grau histológico e comportamento biológico da neoplasia. O receptor KIT é considerado um potencial marcador de mastócitos caninos, sendo útil portanto, para o diagnóstico de mastocitomas pouco diferenciados. A expressão de triptase também foi descrita como sendo um marcador imunoistoquímico com excelente sensibilidade e especificidade para mastócitos (WALLS et al., 1990; YANG et al., 2000). São descritos 3 diferentes padrões de marcação desta proteína: citoplasmática difusa, citoplasmática pontilhada e pouca a nenhuma marcação citoplasmática. No entanto, os diferentes padrões de marcação da triptase não correlacionam-se à sobrevida do paciente (KIUPEL et al., 2004). A imunomarcação com Ki-67 também é bastante utilizada, mas para fins prognósticos, visto que este é um marcador de proliferação celular (WEBSTER et al., 2007).

Meyer et al. (2012) identificaram a expressão do CD25 em mastocitomas cutâneos caninos, por imunoistoquímica. O CD25 é a subunidade- $\alpha$ do receptor de interleucina 2 (IL-2), sendo expresso principalmente por células $T$ regulatórias. Funcionalmente, o CD25 é essencial para a ligação da IL-2 ao seu receptor, estimulando desta forma a proliferação, diferenciação e sobrevivência de linfócitos $T$. $\mathrm{Na}$ oncologia humana, o CD25 é utilizado como ferramenta diagnóstica em pessoas portadoras de mastocitose sistêmica, sendo expresso por mastócitos neoplásicos na medula óssea, no trato gastrointestinal e na pele, mas não por mastócitos não neoplásicos nestes mesmos tecidos (KROKOWSKI et al., 2005; MALEK, 2008; LETOURNEAU et al., 2009). Segundo o estudo de Meyer et al. (2012), a expressão do CD25 em mastocitomas cutâneos caninos correlacionou-se ao grau da neoplasia, apresentando intensa marcação nos mastocitomas de grau 1 e pouca marcação nos mastocitomas de grau 3, pela graduação de Patnaik, enquanto que mastócitos cutâneos não neoplásicos não expressaram CD25. Os autores sugerem ainda que o CD25 possa estar envolvido na transformação maligna de mastocitos, uma vez que sua expressão é mais evidente nas neoplasias bem diferenciadas, ou seja, num 
estágio inicial da doença, e a medida que a neoplasia torna-se pouco diferenciada, ocorre uma perda gradual de sua expressão.

Uma vez estabelecido o diagnóstico de mastocitoma, deve-se realizar o estadiamento da neoplasia, a fim de determinar a extensão da doença e estabelecer a conduta terapêutica, assim como o prognóstico da neoplasia. De acordo com a Organização Mundial da Saúde (OMS) há 4 estágios clínicos para o mastocitoma canino, baseados no número e extensão das formações, comprometimento de linfonodo regional e presença de metástase a distância (Quadro 1) (LONDON; THAMM, 2013). No entanto, alguns estudos questionam a utilização deste sistema, principalmente em relação ao estágio III. De acordo com o estadiamento da OMS, múltiplos mastocitomas e neoplasias mais infiltrativas e volumosas são estadiadas igualmente como sendo de estágio III, embora diversos estudos sugerem que não há diferença no prognóstico de pacientes com apenas um ou com múltiplos nódulos que sejam de mesmo grau histológico. Por isso muito autores defendem que a categoria de 'múltiplos tumores' deva ser removida do estágio III e que cada nódulo deva ser estadiado individualmente em cães com múltiplos mastocitomas. Além disso, o termo 'infiltrativo' não seria apropriado se levarmos em consideração o sistema de graduação histológica proposto por Patnaik et al. (1984), onde nos mastocitomas de grau 2 e 3 há infiltração das células neoplásicas no subcutâneo e eles seriam sempre classificadas portanto em estágio III, mas sabe-se que muitos mastocitomas de grau 2 possuem um bom prognóstico. (MULLINS et al., 2006; MURPHY et al., 2006; WELLE et al., 2008). Da mesma forma, os mastocitomas subcutâneos são neoplasias que não apresentam envolvimento primário da derme e apresentam-se como massas subcutâneas bem delimitadas, de comportamento menos agressivo e de melhor prognóstico (NEWMAN et al., 2007; THOMPSON et al., 2011a, b), mas que pelo estadiamento da OMS seriam classificados como estágio III e teoricamente demandariam um tratamento mais agressivo do que 0 necessário (WELLE et al., 2008). 
Quadro 1 - Estadiamento clínico dos mastocitomas segundo a Organização Mundial da Saúde

\begin{tabular}{|l|l|}
\hline Estadiamento & Características \\
\hline Estágio 0 & $\begin{array}{l}\text { Tumor único, incompletamente excisado, confinado a derme, sem } \\
\text { envolvimento de linfonodo regional } \\
\text { Sem sinais clínicos } \\
\text { Com sinais clínicos }\end{array}$ \\
\hline Estágio I & $\begin{array}{l}\text { Tumor único confinado a derme, sem envolvimento de linfonodo } \\
\text { regional } \\
\text { Sem sinais clínicos } \\
\text { Com sinais clínicos }\end{array}$ \\
\hline Estágio II & $\begin{array}{l}\text { Tumor único confinado a derme, com envolvimento de linfonodo } \\
\text { regional } \\
\text { Sem sinais clínicos } \\
\text { Estágio III }\end{array}$ \\
$\begin{array}{l}\text { Com sinais clínicos } \\
\text { Tumores múltiplos ou grandes, com ou sem envolvimento de } \\
\text { linfonodo regional } \\
\text { Sem sinais clínicos } \\
\text { Com sinais clínicos }\end{array}$ \\
\hline Estágio IV & $\begin{array}{l}\text { Tumor com presença de metástase a distância, ou recidiva com } \\
\text { metástase (incluindo invasão medular ou presença de mastócitos } \\
\text { no sangue periférico) }\end{array}$ \\
\hline
\end{tabular}

Fonte: (LONDON; THAMM, 2013)

De forma geral, sugere-se a realização de hemograma, perfil bioquímico completo, ultrassonografia abdominal, radiografia torácica e citologia do linfonodo regional para o estadiamento do mastocitoma cutâneo. Raramente mastócitos estarão presentes no sangue periférico de cães portadores desta neoplasia. Este quadro é mais comumente observado quando a doença evolui para mastocitose, ou no mastocitoma visceral em gatos (BLACKWOOD et al.., 2012). Citologia aspirativa de baço e fígado em cães portadores de mastocitoma cutâneo, com aspecto ultrassonográfico normal, não demonstrou ser uma ferramenta diagnóstica útil no estadiamento desta neoplasia (FINORA et al., 2006). Aspirado da medula óssea deve ser realizado, principalmente tratando-se dos mastocitomas de alto grau. A 
presença de mastócitos neoplásicos na medula óssea é rara e muitas vezes o animal pode não apresentar nenhuma anormalidade hematológica no sangue periférico (MARCONATO et al., 2008). Mas Endicott et al. (2007) demonstraram que a presença de eosinofilia no sangue periférico está associada com o envolvimento da medula óssea e acredita-se que a própria neoplasia é capaz de estimular a produção destas células. Segundo um estudo de Aubry et al. (2012), realizou-se a punção de medula óssea em 14 cães portadores de mastocitoma de alto grau. Destes, 3 (21,4\%) apresentavam comprometimento de medula óssea, sendo que em 2 cães a presença de células neoplásicas foi observada tanto na punção da região proximal do úmero, como na asa do íleo, enquanto que no terceiro cão o envolvimento da medula óssea foi observado apenas na punção da asa do íleo. Destes 3 cães, 1 apresentava eosinofilia. Este estudo sugere a distribuição das células neoplásicas pode não ser uniforme quando há comprometimento de medula óssea e que por isso seria mais prudente realizar a punção de medula óssea em diferentes locais, visando aumentar a acurácia deste exame e evitar diagnósticos falso-negativos em cães com mastocitoma de alto grau principalmente.

A citologia de linfonodo regional deve sempre ser realizada, mesmo que o linfonodo não esteja aumentado, já que a principal via de metástase desta neoplasia é a via linfática. A avaliação citológica é útil para pesquisa de metástase e planejamento terapêutico, além de ser um importante fator prognóstico (MURPHY et al., 2006). Apesar de ser um exame rápido, simples e de baixo custo, dependendo da região aspirada e do grau de comprometimento do linfonodo, podemos ter um resultado falso-negativo para a presença de metástase (KRICK et al., 2009). Vale ressaltar que cães hígidos podem apresentar alguns mastócitos em linfonodos e sua presença deve ser considerada normal. Bookbinder, Butt e Harvey (1992) avaliaram por citologia 36 linfonodos poplíteos de cães hígidos, quanto à presença de mastócitos e foram observados de 1 a 16 mastócitos (média de 6,4 mastócitos) por lâmina. Segundo Gosset et al. (1987), mastócitos podem representar $0.02-0.03 \%$ da população celular num linfonodo normal. Além disso, a presença de mastócitos pode estar aumentada num linfonodo reativo ou hiperplásico, associados a reações de hipersensibilidade (MILLS, 1989). Por isso, a simples presença de mastócitos em linfonodos não pode ser caracterizada como metástase. Segundo as diretrizes da OMS, a avaliação de metástase em linfonodo considera apenas a presença ou 
ausência de mastócitos, o que pode levar consequentemente a um diagnóstico incorreto de metástase (RASKIN, 2001; SEGUIN et al., 2001).

Diversos autores relatam que a falta de um critério citológico padronizado que possa ser utilizado para diferenciar a presença de mastócitos reativos e mastócitos neoplásicos em linfonodos, principalmente quando poucos mastócitos são identificados, tornando um desafio para o patologista a avaliação citológica de linfonodos regionais de mastocitomas cutâneos caninos. Alguns dos critérios descritos são: presença de agrupamentos ou fileiras de mastócitos, maior número de mastócitos em dois ou mais campos consecutivos de maior aumento ou mastócitos representando mais de $3 \%$ da população celular do linfonodo, na ausência de inflamação ou hiperplasia linfoide e a presença de mastócitos pouco diferenciados no linfonodo (DUNCAN, 1999; LANGENBACH et al., 2001; GIEGER et al., 2003; CAHALANE et al., 2004; THAMM; TUREK; VAIL, 2006; DOBSON; SCASE, 2007; WEBSTER et al., 2008 ). Krick et al. (2009) descreveram um sistema de avaliação citológica de linfonodos regionais de cães portadores de mastocitoma, proposto pelo Serviço de Patologia Clínica do Hospital Veterinário Matthew J. Ryan, da Universidade da Pensilvânia (Quadro 2), baseado no número e morfologia de mastócitos individuais e em agrupamentos. 
Quadro 2 - Critérios citológicos utilizados proposto pelo Serviço de Patologia Clínica do Hospital Veterinário Matthew J. Ryan, da Universidade da Pensilvânia para a determinação de metástase de mastocitoma em linfonodos regionais

\begin{tabular}{|l|l|}
\hline Interpretação & Descrição \\
\hline Normal & Mastócitos não visualizados \\
\hline Hiperplasia & $\begin{array}{l}\text { Mais de 50\% de linfócitos pequenos com uma população mista } \\
\text { de prolinfócitos, linfoblastos, plasmócitos, e/ou poucos a } \\
\text { moderados números de macrófagos, neutrófilos e eosinófilos, } \\
\text { e/ou raros mastócitos isolados }\end{array}$ \\
\hline $\begin{array}{l}\text { Possível } \\
\text { metástase }\end{array}$ & $\begin{array}{l}\text { Em pelo menos uma lâmina, duas a três incidências de } \\
\text { mastócitos em agregados de duas a três células }\end{array}$ \\
\hline Provável & $\begin{array}{l}\text { Em pelo menos uma lâmina, mais de três focos de mastócitos } \\
\text { em agregados de duas a três células e/ou dois a cinco } \\
\text { agregados de mais de três mastócitos }\end{array}$ \\
\hline $\begin{array}{l}\text { Metástase } \\
\text { evidente }\end{array}$ & $\begin{array}{l}\text { Em pelo menos uma lâmina, destruição do tecido linfoide por } \\
\text { mastócitos, e/ou presença de agregados de mastócitos pouco } \\
\text { diferenciados, com pleomorfismo, anisocitose, anisocariose } \\
\text { e/ou redução ou variação na granulação intracitoplasmática dos } \\
\text { mastócitos presentes, e/ou mais de cinco agregados compostos } \\
\text { por mais de três mastócitos }\end{array}$ \\
\hline
\end{tabular}

Fonte: (KRICK et al., 2009)

Neste estudo utilizou-se um sistema de estadiamento modificado, diferentemente do proposto pela OMS. Cães com mastocitomas múltiplos foram incluídos, sendo que aqueles que não apresentavam sinais de metástase à distância, nem em linfonodos regionais, eram categorizados como estágio I, enquanto que aqueles com evidência de metástase em linfonodo foram categorizados como estágio II. Esta avaliação foi realizada através de exames complementares, como hemograma, perfil bioquímico, urinálise, ultrassonografia abdominal, punção de medula óssea e citologia de linfonodo regional. Foram avaliados no total 152 cães. $63,8 \%$ dos cães apresentavam doença em estágio I e 36,2\% em estágio II. Cães em estágio II tiveram sobrevida significativamente menor ( 0,8 anos) em comparação aos cães em estágio I (6,2 anos) $(P<0,0001)$. Cães com mastocitomas de grau 3 eram mais 
propensos a apresentar a doença em estágio II em relação a cães com mastocitomas de graus 1 ou 2 , segundo a graduação de Patnaik $(P=0,004)$. $O$ estudo sugere que a avaliação citológica de linfonodos regionais de cães portadores de mastocitomas, baseada nos critérios deste estudo, é uma ferramenta útil na avaliação clínica destes pacientes, pois os resultados correlacionam-se ao grau histológico da neoplasia e ao prognóstico.

Outro critério de avaliação de metástase em linfonodo regional de mastocitoma descrito na literatura, é a utilização da morfometria nuclear, associada à quantificação de mastócitos no linfonodo, a fim de detectar doença micrometastática. Foi realizado um estudo avaliando linfonodos regionais de cães saudáveis, cães com doença inflamatória e cães com mastocitoma, por meio de análise citológica. Os cães portadores de mastocitoma $(n=27)$ foram subdivididos em 3 grupos: animais sem evidências de metástase em linfonodo, animais com mastócitos ocasionais em linfonodo e animais com metástase evidente em linfonodo. Os mastócitos nos linfonodos foram avaliados morfometricamente, considerando-se área nuclear média (MNA) e perímetro nuclear médio (MNP), para avaliação do tamanho nuclear; maior e menor diâmetro do núcleo e fator de forma nuclear médio, para caracterização do formato nuclear e coeficiente de variação da área nuclear para avaliar anisocariose. O estudo mostrou que a porcentagem média de mastócitos em linfonodos era bem maior no grupo de cães com mastocitoma, em comparação ao grupo de cães saudáveis e com doença inflamatória. Demonstrou também que a morfometria é um método eficaz na detecção de metástase precoce em linfonodo, uma vez que a MNA e MNP eram significativamente maiores nos pacientes do subgrupo que tinham metástase evidente em linfonodo em comparação aos animais do grupo com doença inflamatória $(P<0,05)$. Além disso, a avaliação da MNA e MNP nos animais do subgrupo com mastócitos ocasionais em linfonodos permitiu comprovar a presença de doença micrometastática nestes linfonodos, mostrando que a morfometria nuclear pode contribuir para uma melhora na sensibilidade do diagnóstico de metástase em linfonodos regionais de cães portadores de mastocitoma cutâneo (MARCONATO et al., 2008). Strefezzi, Xavier e Catão-Dias (2003) também reportaram o uso da morfometria como ferramenta auxiliar no diagnóstico do mastocitoma cutâneo. Em seu estudo, os parâmetros morfológicos nucleares foram avaliados e correlacionados ao grau histológico da neoplasia, mostrando que os valores de área nuclear, diâmetro médio e perímetro nucleares aumentavam de 
acordo com o aumento do grau histológico do mastocitoma. Estes autores concluíram ainda que a análise morfométrica nuclear pode auxiliar na graduação do mastocitoma através do exame citológico. Maiolino et al. (2005) observaram igualmente relação entre morfometria nuclear e graduação histológica dos mastocitomas cutâneos caninos.

Independentemente do critério utilizado na avaliação citológica do linfonodo, a confirmação de metástase no mesmo se dá através do exame histopatológico, onde também pode-se observar uma variação significante entre patologistas na interpretação de metástase, principalmente na presença de mastócitos isolados ou de agrupamentos de mastócitos restritos à região sinusoidal do linfonodo (THRALL, 1987; WORLEY, 2012). Diante disto, recentemente Weishaar et al. (2014) (no prelo) ${ }^{4}$ propuseram um sistema de classificação histopatológica para a determinação de metástase linfonodal (Quadro 3), considerando: número e distribuição dos mastócitos no linfonodo, assim como alteração ou perda na arquitetura normal do linfonodo, ou aumento de celularidade na região sinusoidal. Este estudo também investigou se os diferentes padrões de metástase em linfonodo correlacionam-se ao prognóstico. Foram avaliados 48 mastocitomas e seus respectivos linfonodos regionais. Os casos que apresentaram maior número de mastócitos, assim como maior comprometimento do linfonodo, tiveram menor tempo livre de doença e menor sobrevida quando comparados aqueles que exibiam menor quantidade de mastócitos em linfonodos e menor desarranjo da arquitetura linfonodal, evidenciando que este novo sistema de classificação proposto correlacionou-se ao prognóstico. Logo, este sistema poderia ser utilizado por patologistas, a fim de padronizar o diagnóstico histopatológico de linfonodos regionais de cães com mastocitoma cutâneo.

\footnotetext{
${ }^{4}$ WEISHAAR, K. M.; THAMM, D. H.; WORLEY, D. R.; KAMSTOCK, D. Correlation of nodal mast cells with clinical outcome in dogs with mast cell tumour and a proposed classification system for the evaluation of node metastasis. Journal of Comparative Pathology. (Aceito para publicação em 2014).
} 
Quadro 3 - Novo sistema de classificação para avaliação microscópica de metástase em linfonodo em cães com mastocitoma

\begin{tabular}{|c|c|c|}
\hline Classificação & Critério histopatológico & Interpretação proposta \\
\hline HNO & $\begin{array}{l}\text { Nenhum a raros (0-3) } \\
\text { mastócitos dispersos, } \\
\text { individualizados (isolados) } \\
\text { na região dos seios } \\
\text { (subcapsular, paracortical } \\
\text { ou medular) e/ou } \\
\text { parênquima por campo de } \\
400 x \text { (0-3 mastócitos por } \\
\text { campo de } 400 x \text { ), ou não se } \\
\text { aplica a nenhum dos } \\
\text { critérios da classificação } \\
\text { proposta }\end{array}$ & Não-metastático \\
\hline HN1 & $\begin{array}{l}\text { Mais de três mastócitos } \\
\text { isolados na região dos } \\
\text { seios } \\
\text { paracortical ou medular) } \\
\text { e/ou parênquima em pelo } \\
\text { menos } 4 \text { campos de 400x }\end{array}$ & Pré-metastático \\
\hline $\mathrm{HN} 2$ & $\begin{array}{l}\text { Agregados } \text { (clusters) } \text { de } \\
\text { mastócitos (3 ou mais } \\
\text { células agrupadas) na } \\
\text { região dos seios } \\
\text { (subcapsular, paracortical } \\
\text { ou medular) e/ou } \\
\text { parênquima ou "lencóis" de } \\
\text { mastócitos em região } \\
\text { sinusoidal }\end{array}$ & Metástase inicial \\
\hline HN3 & $\begin{array}{l}\text { Perda da arquitetura } \\
\text { normal do linfonodo por } \\
\text { discretos focos, nódulos, } \\
\text { "lençóis" ou formações } \\
\text { evidentes compostas por } \\
\text { mastócitos }\end{array}$ & Metástase evidente \\
\hline
\end{tabular}

Fonte: (WHEISHAAR et al., 2014)

$\mathrm{Na}$ avaliação dos linfonodos, pode-se utilizar também como ferramenta diagnóstica, a coloração por histoquímica com o azul de toluidina, que por ser um corante catiônico (básico) promove o fenômeno de metacromasia dos grânulos citoplasmáticos dos mastócitos, os quais adquirem uma coloração violácea, diferindo do restante do tecido, que adquire uma coloração azulada. Desta forma, podemos evidenciar a presença de mastócitos em linfonodos. Por isso, esta técnica de histoquímica é altamente recomendada na avaliação histopatológica de linfonodos regionais de mastocitomas cutâneos (CARSON, 1997; WEISHAAR et al., 2014) (no 
prelo) $)^{5}$. Outra técnica de histoquímica pouco utilizada, porém eficaz na detecção de mastócitos é a coloração pelo aldeído-fucsina de Gomori, que cora os grânulos dos mastócitos em vermelho (GOMORI, 1950; DAGLI et al., 1992). Esta técnica permite diversos procedimentos de coloração e tem afinidade principalmente para fibras elásticas, mas também grânulos da células beta do pâncreas e mastócitos (MCMANUS; MOWRY, 1965; MASSIRONI et al., 2005).

A ultrassonografia abdominal é realizada principalmente para pesquisa de metástase em fígado e baço, mas é um exame útil também na avaliação de linfonodos intra-abdominais, como os ilíacos e sublombares por exemplo, quando estes representam linfonodos sentinela de mastocitomas. Estudos mostram que linfonodos metastáticos apresentam alteração em seu formato (tendem a ser mais arredondados) e distorção da arquitetura interna, normalmente são hipoecogênicos, heterogêneos, possuem contornos irregulares e vascularização periférica (NYMAN et al., 2004; SWARTE et al., 2011).

Um estudo reportou o estadiamento de 220 cães com mastocitoma cutâneo por meio da avaliação do linfonodo regional por palpação ou citologia, ultrassonografia abdominal e radiografia torácica. 30,9\% dos animais apresentavam metástase em linfonodo regional e apenas 6,8\% metástase à distância, sendo que nenhum cão tinha evidência de metástase pulmonar. $O$ estudo sugere que a radiografia torácica é de pouca valia no estadiamento do mastocitoma cutâneo canino e que a ocorrência de metástase à distância ocorre a partir da metástase no linfonodo sentinela, ressaltando a importância da avaliação do mesmo (WARLAND et al., 2012) (no prelo $)^{6}$.

Thamm e Vail (2011) propuseram um esquema de diagnóstico para mastocitomas cutâneos caninos, baseando-se na presença ou ausência de fatores prognósticos (Figura 1).

\footnotetext{
5,6 WARLAND, J.; AMORES-FUSTER, I.; NEWBURY, W.; BREARLEY, M.; DOBSON, J. The utility of staging in canine mast cell tumours $(\dagger)$.Veterinary and Comparative Oncology. (Aceito para publicação em 2012).
} 
Figura 1 - Esquema proposto para o diagnóstico do mastocitoma cutâneo canino

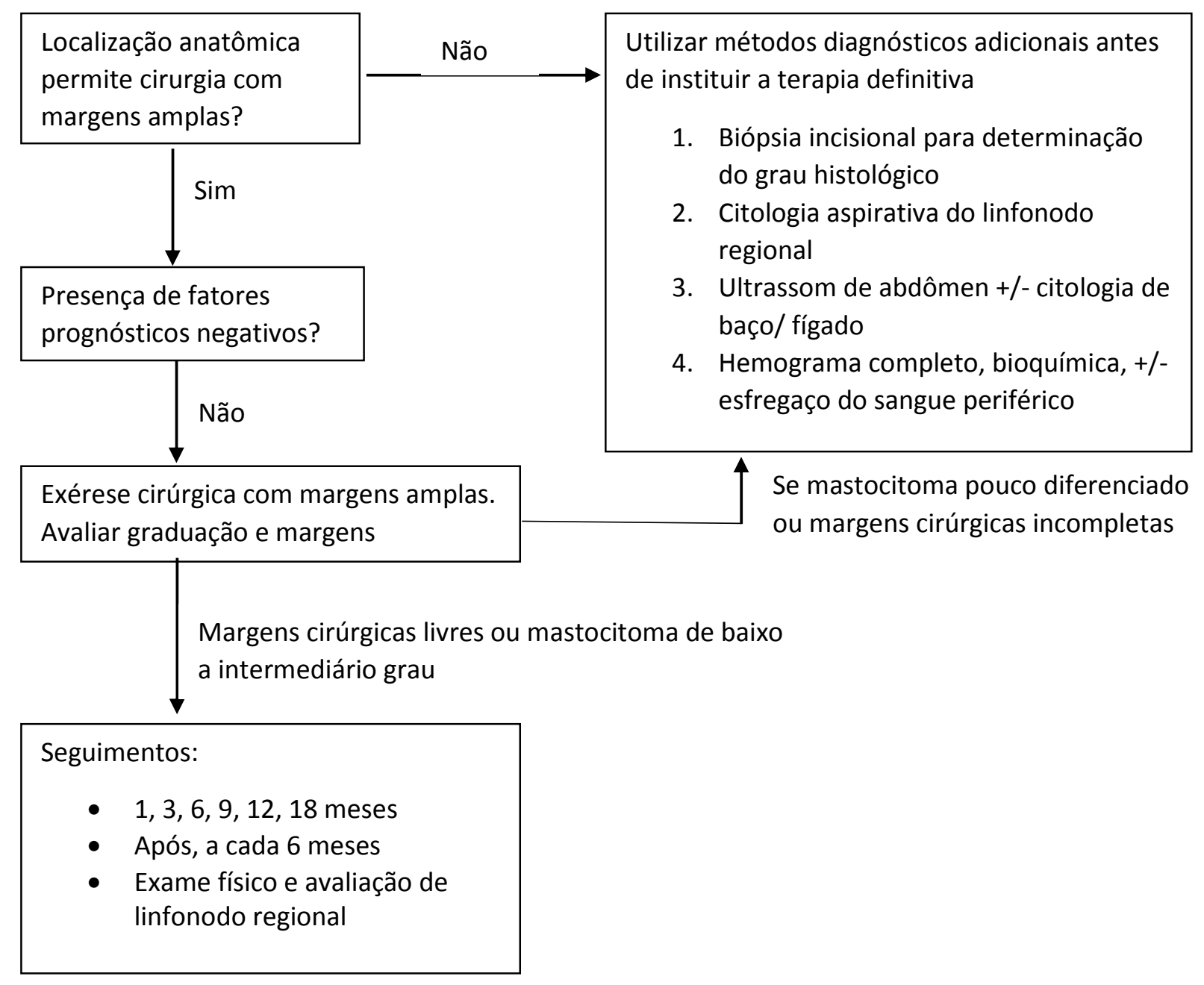

Fonte: (THAMM; VAIL, 2007)

\subsubsection{Fatores prognósticos}

Não há um fator prognóstico isolado que possa caracterizar o comportamento biológico ou a resposta ao tratamento em cães com mastocitoma cutâneo. Diversos fatores são descritos na literatura, mas aqueles que apresentam maior valor prognóstico são: grau histológico, estadiamento clínico, localização da neoplasia, índice de proliferação celular, velocidade de crescimento, ploidia de DNA, densidade microvascular, recidiva local, presença de sinais sistêmicos, raça, volume tumoral e mutação do gene c-kit. 
O grau histológico da neoplasia parece ser o fator prognóstico de maior impacto na sobrevida de cães com mastocitoma cutâneo. O estudo de Patnaik, Ehler e Macewen (1984) que graduou os mastocitomas em 3 graus, correlacionou esta graduação à sobrevida em 83 cães tratados unicamente por cirurgia. A porcentagem de cães com mastocitomas cutâneos de graus 1, 2 e 3 que apresentaram sobrevida acima de 1500 dias, foi de $93 \%, 44 \%$ e $6 \%$, respectivamente. O índice de metástase para mastocitomas de grau 1 é menor que $10 \%$ (WELLE et al., 2008), de 5-22\% para os mastocitomas de grau 2 (SEGUIN et al., 2001; WEISSE; SHOFER; SORENMO, 2002) e de 55-96\% para os mastocitomas de grau 3 (BOSTOCK, 1973; HUME et al., 2011). Entretanto, mastocitomas de grau 2, que representam mais de $40 \%$ dos diagnósticos de mastocitoma cutâneo canino, possuem comportamento imprevisível, podendo comportar-se de forma benigna, ou recidivar ou metastatizar (SEGUIN et al., 2001; WEISSE; SHOFER; SORENMO, 2002). Já no estudo de Kiupel et al. (2011), que graduou os mastocitomas apenas em 2 graus, esta variação de comportamento em mastocitomas moderadamente diferenciados não foi observada. $O$ estudo relata que dos 95 cães com mastocitomas tratados apenas por cirurgia, 10 eram de alto grau e apresentaram menor sobrevida (menos de 4 meses) e maior chance de desenvolverem metástase ou um novo mastocitoma. Já os 85 cães portadores de mastocitoma de baixo grau tiveram mais de 2 anos de sobrevida.

Estudos apontam que os mastocitomas subcutâneos possuem um prognóstico mais favorável em comparação aos mastocitomas cutâneos, estando relacionados à maior sobrevida e menor taxa de recidivas e metástases (NEWMAN et al., 2007; THOMPSON et al., 2011a, b).

O estadiamento clínico tem um importante valor prognóstico em diversas neoplasias em humanos e em animais. De acordo com o estadiamento da OMS para o mastocitoma canino, animais em estágio 0 ou I possuem um melhor prognóstico em relação aqueles em estágios II, III ou IV e a presença de metástase no momento do diagnóstico reduz a sobrevida do paciente de forma significante. No entanto, estudos recentes mostram que animais em estágio II podem ser tratados com sucesso, apresentando tempo livre de doença comparável aos animais que apresentavam-se em estágio 0 . Além disso, animais que apresentavam múltiplos mastocitomas e foram tratados cirurgicamente, tiveram menor índice de metástase à distância e melhor prognóstico e sobrevida. Estes estudos sugerem que com 
tratamento apropriado, o estadiamento clínico tem menor valor prognóstico quando comparado a outros fatores prognósticos (WELLE et al., 2008).

O estudo de Thamm et al. (1999) refere que cães com mastocitomas múltiplos não apresentaram menor sobrevida em relação a cães com mastocitomas únicos, demonstrando que mastocitomas múltiplos representam neoplasias independentes que surgiram após a neoplasia primária, e não uma metástase cutânea do mastocitoma primário. Por isso, o estadiamento do mastocitoma proposto pela OMS, que classifica mastocitomas múltiplos como um estágio avançado da doença, pode não ser um sistema confiável em predizer o prognóstico desta apresentação clínica da doença.

Já a presença de metástase em linfonodos em cães com mastocitomas é considerado um fator prognóstico negativo e tem impacto direto na evolução clínica da doença e na conduta terapêutica (THAMM; MAULDIN; VAIL, 1999; GIEGER et al., 2003; MURPHY et al., 2006; THAMM et al., 2006; MARCONATTO et al., 2008; KRICK et al., 2009; HUME et al., 2011; BLACKWOOD et al., 2012; WORLEY, 2012; WEISHAAR et al., 2014 (no prelo) ${ }^{7}$ ). Krick et al. (2009) encontrou associação entre grau histológico do neoplasia e presença de metástase em linfonodo, mostrando que mastocitomas de grau 3 apresentaram comportamento biológico mais agressivo e maior índice de metástase para linfonodo regional. Além disso, os mastócitos metastáticos nos linfonodos, de mastocitomas de grau 3 , exibiam maior grau de anaplasia em relação aqueles observados nas neoplasias de graus 1 ou 2 . Resultado semelhante foi observado no estudo de Weishaar et al. (2014) (no prelo) ${ }^{8}$ onde animais classificados no grupo HNO exibiram maior tempo livre de doença e sobrevida em relação aos animais do grupo HN2 (vide Quadro 3). Hume et al. (2011) mostrou que de 43 cães diagnosticados com mastocitoma de grau 3, 21 apresentavam metástase em linfonodo e estes animais tiveram 194 dias de sobrevida, comparados a 503 dias naqueles que não apresentavam metástase. Os animais que receberam tratamento do linfonodo (radioterapia ou remoção cirúrgica) atingiram 240 dias de sobrevida, comparados a 42 dias naqueles que não receberam nenhum tipo de tratamento. Entretanto, o estudo de Chaffin e Thrall

\footnotetext{
7,8 WEISHAAR, K. M.; THAMM, D. H.; WORLEY, D. R.; KAMSTOCK, D. Correlation of nodal mast cells with clinical outcome in dogs with mast cell tumour and a proposed classification system for the evaluation of node metastasis. Journal of Comparative Pathology. (Aceito para publicação em 2014).
} 
(2002) evidenciou que cães com mastocitoma moderadamente diferenciado e metástase em linfonodo tratados por radioterapia tiveram sobrevida elevada, atingindo 1240 dias. Ademais, o estudo de Takeuchi et al. (2012) apontou que a presença de metástase em linfonodo foi considerada um marcador prognóstico independente na determinação da sobrevida. No entanto, dependendo do parâmetro utilizado para definir metástase em linfonodo, resultados diferentes podem ser encontrados (KRICK et al., 2009). Se consideramos que a metástase em linfonodo é definida quando há maior número de mastócitos em dois ou mais campos consecutivos de maior aumento, o estudo de Cahalane et al. (2004) mostrou que tanto o estadiamento como o tamanho do linfonodo não tiveram impacto na sobrevida em análise multivariada. Já no estudo de Gieger et al. (2003), foram avaliados cães portadores de mastocitoma na região do nariz, e o linfonodo foi considerado metastático na presença de elevado número de mastócitos ou na presença de mastócitos pouco diferenciados. Este estudo concluiu que a presença de metástase em linfonodo foi um importante fator prognóstico, com impacto na sobrevida.

Mastocitomas localizados no leito ungueal, cavidade oral, nariz, região inguinal e perineal, prepúcio e áreas mucocutâneas estão relacionados à um pior prognóstico quando comparados a outras regiões do corpo (O'KEEFE, 1990; GIEGER et al., 2003; GOVIER, 2003; MULLINS et al., 2006; LONDON; THAMM, 2013). No entanto, alguns autores discordam (CAHALANE et al., 2004; SFILIGOI et al., 2005). Turrel et al. (1988) relatam também que a sobrevida em cães com mastocitomas incompletamente excisados e tratados por radioterapia, foi maior nos animais que apresentavam tumores nas extremidades do que naqueles que apresentavam no tronco. Já o mastocitoma visceral, apesar de incomum, possui prognóstico ruim, uma vez que diferentemente do mastocitoma cutâneo, possui comportamento biológico mais agressivo (TAKAHASHI et al., 2000).

Neoplasias volumosas, apresentaram pior prognóstico após tratamento cirúrgico associado ou não à radioterapia. O estudo de Hahn, King e Carreras (2004) relata que o tamanho do tumor previamente à cirurgia influencia diretamente o tempo de remissão da doença. Neste estudo, cães com mastocitomas maiores que $3 \mathrm{~cm}$ em seu maior diâmetro sobreviveram 24 meses, em relação a 31 meses de sobrevida naqueles onde 0 mastocitoma tinha menos que $3 \mathrm{~cm}$ no seu maior diâmetro. 
Ulceração, eritema e prurido também são fatores prognósticos negativos (THAMM; MAULDIN; VAIL, 1999; LONDON; THAMM, 2013).

Marcadores de proliferação celular podem predizer o prognóstico e resposta à terapia e são considerados menos subjetivos em relação a outros indicadores prognósticos. Estudos apontam que os mais utilizados são: índice mitótico (IM), proteína Ki-67, antígeno nuclear de proliferação celular (PCNA) e proteínas associadas a região organizadora nucleolar com afinidade pela prata (AgNOR) (SIMÕES et al., 1994; SCASE et al., 2006; WEBSTER et al., 2007; MAGLENNON et al., 2008; STREFEZZI et al., 2010; VASCELLARI et al., 2013).

O IM é a contagem de figuras de mitose em 10 campos de maior aumento, identificado por exame histopatológico, e que tem sido amplamente utilizado para estimar o comportamento biológico do mastocitoma cutâneo canino (MAIOLINO et al., 2005; PREZIOSI et al., 2007; ELSTON et al., 2009; VASCELLARI et al., 2013). Apesar da técnica ser simples, pode apresentar alguns problemas de reprodutibilidade por não ser possível realizar a seleção dos mesmos campos, além de representar apenas uma fase do ciclo celular, a fase de mitose (fase M) (QUINN; WRIGHT, 1990). Num estudo conduzido por Romanski et al. (2007), a sobrevida média de cães portadores de mastocitoma com IM de 5 ou menos, foi de 70 meses, comparado a apenas 2 meses naqueles onde $O$ IM foi maior que 5, independentemente da graduação histológica da neoplasia, corroborando os resultados encontrados no estudo de Vascellari et al. (2013), onde a sobrevida foi menor e a mortalidade maior quando o IM era acima de 5 . Um estudo anterior já havia mostrado que a sobrevida média de cães com mastocitoma de IM de 10 ou mais, foi de apenas 11 semanas (BOSTOCK et al., 1989). Elston et al. (2009) sugerem a estratificação do $\mathrm{IM}$ em 3 grupos ( $\mathrm{IM}=0$; $\mathrm{IM}$ 1-7 e $\mathrm{IM}>7$ ), correlacionando-os também à sobrevida. Kiupel et al. (2011), em seu novo sistema de graduação dos mastocitomas cutâneos caninos, adotaram como ponto de corte do IM o valor de 7 ou mais figuras de mitose em 10 campos de maior aumento nos mastocitomas de alto grau, conforme proposto por Elston et al. (2009).

Já o Ki-67 é uma proteína nuclear expressa em todas as fases do ciclo celular, mas não é expressa nas células que não estão em divisão, ou seja, determina o número de células que estão ativamente no ciclo celular, de início de $G 1$ a fase $M$. $A$ localização e expressão desta proteína são reguladas durante o ciclo celular, além dela ser necessária para a progressão na célula no ciclo, uma vez que sua inibição 
leva a parada do ciclo celular. Por possuir meia-vida curta e degradar-se cerca de uma hora após a mitose, mesmo marcações tênues do Ki-67 podem ser consideradas positivas. $\mathrm{O}$ anticorpo monoclonal MIB-1 é utilizado para detectar a expressão da proteína Ki-67 e tem sido utilizado na maior parte dos estudos em cães e humanos (QUINN; WRIGHT, 1990; LAPRIE et al., 1998; ROELS et al., 1999; SCASE et al., 2006; WEBSTER et al., 2007). Em diversas neoplasias caninas, a frequência da expressão do Ki-67 em células neoplásicas está significantemente associada ao prognóstico, incluindo os mastocitomas (PENA et al., 1998; PHILLIPS et al., 2000; LAPRIE et al., 2001; LABELLE et al., 2004; VASCELLARI et al., 2012). Diversas pesquisas apontam que o Ki-67 correlaciona-se ao grau histológico do mastocitoma, apresentando maior número de células positivas nas neoplasias pouco diferenciadas. A alta expressão de Ki-67 também está associada ao aumento da mortalidade, maior índice de recidiva local e metástase. Além disso, o Ki-67 mostrou ser um indicador prognóstico independente da graduação histológica, principalmente tratando-se dos mastocitomas de grau 2 (pela graduação de Patnaik), onde a imunomarcação por esta proteína fornece maior precisão na determinação do comportamento biológico desta neoplasia (ABADIE et al., 1999; WEBSTER et al., 2008). Cães portadores de mastocitoma de grau 2 que exibiam quantificação de Ki67 menor ou igual a 1,8\% dos mastócitos marcados, apresentaram maior sobrevida em relação aqueles onde o índice de marcação do ki-67 foi maior que 1,8\% (SCASE et al., 2006; MAGLENNON et al., 2008). Diferentes métodos de avaliação do Ki-67 são descritos na literatura. Abadie et al. (1990) e Sakai et al. (2002) determinam a porcentagem de núcleos positivos em um mínimo de 1000 núcleos ao acaso, em 10 campos randomizados, em objetiva de 40x. Núcleos positivos e negativos são quantificados manualmente com 0 auxílio de determinados softwares de processamento de imagens. Strefezzi et al. (2010) utilizou um método semelhante ao de Abadie et al. (1990) e Sakai et al. (2002), no entanto realizou a contagem de núcleos positivos em um mínimo de 1000 núcleos em campos de alta frequência de marcação (hot spot), em objetiva de 40x. Já Scase et al. (2006) e Maglennon et al. (2008) descrevem o método de contagem celular por um programa de computador que capta a imagem digitalmente, em objetiva de 20x. O campo escolhido corresponde à uma área a um terço de distância da margem profunda e da margem lateral da neoplasia e as células positivas e negativas são contadas neste campo. Outro método descrito por Webster et al. (2007) é a avaliação do Ki-67 por meio da 
identificação ao microscópio das áreas com maior marcação (hot spot) em objetiva de 10 aumentos e a partir da identificação destas áreas, as células positivas são contadas com o auxílio de um retículo de $1 \mathrm{~cm}^{2}$ em objetiva de 40 aumentos, em 5 campos. Independentemente do método utilizado para a contagem do Ki-67, as pesquisas apontam que um alto índice de Ki-67 está sempre associado à menor sobrevida em cães portadores de mastocitoma. Abadie et al. (1990) concluiu que cães com mastocitoma de grau 2 (pela graduação de Patnaik) que apresentavam acima de 93 núcleos positivos, tiveram menor sobrevida em relação àqueles que tinham menos de 93 núcleos positivos/ 1000 núcleos. Strefezzi et al. (2010) mostrou que cães com menos de $7 \%$ de células positivas para o Ki-67 tiveram maior sobrevida em relação àqueles que exibiram Ki-67 igual ou superior a 7\%, apesar de não ter encontrado diferenças significantes na sobrevida de cães com mastocitomas de grau 2 com base nos scores de ki-67, provavelmente devido ao baixo número de cães analisados neste estudo. Os dois estudos conduzidos por Webster e colegas concluíram que animais com Ki-67 acima de 23 apresentaram maior índice de recidiva, metástase e mortalidade associada à doença (WEBSTER et al., 2007; WEBSTER et al., 2008).

PCNA é uma proteína que interage com as enzimas DNA polimerases, atuando com um fator auxiliar na replicação e no reparo do DNA. Apesar desta proteína ter uma meia-vida longa e estar envolvida em diversas funções nucleares, sua maior expressão é identificada principalmente na fase de síntese (fase $S$ ) do ciclo celular, mas pode ser detectada também desde a fase G1 até a transição G2-M. Alguns estudos mostram uma associação da expressão desta proteína com o aumento da mortalidade em cães com mastocitoma (SIMÕES et al., 1994; WEBSTER et al., 2007). Simões et al. (1994) concluíram ainda que a alta expressão de PCNA correlacionou-se à um maior índice de metástase e recidiva local. No entanto, diversos estudos demonstraram que este marcador de proliferação celular não possui valor prognóstico estatisticamente significante quando utilizado isoladamente (ABADIE et al., 1990; SIMÕES; SCHONING, 1994; SCASE et al., 2006; WELLE et al., 2008).

AgNORs são áreas nucleolares que estão envolvidas na transcrição do RNA ribossomal. São amplamente utilizadas como marcadores da cinética tumoral e da atividade metabólica tumoral. AgNORs ligam-se a moléculas de prata, através de colorações histoquímicas, permitindo a visualização do nucléolo, onde serão 
avaliados o seu tamanho e o número de pontos corados pela prata. A quantidade de AgNORs por núcleo é proporcional à taxa de crescimento tumoral, conforme demonstrado em diversas neoplasias em humanos e em animais. Vários estudos que avaliaram o AgNOR como marcador de proliferação celular no mastocitoma canino mostraram que altos índices de AgNOR correlacionam-se ao aumento da mortalidade, metástase e recidiva local (BOSTOCK et al., 1989; SIMÕES et al., 1994). Webster et al. (2007) mostraram que cães com mastocitoma que apresentaram contagem de AgNOR igual ou superior a 54 tiveram menor sobrevida em relação aqueles com AgNOR abaixo de 54, sugerindo que tanto o AgNOR como o Ki-67 devam ser incorporados na rotina na avaliação de cães com mastocitoma. Este estudo concluiu também que tanto o AgNOR, como o PCNA e Ki-67 podem mutuamente fornecer informação complementar sobre o comportamento biológico dos mastocitomas, quando utilizados em conjunto, mas não se utilizados independentemente. Porém, no estudo conduzido anteriormente por Scase et al. (2006), foi demonstrado que diferentemente do Ki-67, a utilização do AgNOR como elemento prognóstico não foi capaz de predizer o comportamento biológico do mastocitoma, principalmente em relação aos mastocitomas de grau 2, não fornecendo informação prognóstica adicional além daquela já estabelecida pelo sistema de graduação histológica de Patnaik.

Dentre os quatro marcadores de proliferação celular citados anteriormente, 0 índice mitótico e a expressão da proteína Ki-67 são aqueles que apresentam maior valor prognóstico (ABBADIE et al., 1999; SCASE et al., 2006; ROMANSKI et al., 2007; WEBSTER et al., 2007; ELSTON et al., 2009; VASCELLARI et al., 2013).

Proteínas de manutenção de minicromossomo (MCMs) são marcadores de proliferação celular e foram relacionadas ao prognóstico em várias neoplasias humanas. Estas proteínas são essenciais durante o processo de replicação do DNA e sua expressão pode ser observada em todas as fases do ciclo celular (GONZALEZ et al., 2005). O trabalho de Bertolato et al. (2011) estudou a expressão da MCM7 por imunoistoquímica em cães com mastocitoma, concluindo que esta proteína é um bom marcador prognóstico. Sua expressão correlacionou-se à sobrevida, além de ser um fator prognóstico independente da graduação histológica, sugerindo um possível papel desta proteína para uma avaliação mais precisa dos mastocitomas de grau intermediário. 
Mutações no proto-oncogene c-kit são descritas em algumas neoplasias humanas, como na mastocitose sistêmica, leucemia e no tumor estromal gastrointestinal (GIST). A proteína KIT é um receptor tirosina quinase, produto do proto-oncogene c-kit, o qual é expresso em diversos tecidos, incluindo melanócitos, precursores eritróides, basófilos, cérebro, placenta, células de glioblastoma, células intersticiais de Cajal, células germinativas e mastócitos. O ligante para o receptor $\mathrm{KIT}$, fator de célula tronco ou stem cell fator (SCF), também conhecido por fator de crescimento de mastócito, promove diversos efeitos sobre os mastócitos, como proliferação, maturação, migração, degranulação, supressão da apoptose e adesão à fibronectina. O receptor KIT é composto por um domínio de ligação extracelular (codificado pelos exons 1 a 9 do gene c-kit), um domínio justamembrana ou transmembrânico regulatório negativo (exons 11 e 12) e um domínio citoplasmático tirosina quinase, que é separado por uma inserção de ligação ao ATP (trifosfato de adenosina) e um lobo fosfotransferase (exon 17). Diversas pesquisas identificaram a presença de mutações no domínio justamembrana do proto-oncogene c-kit em cerca de $15-40 \%$ dos mastocitomas caninos (LONDON et al., 1996; LONDON et al., 1999; MA et al., 1999; ZEMKE et al., 2002; KIUPEL et al., 2004; LETARD et al., 2008). London et al. (1999) mostraram que as mutações identificadas nas desordens de mastócitos em seres humanos, como por exemplo na mastocitose sistêmica, eram distintas daquelas observadas em cães com mastocitoma. Nesta espécie, foi identificada a presença de duplicação interna em tandem nos exons 11 e 12 do gene c-kit. Estas mutações resultaram na autofosforilação e ativação constitutiva do receptor KIT, na ausência do ligante SCF, ou seja, promoveu a proliferação descontrolada e a sobrevivência dos mastócitos independente da presença do fator de crescimento. Zemke et al. (2002) conduziram um estudo com 88 cães portadores de mastocitoma e demonstraram que existe uma relação entre o grau histológico da neoplasia e a presença de mutação, particularmente duplicações, no domínio justamembrana do c-kit. Eles não observaram mutações nos mastocitomas de grau 1 , enquanto que menos de $10 \%$ dos mastocitomas de grau 2 e quatro de seis mastocitomas de grau 3 exibiam mutações no c-kit, indicando que a avaliação de mutação no c-kit por PCR (Polimerase Chain Reaction) é um bom exame para predizer o comportamento biológico desta neoplasia. Os autores sugerem ainda que o gene c-kit possa estar envolvido em parte no processo de carcinogênese do mastocitoma, sendo um potencial alvo terapêutico para os inibidores de tirosina 
quinase. Já num estudo retrospectivo com 47 cães portadores de mastocitoma, identificaram-se mutações no gene c-kit em $34 \%$ dos animais, sendo as mais comuns a duplicação interna em tandem nos exons 8 e 11. Identificou-se também outro tipo de alteração no gene c-kit, a deleção em determinadas regiões, mas o impacto desta mutação não foi elucidado. A presença de mutação no exon 11 foi significantemente associada à menor sobrevida (TAKEUCHI et al., 2012). A localização aberrante da proteína KIT em mastocitomas caninos também correlaciona-se a presença de mutações no gene c-kit. Kiupel et al. (2004) descreveram três padrões distintos de marcação, onde KIT I corresponde a neoplasias com marcação predominante em membrana citoplasmática, com mínima marcação citoplasmática; KIT II neoplasias com marcação citoplasmática intensa focal ou pontilhada e KIT III uma marcação citoplasmática difusa, obscurecendo outras características citoplasmáticas. Estes autores mostraram que neoplasias que apresentaram KIT padrão I não foram associadas com recidiva local e menor tempo de sobrevida, mas as neoplasias com padrão KIT II e KIT III foram associadas à um maior índice de recidiva local e menor sobrevida, confirmando que mastocitomas que apresentam marcação citoplasmática da proteína KIT possuem comportamento biológico mais agressivo. Isto pode ser explicado pelo papel que o KIT e seu ligante, o SCF, exercem no desenvolvimento dos mastócitos. O mecanismo exato pelo qual o aumento na expressão da proteína KIT leva à transformação maligna de mastócitos não está bem elucidado. Conforme sugerido por outros autores, a isoforma citoplasmática do receptor KIT pode ser ativada pelo SCF solúvel, ou pode conter mutações que o ativam constitutivamente, fatores estes que promovem a inibição da apoptose, adesão, migração e proliferação dos mastócitos. O estudo propõe a avaliação da proteína KIT por imunoistoquímica como ferramenta adicional no prognóstico do mastocitoma canino, sugerindo que mastocitomas tratados unicamente por cirurgia e que apresentem um padrão de marcação citoplasmático, estão associados à um maior índice de recidiva e menor sobrevida, necessitando portanto de terapia mais agressiva, como a radioterapia. Corroborando os resultados de Kiupel et al. (2004) e Preziosi et al. (2004a) mostraram uma forte correlação dos diferentes padrões de marcação da proteína KIT ao grau histológico $(P<0,00000)$, diferenciação celular $(P<, 00000)$ e morfologia nuclear $(P<0,0024)$. Mastocitomas de grau $2(n=11)$ apresentaram imunomarcação mais heterogênea, sendo 4 com padrão membranoso, 4 com padrão citoplasmático difuso e 3 citoplasmático difuso e 
perinuclear, refletindo a subjetividade da avaliação histológica dos tumores de grau 2, segundo a graduação de Patnaik.

Para mastocitomas de baixo grau, segundo a graduação de Kiupel ou de grau 2, segundo a graduação de Patnaik, sugere-se a realização de um painel de marcadores prognósticos, incluindo o Ki-67 como marcador de proliferação celular (utilizando como ponto de corte o valor de 23), avaliação da expressão da proteína KIT e da presença de mutação no gene c-kit, para então determinar o risco de metástase e selecionar o tratamento mais apropriado (PREZIOSI et al., 2004a; WEBSTER et al., 2007; WEBSTER et al., 2008; KIUPEL et al., 2011).

Strefezzi et al. (2009) reportaram a associação da morfometria nuclear à sobrevida de cães com mastocitoma cutâneo. Em seu estudo, a área nuclear média dos mastócitos neoplásicos foi avaliada e as neoplasias foram divididas em dois grupos morfometricamente distintos, de mastocitomas de baixo grau e de alto grau. Observou-se uma diferença na sobrevida média estatisticamente significante entre os dois grupos $(P=0.0011)$. Além disso, por meio desta técnica, foi possível também separar os cães com diagnóstico de mastocitoma de grau 2, segundo Patnaik, em dois grupos, sendo um com bom prognóstico e o outro com mastocitomas de comportamento biológico mais agressivo.

Amagai et al. (2013) sugerem que cães com múltiplos mastocitomas podem apresentar uma heterogeneidade nas duplicações internas em tandem no gene c-kit. De 12 cães avaliados, 2 apresentavam duplicação interna em tandem na lesão primária, mas não na secundária. O estudo propõe que a presença de mutação do gene c-kit deva ser investigada em mais de uma lesão dos pacientes que apresentam mastocitomas múltiplos a fim de estabelecer um melhor prognóstico e resposta à terapia com inibidores de tirosina quinase (ITK).

Similarmente, um recente trabalho realizou uma análise mutacional do gene c-kit em mastocitomas primários e metastáticos. Foram analisadas as lesões primárias e metastáticas de 21 cães portadores de mastocitoma cutâneo. Os exons 8, 9 e 11 do gene c-kit foram amplificados por PCR e sequenciados, e as características genéticas dos mastocitomas primários e metastáticos foram comparadas. Houve concordância de $100 \%$ na análise mutacional do gene c-kit nas lesões primárias e metastáticas, sugerindo que estes pacientes poderiam se beneficiar do uso dos inibidores de tirosina quinase (MARCONATO et al., 2014). 
A presença de aneuploidia também foi relacionada ao prognóstico em mastocitomas cutâneos caninos. Alterações no conteúdo de DNA nuclear foram determinadas por citometria de fluxo em diversas neoplasias humanas. Um estudo que avaliou 40 mastocitomas caninos por citometria de fluxo, identificou que mais de $70 \%$ das neoplasias eram diploides. O estudo não encontrou correlação entre a ploidia do mastocitoma e o grau histológico, localização e estadiamento clínico da doença. No entanto, observou-se uma diferença estatisticamente significante na ploidia dos tumores quando comparou-se animais em estágio clínico I com animais em estágios clínicos II a IV (segundo estadiamento da OMS) e uma tendência a menor sobrevida em cães com neoplasias aneuploides. Os autores sugerem que cães com neoplasias aneuploides devam receber tratamento adjuvante sistêmico além do tratamento local para melhor controle de metástases. Entretanto, a ploidia do DNA em mastocitomas cutâneos caninos não parece ser um fator prognóstico de alto impacto, quando comparado a outros elementos prognósticos (AYL et al., 1992).

$\mathrm{O}$ aumento da densidade microvascular intratumoral (DMVI) foi associado à mastocitomas de alto grau, à um maior grau de invasão da neoplasia, recidiva local, menor sobrevida e por isso, à um pior prognóstico. Este parâmetro foi avaliado por imunoistoquímica utilizando-se o marcador endotelial Fator VIII (fator de von Willebrand) em 32 mastocitomas cutâneos caninos por Preziosi et al. (2004 b). Os autores observaram diferença estatisticamente significante na DMVI entre os mastocitomas de grau 1 e grau $3(P=0,0002)$, entre mastocitomas moderadamente e altamente invasivos $(P=0,002)$ e entre neoplasias com diferentes índices mitóticos $(P=0,0046)$. Em relação à sobrevida, apenas o índice mitótico e a DMVI foram considerados fatores prognósticos independentes ( $P=0,00019)$.

A ocorrência de recidiva local após tratamento cirúrgico favorece um prognóstico reservado. No estudo de Thamm, Mauldin e Vail (1999), comparou-se a sobrevida de animais que apresentavam mastocitoma primário com animais que apresentavam recidiva do mastocitoma. A sobrevida média foi de 245 dias apenas no grupo que tinha recidiva, enquanto que naqueles que apresentavam a neoplasia primária a sobrevida média foi acima de 1695 dias. Os autores sugerem ainda que a quimioterapia com vimblastina e prednisona pode beneficiar os pacientes após uma cirurgia com margens comprometidas, diminuindo assim o risco de recidiva local.

A taxa de crescimento do mastocitoma foi relatada por Bostock et al. (1973) como um fator prognóstico também. Em seu estudo, $83 \%$ dos cães que 
apresentavam a neoplasia por um período de mais de 28 semanas previamente à cirurgia, atingiram uma sobrevida de pelo menos 30 semanas, enquanto que naqueles que portavam a neoplasia há menos de 28 semanas, este índice foi de apenas 25\%. Poggiani et al. (2012) também observaram que mastocitomas que exibiam maior tempo de evolução (média de 150 dias), foram posteriormente diagnosticados como mastocitomas de baixo grau.

A presença de sinais sistêmicos em animais portadores de mastocitoma, como anorexia, vomito, melena, ulceração gastrointestinal e outros sinais associados à degranulação de mastócitos estão relacionados a estágios mais avançados da doença, e por isso a um prognóstico mais reservado (MULLINS et al., 2006).

A expressão de BCL-2 e COX-2 foi investigada em mastocitomas cutâneos caninos por imunoistoquímica e por PCR quantitativo em tempo real (qRT-PCR) com o objetivo de avaliar o valor prognóstico destes marcadores (VASCELLARI et al., 2012). A família BCL-2 inclui proteínas pró-apoptóticas e anti-apoptóticas, como a BCL-2, que inibe a apoptose bloqueando a liberação do citocromo c. Uma superexpressão de BCL-2 pode predispor à transformação maligna e já foi relatada em diversas neoplasias. Estudos in vitro e em pacientes humanos que apresentam mastocitose mostraram um aumento na expressão da proteína BCL-2 nos mastócitos. No entanto, o mecanismo pelo qual a família de proteínas BCL-2 promove o desenvolvimento de uma neoplasia ainda não foi bem elucidado, mas acredita-se que estas proteínas permitem que as células sobrevivam por um tempo maior, acumulando consequentemente mais alterações genéticas (BALIGA; KUMAR, 2002). Já a ciclooxigenase-2 (COX-2) pertence à família das enzimas ciclooxigenases, que catalisam a conversão do ácido araquidônico em prostaglandina G2. Os mecanismos pelos quais a COX-2 contribui para o desenvolvimento de neoplasias incluem: inibição de apoptose celular, promoção da angiogênese tumoral, aumento da motilidade e capacidade de invasão das células neopláscias, atividade imunomoduladora e conversão de pró-carcinógenos em carcinógenos. A superexpressão de COX-2 já foi identificada em diversas neoplasias em cães, como carcinoma intestinal, carcinoma de células de transição, carcinoma mamário, carcinoma renal e carcinoma epidermóide (FOSSLIEN, 2000). O estudo mostrou que os níveis de RNAm do gene BCL-2 estavam significantemente mais elevados nos mastocitomas de graus 2 e 3 em comparação aos mastocitomas de grau 1, pela graduação de Patnaik, e que nestes casos, a sobrevida foi menor, 
concluindo que a expressão deste gene correlaciona-se ao prognóstico. No entanto, a expressão da proteína BCL-2 não correlacionou-se ao prognóstico, uma vez que não houve associação desta ao grau histológico das neoplasias. Já a proteína COX2 foi identificada em $78 \%$ dos mastocitomas. Entretanto não observou-se associação ao grau histológico das neoplasias. Os níveis de RNAm da COX-2 eram significantemente mais elevados nos mastocitomas, comparado ao controle (pele normal), mas também não foi identificada uma associação com o grau histológico, nem com a sobrevida (VASCELLARI et al., 2012). Strefezzi et al. (2012) demonstraram aumento da expressão da proteína pró-apoptótica Bax em mastocitomas de graus II e III, pela graduação de Patnaik, além da correlaçao com menor tempo de sobrevida após a cirurgia, indicando que a detecção de Bax é um fator preditivo da evolução da doença.

Amagai et al. (2013) realizaram um estudo avaliando o papel da proteína antiapoptótica MCL-1 em 4 linhagens de células de mastocitoma canino. Os autores sugerem que esta proteína pode contribuir para a sobrevivência dos mastócitos neoplásicos, além de estar envolvida com a resistência das células neoplásicas a diferentes drogas.

Boxers, Pugs, assim como outras raças braquicefálicas são descritas na literatura por terem uma tendência a desenvolverem mastocitomas de baixo a intermediário grau e consequentemente estão associadas à um melhor prognóstico (BOSTOCK, 1986; McNIEL; PRINK; O'BRIEN, 2004). London e Thamm (2013) referem que há evidências que cães da raça Sharpei exibem um pior prognóstico para a doença. $O$ estudo de Zemke et al. (2002) não encontrou relação entre raça e a presença de mutação no gene c-kit em cães portadores de mastocitoma.

A grande maioria dos estudos não reportam uma predisposição sexual ou uma associação do gênero à sobrevida nos mastocitomas cutâneos caninos (PATNAIK; EHLER; MacEWENN, 1984; BAKER-GABB; HUNT; FRANCE, 2003; LONDON; THAMM, 2013). Apenas um estudo europeu sugeriu um prognóstico mais favorável em fêmeas que receberam tratamento quimioterápico, do que em machos (GERRITSEN et al., 1998). No entanto, London e Thamm (2013) referem que o elevado número de fêmeas intactas na europa, diferentemente do que ocorre nos Estados Unidos, possa ter influenciado o resultado do estudo supra citado, permitindo um maior impacto estatístico dos hormônios sexuais no comportamento biológico do mastocitoma canino. Outros dois trabalhos pesquisaram a influência do 
gênero no mastocitoma canino, com resultados controversos. LaDue et al. (1998) afirmam que o gênero não influenciou o intervalo livre de doença e a sobrevida de animais com mastocitomas incompletamente excisados e tratados por radioterapia. Já White et al. (2011) afirmam que fêmeas castradas têm um maior risco de desenvolvimento da doença. Apesar de Elling e Ungemach (1982) terem identificado a presença de receptores de estrógeno e progesterona em mastocitomas caninos, o verdadeiro papel dos hormônios sexuais na etiopatogenia e comportamento biológico desta neoplasia permanece indefinido (LONDON; THAMM, 2013).

A E-caderina é uma molécula de adesão presente na membrana plasmática expressa principalmente em células epiteliais. A perda da expressão desta molécula foi relatada durante o processo de progressão tumoral em diversas neoplasias epiteliais e no melanoma, em humanos e em cães e este fenômeno está associado à um pior prognóstico (POLTON et al., 2007). Mackowiak et al. (2012) investigaram a expressão de E-caderina em mastocitomas cutâneos caninos por imunoistoquímica e observaram a translocação desta proteína, que passou a ser expressa no citoplasma e no núcleo em mastocitomas de graus 1, 2 e 3. Demonstrou-se também uma diminuição ou mesmo perda da expressão da proteína nos mastocitomas pouco diferenciados, sugerindo a importância da adesão celular no comportamento biológico desta neoplasia.

A triptase é uma das proteases mais comumente encontradas nos grânulos dos mastócitos. Sua identificação por exame imunoistoquímico demonstrou ter alta sensibilidade e especificidade para mastócitos (WALLS et al., 1990). Kiupel et al. (2004) pesquisaram a expressão da triptase em 98 mastocitomas caninos e identificou 3 diferentes padrões de expressão desta protease: citplasmática difusa, citoplasmática pontilhada ou focal e pouca ou nenhuma marcação citoplasmática. No entanto, os autores não observaram correlação entre os diferentes padrões de expressão da triptase com o tempo livre de doença, recidiva local ou sobrevida.

A degradação da matriz extracelular, assim como a angiogênese vascular são fatores essenciais para o crescimento e progressão tumoral. As metaloproteinases de matriz (MMP) estão envolvidas em diversos processos fisiológicos, mas também são produzidas por células neoplásicas e favorecem a invasão tumoral através da proteólise extracelular. As MMPs são controladas por tecidos inibidores de metaloproteinases (TIMPs). O fator de crescimento endotelial vascular (VEGF) é o principal regular da angiogênese tumoral, garantindo o aporte de oxigênio e 
nutrientes para as células neoplásicas. Diversos estudos em cães já demonstraram a correlação entre o grau histológico da neoplasia e o aumento na expressão de VEGF. Giantin et al. (2012) verificaram a expressão de MMPs, TIMPs e VEGF em mastocitomas caninos, por imunoistoquímica e por qRT-PCR. Os autores verificaram um aumento da quantidade de RNAm da MMP-9 e do VEGF-A e diminuição no RNAm do TIMP-2 nos mastocitomas moderadamente e pouco diferenciados. Observou-se também um aumento na atividade das MMP-2 e MMP-9 com o aumento do grau histológico da neoplasia, concluindo-se que os marcadores MMP9, TIMP-2 e VEGF-A são considerados possíveis indicadores de malignidade e potenciais alvos terapêuticos.

O gene p53 é um gene supressor tumoral que exerce um importante papel no controle do ciclo celular, manutenção da estabilidade genômica e na morte celular por apoptose. Mutação neste gene é uma das alterações genéticas mais comumente associada ao desenvolvimento de diversos tipos de câncer em humanos. Jaffe et al. (2000) avaliaram a expressão deste gene em 126 mastocitomas cutâneos caninos, por imunoistoquímica. Houve uma diferença significante na porcentagem de células positivas para p53 de acordo com os diferentes graus histopatológicos $(P=0,0005)$, sendo que a maior porcentagem foi observada nos mastocitomas de grau 3 , pela graduação de Patnaik. No entanto, a detecção do p53 em mastocitomas caninos não demonstrou ter valor prognóstico em relação ao tempo livre de doença e a sobrevida. Resultado semelhante foi encontrado no estudo conduzido por Wu et al. (2006). Neste trabalho, além da expressão da proteína p53, os pesquisadores estudaram também a expressão da proteína Mdm2 em mastocitomas cutâneos caninos, a qual apresentou-se superexpressa, sendo que nos mastocitomas de grau 3, pela graduação de Patnaik, observou-se moderada à marcada reatividade nuclear, sugerindo que a expressão desta proteína correlaciona-se ao grau histológico da neoplasia e que ela pode exercer um papel na carcinogênese do mastocitoma. Não foi identificada uma correlação entre a expressão de Mdm2 e p53, indicando que a expressão da proteína Mdm2 é regulada por mecanismos independentes do p53. 


\subsubsection{Tratamento}

O tratamento do mastocitoma cutâneo em cães dependerá da apresentação clínica da doença e deve levar em consideração a presença ou ausência de fatores prognósticos. Diversas modalidades terapêuticas são descritas para o mastocitoma, sendo as principais: cirurgia, quimioterapia, inibidores de tirosina quinase e radioterapia (WELLE et al., 2008; BLACKWOOD et al., 2012; LONDON; THAMM, 2013).

Cirurgia com margens amplas é o tratamento de escolha para o mastocitoma cutâneo canino. Recomenda-se a realização de margens cirúrgicas de $3 \mathrm{~cm}$ em lateralidade e um plano tecidual em profundidade (incluindo a fáscia muscular ou a musculatura) para o adequado controle local da doença (GOVIER, 2003; THAMM; VAIL, 2003). Mas os estudos de Simpson et al. (2004) e Fulcher et al. (2006) referem que margens cirúrgicas de $2 \mathrm{~cm}$ em lateralidade são suficientes no tratamento dos mastocitomas, principalmente naqueles de baixo grau histológico. Um outro estudo mais recente refere que a exérese de mastocitomas de grau 1 ou 2 , pela graduação de Patnaik, medindo de 2 a $3.1 \mathrm{~cm}$, com margens laterais de pelo menos $1 \mathrm{~cm}$ e margens profundas de $4 \mathrm{~mm}$ não resultaram em recidiva local (SCHULTHEISS et al., 2011).

Para mastocitomas de baixo a intermediário grau, a cirurgia com margens amplas promove o controle local da doença. Diversos estudos reportam que após remoção cirúrgica completa de mastocitomas de grau 2, houve recidiva em apenas $5-11 \%$ dos casos, com metástase à distância em 5-22\% dos casos (CHAFFIN; THRALL, 2002; SFILIGOI et al., 2005; FULCHER et al., 2006; MULLINS et al., 2006; SEGUIN et al., 2006).

Já para mastocitomas incompletamente excisados, ou localizados numa região anatômica desfavorável para um procedimento cirúrgico com margens amplas, como extremidades, região perianal e região de face, ou mesmo para mastocitomas de alto grau, recomenda-se a associação de outras modalidades terapêuticas, como a radioterapia e/ou quimioterapia (WELLE et al., 2008; BLACKWOOD et al., 2012; LONDON; THAMM, 2013).

A radioterapia pode ser utilizada como tratamento único nestes casos, ou em associação ao tratamento cirúrgico. É indicada como tratamento único para 
mastocitomas de baixo ou intermediário grau, que sejam muito volumosos, não permitindo um procedimento cirúrgico. No entanto, deve-se considerar o risco de degranulação de mastócitos induzida pela radioterapia, além da presença de células neoplásicas radioresistentes em formações mais volumosas (BLACKWOOD et al., 2012). Um estudo avaliou 35 cães portadores de mastocitoma localizados em membros ou na região da cabeça, onde uma cirurgia adequada não era possível. Estes animais foram tratados com prednisolona oral $\left(40 \mathrm{mg} / \mathrm{m}^{2}\right.$ diariamente, por 14 dias antes da radioterapia e manutenção durante e após o tratamento na dose de $20 \mathrm{mg} / \mathrm{m}^{2}$ diariamente), associada a radioterapia com acelerador linear (4 sessões de 8 Gray (Gy) com intervalos de 7 dias). 12 cães apresentaram resposta completa, 19 cães resposta parcial, 2 cães doença estável e 2 cães progressão da doença. $O$ intervalo livre de progressão da doença foi de 1031 dias. Os autores concluíram que o uso da radioterapia associada à prednisolona foi eficaz no controle de mastocitomas inoperáveis (DOBSON et al., 2004).

No entanto, a principal recomendação da radioterapia é como tratamento adjuvante, após a cirurgia, quando não foi possível obter margens cirúrgicas livres. A associação de cirurgia com radioterapia para mastocitomas de baixo ou intermediário grau promove controle local da doença por 2 anos em $85-95 \%$ dos casos (AL-SARRAF et al., 1996; LaDUE et al., 1998; POIRIER et al., 2006). Frimberger et al. (1997) avaliaram o uso da radioterapia de ortovoltagem e de megavoltagem como tratamento único em 37 cães com mastocitomas moderadamente diferenciados e incompletamente excisados e obtiveram controle local da doença por 1 ano em $97 \%$ dos casos, e por 3 anos em 93\% dos casos. Os protocolos de radioterapia utilizam doses que variam de $40-57 \mathrm{~Gy}$, administrada em doses médias de $3 G y$ por sessão, realizadas diariamente ou 3 vezes por semana (LaDUE et al., 1998; CHAFFIN; DONALD; THRALL, 2002; DOBSON et al., 2004; WELLE et al., 2008).

O índice de recidiva local após exérese cirúrgica incompleta (margens cirúrgicas comprometidas) varia entre os estudos, mas todos mostram este fator como um elemento prognóstico negativo, resultando em menor sobrevida dos pacientes. (BOSTOCK et al., 1989; THAMM; MAULDIN; VAIL, 1999; MURPHY et al., 2004). Nestes casos, recomenda-se uma nova cirurgia para ampliação de margens, quando possível, ou indica-se a radioterapia (LONDON; THAMM, 2013). 
Alguns autores sugerem também a radiação profilática de linfonodos regionais nos mastocitomas de alto grau (HANH; KING; CARRERAS, 2004; THAMM; TUREK; VAIL, 2006). O estudo de Chaffin e Thrall (2002) avaliou a eficácia da radioterapia em 19 cães tratados por cirurgia, seguido de radioterapia no local do tumor primário e no linfonodo regional, associado à terapia oral com prednisolona. Todos os cães apresentavam metástase nos linfonodos irradiados. A sobrevida média livre de doença destes pacientes foi de 1240 dias. No entanto, Poirier et al. (2006) referem que não há vantagem na radiação profilática de linfonodos regionais de mastocitomas de grau 2, pela graduação de Patnaik, não encontrando diferença na sobrevida destes animais, quando comparados aqueles onde não foi realizada a radiação profilática. Segundo Marconato et al. (2008), animais com diagnóstico citológico positivo para metástase em linfonodo regional podem beneficiar-se com linfadenectomia, associada à quimioterapia adjuvante, se necessário. Já Ladue et al. (1996) recomendam a radiação profilática do linfonodo regional em cães com mastocitoma de grau intermediário, independentemente do resultado da citologia. Estes autores relataram ainda que dos 42 cães que receberam tratamento radioterápico do linfonodo, 2 evoluíram com progressão da doença, concluindo que a presença de metástase em linfonodo em cães diagnosticados com mastocitoma de grau 2 é um evento clinicamente significante. Recentemente, o estudo de Baginski et al. (2014) avaliou o prognóstico de cães portadores de mastocitoma de grau 2. Estes pesquisadores concluíram que a linfadenectomia nos pacientes diagnosticados com metástase em linfonodo regional proporcionou aumento significante na sobrevida $(P=0,007)$ em relação aqueles que apresentavam metástase mas não passaram por linfadenectomia.

A quimioterapia é indicada em 3 situações distintas: como tratamento adjuvante à cirurgia, para prevenir metástases a distância, principalmente tratandose de mastocitomas de alto grau, ou naqueles moderadamente diferenciados, mas com fatores prognósticos negativos, como índice mitótico e Ki-67 elevados, presença de metástase em linfonodo regional ou mastocitoma localizado em região mucocutânea; como tratamento neoadjuvante, previamente à cirurgia ou radioterapia, com o objetivo de citorredução para facilitar ambos os procedimentos e para tratar doença microscópica residual, quando uma nova cirurgia não é possível ou quando a radioterapia não for disponível. As principais drogas utilizadas são a 
prednisona, vimblastina, lomustina e ciclofosfamida (THAMM; VAIL; TUREK, 2006; BLACKWOOD et al., 2012; LONDON; THAMM, 2013).

O uso da prednisona como agente único, ou em combinação com agentes quimioterápicos para o tratamento do mastocitoma foi descrito em diversos estudos, com doses de 1,0-2,2mg/kg, diariamente, por períodos pré-determinados. Observase uma reposta de cerca de $20 \%$ quando utilizada como agente único, e de curta duração (McCAW et al., 1994; THAMM; MAULDIN; VAIL, 1999; DOBSON et al., 2004; HAYES et al., 2007; STANCLIFT; GILSON, 2008). Takahashi et al. (1997) descreveram a ação dos corticosteroides como inibidores da proliferação celular nos mastocitomas caninos e indutores de apoptose das células neoplásicas in vitro. Apesar da sua ampla utilização nos protocolos quimioterápicos para tratamento do mastocitoma canino, recentemente Matsuda et al. (2011) demonstraram que a resposta do mastocitoma ao corticosteroide é dependente da expressão de receptores de glicocorticoides nas células neoplásicas. Neste estudo, os autores observaram que as neoplasias com baixa expressão deste receptor apresentavam resistência ao tratamento com prednisona oral.

A vimblastina é um quimioterápico alcaloide da vinca, sendo uma das drogas mais empregadas no tratamento do mastocitoma canino (LONDON; THAMM, 2013). Um estudo avaliou a reposta em cães portadores de mastocitoma de alto grau, após tratamento cirúrgico, tratados com vimblastina e prednisona. $70 \%$ dos animais apresentaram 2 anos de sobrevida livre de doença (HAYES et al., 2007), tempo superior aos 278 dias relatados no estudo de Murphy et al. (2004) que avaliaram cães com mastocitomas pouco diferenciados tratados apenas por cirurgia. Já no estudo de Thamm et al. (2006) animais com mastocitoma de alto grau, tratados por cirurgia, seguido de radioterapia e quimioterapia com vimblastina e prednisona apresentaram sobrevida de 1374 dias. Camps-Palau et al. (2007) recomendam o uso de quimioterapia com vimblastina, ciclofosfamida e prednisona para cães com mastocitoma de alto grau, ou que apresentem recidiva ou metástase. Neste estudo, a sobrevida dos pacientes tratados com este protocolo foi de 2092 dias.

A lomustina é um quimioterápico alquilante, que pode ser empregado como agente único, ou em combinação com a vimblastina e a prednisona. Rassnick et al. (1999) avaliaram o uso da lomustina como agente único para citorredução, em 21 cães portadores de mastocitoma, reportando $37 \%$ de resposta parcial e $6 \%$ de resposta completa, com duração mediana de resposta de 79 dias. Já em 
combinação com a vimblastina e a prednisona, observa-se $32-35 \%$ de resposta parcial e 24-29\% de resposta completa, com duração mediana de reposta de 120 141 dias (COOPER et al., 2009; RASSNICK et al., 2010).

Lejeune et al. (2013) (no prelo) ${ }^{9}$ num estudo recente, recomendaram o uso da quimioterapia com vimblastina, lomustina e prednisona para cães portadores de mastocitoma de grau 2, pela graduação de Patnaik, que apresentam metástase em linfonodo regional. Os animais apresentaram 1359 dias de sobrevida média. Os autores evidenciaram também que cães tratados apenas por cirurgia e quimioterapia tiveram uma sobrevida menor (1103 dias) em relação aqueles que receberam adicionalmente tratamento radioterápico (2056 dias).

A dose de vimblastina utilizada na maioria dos estudos é de $2 \mathrm{mg} / \mathrm{m}^{2}$, mas alguns autores reportaram doses mais altas, chegando até a $3,5 \mathrm{mg} / \mathrm{m}^{2}$. A principal toxicidade encontrada foi mielossupressão e sinais gastrointestinais, como êmese e diarreia (CAMPS-PALAU et al., 2007; HAYES et al., 2007; RASSNICK et al., 2008; VICKERY et al., 2008). Já a lomustina é utilizada nas doses de $59-90 \mathrm{mg} / \mathrm{m}^{2}$ e tem como efeitos adversos a mielossupressão, caracterizada principalmente por neutropenia e trombocitopenia, e hepatotoxicidade (RASSNICK et al., 1999; COOPER et al., 2009; RASSNICK et al., 2010; BLACKWOOD et al., 2012).

Clorambucil, um agente alquilante, também foi reportado para o tratamento de mastocitomas inoperáveis, em associação com a prednisolona, por Taylor et al. (2005). Este estudo avaliou 21 cães, sendo que 14\% apresentou resposta completa, $24 \%$ resposta parcial, $43 \%$ doença estável e $19 \%$ progressão da doença, com $38 \%$ de resposta global. A sobrevida média dos animais foi de 143 dias, semelhante aos 145 dias descritos no estudo de Camps-Palau et al. (2007) onde cães com doença macroscópica foram tratados com vimblastina ciclofosfamida e prednisona. Outra vantagem do protocolo foi a ausência de efeitos colaterais.

Outros quimioterápicos descritos para o tratamento do mastocitoma canino, mas com respostas inferiores são vincristina ( $7 \%$ de resposta) e vinorelbine (13\% de resposta) (McCAW et al., 1997; GRANT et al., 2008). L-Asparaginase e

\footnotetext{
${ }^{9}$ LEJEUNE, A.; SKORUPSKI, K.; FRAZIER, S.; VANHAEZEBROUCK, I.; REBHUN, R. B.; REILLY, C. M.; RODRIGUEZ, C. O. Aggressive local therapy combined with systemic chemotherapy provides long-term control in grade II stage 2 canine mast cell tumour: 21 cases (1999-2012). Veterinary and Comparative Oncology. (Aceito para publicação em 2013).
} 
doxorrubicina também foram reportadas, mas não há comprovação clínica de sua eficiência (MACY, 1985; O'KEEFE, 1990).

O uso de inibidores de tirosina quinase, como o masitinib e o toceranib, foi reportado por Hahn et al. (2008) e London et al. (2009), respectivamente, para o tratamento do mastocitoma canino. Os receptores tirosina quinase são responsáveis por ativarem a proliferação, diferenciação e sobrevivência da célula quando estimulados por seu ligante. No entanto, uma disfunção nestes receptores foi associada ao desenvolvimento de diversos tipos de câncer, incluindo o mastocitoma canino, além de estarem envolvidos também no processo de angiogênese e metástase. Os inibidores de tirosina quinase são pequenas moléculas capazes de bloquear a atividade destes receptores por inibição competitiva do sítio de ligação do ATP (MARTIN; ARGYLE, 2013).

O estudo de London et al. (2009) mostrou que o toceranib é capaz de bloquear também o receptor do fator de crescimento derivado de paquetas (PDGFR) e o receptor do fator de crescimento endotelial vascular (VEGFR). O tratamento com toceranib (Palladia®, Pfizer Animal Health) como agente único mostrou-se eficaz em mastocitomas recorrentes de graus II ou III, com ou sem comprometimento de linfonodo regional. Observou-se uma melhora estatisticamente significante na taxa de resposta objetiva dos animais tratados $(n=145)$, em relação ao grupo placebo. A taxa de resposta objetiva foi de $42,8 \%$ ( $n=62$, sendo 21 respostas completas e 41 respostas parciais), além de 16 animais que exibiram doença estável por mais de 10 semanas, totalizando uma taxa de resposta objetiva de $60 \%$. A presença de mutação do gene c-kit e a ausência de metástase em linfonodo regional foram associadas à uma maior resposta objetiva. Cães com mastocitoma de grau 2 e aqueles que não apresentavam metástase em linfonodo tiveram maior sobrevida livre de doença. Este estudo não encontrou associação entre presença de mutação no gene c-kit e duração da resposta ao tratamento ou ao tempo de sobrevida livre de doença. Os efeitos colaterais mais comumente observados foram vômito, diarreia, hematoquezia, neutropenia e perda de peso, mas foram controlados através do ajuste de doses e tratamento de suporte.

Já o estudo de Hahn et al. (2008) avaliou a eficácia do masitinib (Masivetß, AB Science) em mastocitomas inoperáveis ou recorrentes, de graus 2 ou 3, sem comprometimento de linfonodo regional ou metástase à distância, que foram ou não previamente tratados. O estudo mostrou que esta droga promoveu um aumento 
significante no tempo livre de doença nos animais tratados em relação aos animais do grupo placebo, principalmente quando utilizado como tratamento de primeira linha. O masitinib promoveu também um aumento na sobrevida global naqueles animais que apresentavam mutação do gene c-kit. A medicação foi bem tolerada, com efeitos adversos leves ou moderados, sendo os mais frequentes vômito e diarreia.

Isotani et al. (2008) avaliaram a ação do imatinib no tratamento de 21 cães com mastocitomas inoperáveis, onde $48 \%$ dos animais beneficiaram-se com 0 tratamento e 5 cães que possuíam mutação no exon 11 do gene c-kit apresentaram resposta, sendo 1 com remissão completa e 4 com remissão parcial da doença. No entanto ainda não há estudos avaliando a farmacocinética desta droga em cães (LONDON; THAMM, 2013).

A combinação de terapia com toceranib em dias alternados e doses reduzidas de vimblastina $\left(1,6 \mathrm{mg} / \mathrm{m}^{2}\right)$ quinzenalmente evidenciou uma resposta objetiva de $71 \%$ em cães portadores de mastocitoma, sugerindo uma possível ação sinérgica entre estas duas drogas (ROBAT et al., 2012).

Um estudo avaliou a combinação de toceranib com prednisona e radioterapia hipofracionada em cães com mastocitomas inoperáveis ou metastáticos. A resposta global foi de $76,4 \%$, sendo que $58,8 \%$ dos cães apresentaram resposta completa e $17,6 \%$ resposta parcial. A melhor resposta ao tratamento foi observada em 32 dias em média. O tempo livre de doença foi de 316 dias, e a sobrevida média não foi alcançada (374 dias em média de acompanhamento). Esta resposta foi superior àquela observada com tratamento único com toceranib, sugerindo que esta associação pode ser eficaz no controle de mastocitomas inoperáveis (CARLSTEN et al., 2012).

Outros tratamentos descritos, porém menos empregados são a crioterapia, uso de corticosteroides ou água deionizada intralesional, terapia fotodinâmica e eletroquimioterapia (EQT) (KRAHWINKEL, 1980; FRIMBERGER et al., 1998; SPUGNINI et al., 2011).

A crioterapia e a terapia fotodinâmica podem ser utilizadas para mastocitomas menores que $1 \mathrm{~cm}$, no entanto estes procedimentos podes desencadear a degranulação dos mastócitos. Por isso não são modalidades terapêuticas aplicadas na rotina, dando-se preferência ao tratamento cirúrgico (KRAHWINKEL, 1980; FRIMBERGER et al., 1998; BLACKWOOD et al., 2012). O uso de corticosteroide 
intralesional e água deionizada também foram reportados (MACY, 1986; NEYENS et al., 2004) mas faltam estudos clínicos randomizados em grandes populações de animais para comprovar a eficácia destes tratamentos, além dos mesmos impossibilitarem uma adequada avaliação de margens no histopatológico (NEYENS et al., 2004; WELLE et al., 2008; BLACKWOOD et al., 2012). No entanto, Brocks et al. (2008), realizaram um estudo randomizado, prospectivo, duplo-cego, com grupo controle e mostraram que o uso de água deionizada não reduziu a incidência de recidiva local em cães com margens comprometidas após o tratamento cirúrgico do mastocitoma cutâneo. Já a EQT consiste na administração local de pulsos elétricos de alta intensidade, que promovem a criação de poros transitórios e reversíveis na membrana da célula, facilitando a penetração de um agente citotóxico. Um estudo avaliou 28 cães que exibiam margens comprometidas após exérese do mastocitoma primário e foram submetidos à EQT. Foram realizadas 2 sessões, com intervalos semanais e utilizou-se a bleomicina como quimioterápico intralesional no local da cicatriz cirúrgica e $1 \mathrm{~cm}$ ao redor. A taxa de resposta global foi de $85 \%$ e não foi atingida a mediana da sobrevida global ao final do estudo (sobrevida mediana estimada em 52,7 meses) (SPUGNINI et al., 2006). Kodre et al. (2009) sugerem que a EQT pode ser um tratamento alternativo para mastocitomas pequenos $\left(2,9 \mathrm{~cm}^{3} \mathrm{em}\right.$ média) localizados em regiões onde uma cirurgia com margens amplas não seja possível. Em outro trabalho, Spugnini et al. (2011) demonstraram a eficácia da EQT, utilizando desta vez a cisplatina intralesional como agente citotóxico, para o controle de mastocitomas incompletamente excisados em 37 cães. Destes animais, 18 apresentavam doença macroscópica e 19 apenas a cicatriz cirúrgica. Os animais receberam 2 aplicações de EQT, com intervalo de 1 ou 2 semanas. Durante um período de 6 anos de acompanhamento, em 29 cães não houve evidência de recidiva do mastocitoma, 6 apresentaram recidiva e apenas 2 vieram a óbito, sendo um relacionado à doença. O tempo médio estimado para recidiva local foi de 1200 dias, sugerindo que a EQT é uma modalidade terapêutica eficaz no controle de mastocitomas incompletamente excisados, sendo uma alternativa de baixo custo em relação a outras terapias.

Tratamento de suporte para evitar possíveis efeitos colaterais decorrentes da liberação de histamina incluem antagonistas dos receptores $\mathrm{H} 1$, como a difenidramina (2-4mg/kg, por via oral a cada 12 horas) e antagonistas dos receptores $\mathrm{H} 2$, como a cimetidina ( $4-5,5 \mathrm{mg} / \mathrm{kg}$ a cada 8 horas) ou a ranitidina ( $2-4 \mathrm{mg} / \mathrm{kg}$ a 
cada 12 horas), ou mesmo o omeprazol (0,5 - 1mg/kg a cada 24 horas), um inibidor da bomba de prótons, na prevenção e tratamento de úlceras gastrointestinais. $O$ sucralfato (0,5 - $1 \mathrm{~g}$ a cada 8 horas) também é indicado, principalmente quando já estiver instalado o quadro de úlcera gástrica ou duodenal. Estes agentes são recomendados na presença sinais sistêmicos, ou previamente a situações que possam levar à degranulação de mastócitos, como por exemplo manipulação da neoplasia no trans-cirúrgico ou radioterapia em mastocitomas volumosos (THAMM; VAIL, 2007; BLACKWOOD et al., 2012).

\subsection{LINFONDO SENTINELA}

\subsubsection{Importância do linfonodo sentinela}

Linfonodo sentinela (LS) é o primeiro linfonodo a receber a drenagem linfática de uma neoplasia. Este termo foi citado inicialmente em 1960 por Gould e colegas no tratamento cirúrgico da neoplasia de glândula parótida. Em 1977, Cabanas reportou a importância do mapeamento linfático por linfangiografia e identificação do LS em casos de câncer peniano, mostrando que o status do LS era um fator preditivo na sobrevida. Mas foi em 1992 que Morton e colaboradores descreveram o conceito de LS num estudo com pacientes portadores de melanoma cutâneo e posteriormente, Giuliano et al. (1994), em mulheres com câncer de mama, demonstrando diferentes técnicas para a detecção do LS.

A identificação e biópsia do LS já é um procedimento bem estabelecido no tratamento cirúrgico principalmente do carcinoma mamário e do melanoma em humanos. Caso o LS esteja livre de metástase, admite-se que os outros linfonodos da cadeia também estão. Por outro lado, o comprometimento do LS por células neoplásicas pode indicar o acometimento de outros linfonodos da cadeia, e isto impactará diretamente na extensão do procedimento cirúrgico. Diversas técnicas são descritas na literatura para a identificação do LS, dentre elas, a linfocintilografia, que consiste na aplicação de um radiofármaco, associado ou não à utilização de corantes (como o azul patente ou o azul de metileno) (BONNEMA; VAN DE VELDE, 
2002). Alguns autores já demonstraram que existe indicação para adaptação destas técnicas na medicina veterinária também, conforme demonstrado em alguns estudos. Patsikas et al. (2006) utilizaram a linfografia para estudo da drenagem linfática da glândula mamária em cadelas, através da radiografia, após injeção de um meio de contraste na região ao redor dos mamilos das glândulas mamárias. Já Pereira et al. (2008) reportaram o estudo da drenagem linfática da glândula mamária em cadelas através da linfocitilografia, utilizando como meio de contraste um radiofármaco (Tecnécio-99), aplicado ao redor do mamilo nas glândulas mamárias. Aquino et al. (2012) realizaram um estudo para localizar o LS da região da vulva em cadelas, no qual utilizou-se um corante azul patente, associado a injeção de tecnécio-99, por via intradérmica na comissura anterior da vulva. O estudo concluiu que esta técnica de localização de LS, que é amplamente utilizada em mulheres com câncer de mama, foi eficaz também na detecção do LS em cadelas.

O status do LS é descrito como um dos fatores prognósticos mais importantes em diversas neoplasias humanas, como no câncer de cabeça e pescoço, gástrico, colorretal, colo de útero, mama, carcinoma pulmonar primário e melanoma (MERIC et al., 2000; KANG et al., 2011; LIAO et al, 2012; JAWAD et al., 2013; WANG et al., 2013; LI DESTRI et al., 2014).

$\mathrm{Na}$ veterinária também foi reportado como fator prognóstico relevante em neoplasias mamárias, melanoma oral, carcinoma pulmonar primário, osteossarcoma, sarcoma de células sinoviais, mastocitoma, dentre outras neoplasias (OLGIVIE et al., 1989; VAIL et al., 1994; McNIEL et al., 1997; HERRING et al., 2002; KIRPENSTEIJN et al., 2002; HILLERS et al., 2005; MURPHY et al., 2006; BERGMAN, 2007; SZCZUBIAL; LOPUSZYNSKI, 2011). No entanto, há poucos estudos descrevendo técnicas de identificação e biópsia do LS em medicina veterinária, principalmente devido à escassez de estudos abordando os padrões de drenagem linfática em animais domésticos, desconhecimento da importância clínica do LS, morbidade associada à linfadenectomia e falta de treinamento e equipamentos necessários para a identificação e exérese do LS (TUOHY et al., 2009).

Um estudo com 51 cadelas com carcinoma mamário correlacionou a sobrevida dos animais com a presença de metástase em linfonodo regional. $O$ índice de metástase variou conforme a histologia da neoplasia, com $38,46 \%$ de metástase nos carcinomas complexos e $56,67 \%$ nos carcinomas mamários simples. Cadelas que não apresentavam metástase tiveram 19,03 meses de sobrevida, enquanto que 
aquelas que tinham micrometástase (foco de células neopláscias de 0,2 a $2 \mathrm{~mm}$ de diâmetro) e metástases > 2 mm em linfonodo tiveram 15,76 e 8,29 meses de sobrevida (SZCZUBIAL; LOPUSZYNSKI, 2011). Yamagami et al. (1996) também observaram menor sobrevida em cadelas com metástase em linfonodo regional de carcinoma mamário, onde apenas $36 \%$ dos animais que apresentavam metástase tiveram sobrevida de 2 anos, em comparação à 94\% daqueles que não tinham metástase.

Williams e Packer (2003) relataram que de 100 cães com melanoma oral, 70\% apresentava metástase em linfonodo regional. Smedley et al. (2011) descreveram a metástase linfática como um fator prognóstico negativo nas neoplasias melanocíticas de cavidade oral, lábio, cutâneas e dígito.

Cães com carcinoma pulmonar primário e metástase em linfonodo regional apresentam sobrevida e tempo livre de doença significantemente menores (60 dias), em relação a cães com linfonodo negativo (365 dias). Um estudo mostrou que a (OLGIVIE et al., 1989; McNIEL et al., 1997). Das neoplasias pulmonares caninas, $71 \%$ apresentam embolização vascular ou linfática e 23\% metástase para linfonodos hilares (GRIFFEY et al., 1998).

Hillers et al. (2005) demonstraram que apesar do índice de metástase linfática ser baixo em cães com osteossarcoma apendicular $(4,4 \%)$, a presença de metástase correlacionou-se de forma significante com a sobrevida (318 dias em cães com linfonodo negativo e 59 dias apenas nos cães com linfonodo metastático).

Já no mastocitoma, dados compilados a partir de 21 estudos referem que o índice de metástase para linfonodos regionais é de 76\% (HOTTENDORF; NIELSEN, 1968). Estudos mais recentes reportam de 5-45\% a taxa de metástase linfática nos mastocitomas de grau 2 (SEGUIN et al., 2001; WEISSE et al., 2002; SEGUIN et al., 2006) e 55-96\% nos mastocitomas de grau 3 (HOTTENDORF; NIELSEN, 1967; BOSTOCK, 1973; PATNAIK; EHLER; MACEWEN, 1984; THAMM; VAIL, 2007). No estudo de Thamm et al. (1999), metástase linfática foi reportada em 53,6\% dos 41 cães avaliados (18 cães apresentavam mastocitoma moderadamente diferenciado e 23 cães, mastocitoma pouco diferenciado). Já os mastocitomas subcutâneos possuem taxa de metástase inferior a 4\% (THOMPSON et al., 2011a). Conforme citado anteriormente, a presença de metástase em linfonodo é um fator prognóstico relevante, associando-se à menor sobrevida (THAMM; MAULDIN; VAIL, 1999; GIEGER et al., 2003; CAHALANE ET AL., 2004; SFILIGOI et al., 2005; MURPHY et 
al., 2006; THAMM et al., 2006; MARCONATTO et al., 2008; WELLE et al., 2008; KRICK et al., 2009; HUME et al., 2011; BLACKWOOD et al., 2012; WORLEY, 2012; WEISHAAR et al., 2014 (no prelo $\left.)^{10}\right)$. Takeuchi et al. (2013) avaliaram o valor prognóstico da metástase em linfonodo regional, além da graduação histopatológica de Patnaik e Kiupel e da presença de mutação no gene c-kit. Ao final do estudo, concluiu-se que apenas o sistema de graduação proposto por Kiupel e a presença de metástase em linfonodo foram considerados elementos prognósticos independentes na sobrevida. Sfiligoi et al. (2005) referem também que a presença de metástase no momento do diagnóstico associa-se significantemente à menor sobrevida ( $P=0.002$ ). No entanto, o recente estudo de Baginski et al. (2014) não observou diferença na sobrevida de cães portadores de mastocitoma de grau 2, com e sem metástase em linfonodo regional, assim como dois outros estudos que também não encontraram correlação entre metástase linfática e sobrevida (LaDUE et al., 1998; THAMM; MAULDIN; VAIL, 1999). Mas Baginski et al. (2014) referem que o resultado obtido em seu estudo deve ser interpretado com cautela pois diferentes tratamentos adjuvantes foram empregados e isto pode ter interferido na sobrevida dos pacientes. Apesar disto, Chaffin e Thrall (2002) e Welle et al. (2008) afirmam que a presença de metástase em linfonodos regionais de mastocitomas impactará diretamente no prognóstico e planejamento terapêutico a ser oferecido a cães portadores desta doença.

Apesar dos diversos estudos demonstrando a importância do LS, não há ainda um procedimento padrão bem estabelecido para a avaliação do LS na oncologia veterinária. Normalmente, LS são avaliados por citologia ou histopatológico apenas quando estão aumentados e não rotineiramente, levando muitas vezes à um estadiamento incompleto das neoplasias. Além disso, Langenbach et al. (2001) e Williams et al. (2003) reportaram que não deve-se utilizar como parâmetro apenas o aumento do LS à palpação para definir se o linfonodo deve ser aspirado ou biopsiado, uma vez que nem todo LS aumentado é metastático, assim como nem todo LS metastático apresentará aumento de volume.

\footnotetext{
${ }^{10}$ WEISHAAR, K. M.; THAMM, D. H.; WORLEY, D. R.; KAMSTOCK, D. Correlation of nodal mast cells with clinical outcome in dogs with mast cell tumour and a proposed classification system for the evaluation of node metastasis. Journal of Comparative Pathology. (Aceito para publicação em 2014).
} 


\subsubsection{Avaliação do linfonodo sentinela}

\subsubsection{Morfologia do linfonodo}

O linfonodo é constituído por uma região externa, o córtex, rico em células, e uma região interna, a medula, que é contínua com o hilo. Circundando o linfonodo, existe uma cápsula de tecido conjuntivo, a partir da qual trabéculas estendem-se para dentro do parênquima do linfonodo. Os vasos linfáticos aferentes penetram na cápsula e abrem-se no seio subcapsular, o qual percorre todo o linfonodo imediatamente abaixo da cápsula. No seio subcapsular, originam-se os seios peritrabeculares, que penetram no córtex e continuam na região da medula, como seios medulares ramificados, envoltos pelos cordões medulares e que convergem para o hilo, na concavidade do linfonodo. A linfa flui do hilo para dentro de um ou mais vasos linfáticos eferentes, que por sua vez drenam para linfonodos mais próximos. O linfonodo pode ser dividido em quatro regiões: córtex superficial, córtex profundo (ou paracórtex), medula e os seios, com diferentes atividades imunológicas em cada uma delas, contendo principalmente linfócitos $B$, linfócitos $T$, plasmócitos e macrófagos, respectivamente. A região do córtex superficial é onde estão os folículos linfoides, que contém um centro germinativo e uma zona do manto. $O$ centro germinativo contém principalmente linfócitos B em proliferação (linfoblastos), células dendríticas foliculares residentes, células dendríticas foliculares migratórias, macrófagos e células reticulares de sustentação. A zona do manto é constituída por linfócitos B maduros em repouso. Além das células supra citadas, outro tipo de célula que pode eventualmente ser encontrada no linfonodo é o mastócito, principalmente na região dos cordões medulares (SAMUELSON, 2007; VALK; MEIJER, 2007; YOUNG et al., 2007; KIERSZENBAUM, 2008). 


\subsubsection{Biologia da metástase linfática}

A metástase num LS indica o início da disseminação de uma neoplasia pela via linfática. Neoplasias possuem a capacidade de induzir a formação de novos vasos sanguíneos, a partir de vasos pré-existentes, num processo denominado angiogênese, visando obter oxigênio e nutrientes para o seu crescimento e sobrevivência. Estes vasos neoformados exercem um importante papel, promovendo a metástase da neoplasia para órgãos a distância, favorecendo um pior prognóstico ao paciente. O mecanismo da angiogênese tumoral tem sido amplamente estudado, devido sua importância clínica e biológica, entretanto não se sabia se os vasos linfáticos mantinham-se quiescentes nas neoplasias, ou se eles também eram capazes de promover a metástase linfática (ALITALO et al., 2005; HIRAKAWA, 2009). Em 2001, identificou-se o fenômeno de linfangiogênese associada à neoplasia, através da identificação de marcadores específicos de vasos linfáticos e fatores de crescimento linfangiogênicos. (KARPANEN et al., 2001; MANDRIOTA et al., 2001; SKOBE et al., 2001; STACKER et al., 2001). Os principais marcadores de vasos linfáticos descritos são o Prox1, T1a/podoplanina, LYVE1 (receptor endotelial de vaso linfático), FLT4 (fms-like tirosina quinase 4) e VEGFR3 (receptor 3 do fator de crescimento endotelial vascular). Estes marcadores exercem um papel fundamental no desenvolvimento de vasos linfáticos em situações fisiológicas e patológicas (BANERJI et al., 1999; WIGLE; OLIVER, 1999; SHIBUYA, 2010). Hirakawa (2009) reportou que a linfangiogênese tumoral promove ativamente um aumento da drenagem e da metástase para o LS. Segundo este autor, modelos experimentais de carcinogênese demonstraram que a neoplasia primária induz a linfangiogênese também nos focos de metástase, como no LS, contribuindo para a metástase para outros linfonodos e órgãos a distância. A linfangiogênese no LS já foi identificada em diversas neoplasias humanas, como por exemplo no melanoma. Observou-se que os focos metastáticos no LS estavam próximos aos vasos linfáticos e não aos vasos sanguíneos (DADRAS et al., 2005). Similarmente, Van den Eynden et al. (2007) relataram que a linfangiogênese em LS de mulheres portadoras de carcinoma mamário inflamatório induziu metástase em linfonodos não-sentinelas distantes. Hirakawa et al. $(2005,2007)$ demonstraram que a neoplasia primária induz o crescimento de novos vasos linfáticos no LS antes que a metástase ocorra, ou 
seja, a neoplasia primária é capaz de modificar um futuro foco metastático para facilitar a sua implantação, corroborando a "teoria da semente e do solo" proposta em 1889 por Stephan Paget. Desta forma, linfonodos sentinelas podem servir não apenas como indicadores iniciais de metástase, mas também como mediadores da metástase linfática. Tobler e Detmar (2006) em seu estudo, demonstraram que além dos fatores linfangiogênicos VEGF-C (fator $C$ de crescimento endotelial vascular) e VEGF-D (fator $D$ de crescimento endotelial vascular) promoverem o crescimento de vasos linfáticos associados a neoplasias em modelos experimentais, o VEGF-A (fator A de crescimento endotelial vascular) também promove a linfangiogênese, favorecendo a disseminação metastática pela via linfática. A superexpressão de VEGF-A em neoplasias primárias induziu a linfangiogênese no LS antes da metástase ocorrer para o mesmo, e manteve a atividade linfangiogênica no linfonodo após a metástase ter se instalado. Estes autores relataram também um aumento da linfangiogênese em melanomas humanos que metastatizaram, concluindo que o grau de linfangiogênese tumoral pode ser considerado um fator preditivo para metástase em linfonodo e para sobrevida global.

Na veterinária, há poucos estudos sobre a linfangiogênese tumoral, sendo a maioria em neoplasias mamárias em cadelas. Qiu et al. (2008) observaram que o aumento na expressão de VEGF-C em neoplasias mamárias malignas em cadelas correlacionou-se à um maior índice de metástase linfática. Sleeckx et al. (2013) testaram marcadores de vasos linfáticos humanos em cães e concluíram que o Prox1 possui imunorreatividade com o tecido canino. Posteriormente, estes mesmos autores reportaram um aumento da proliferação de células endoteliais linfáticas na região peritumoral de cadelas portadoras de neoplasias mamárias (SLEECKX et al., 2014).

\subsubsection{Métodos de avaliação do LS}

Diversos métodos de avaliação do linfonodo sentinela são descritos na literatura, dentre eles a palpação de linfonodos periféricos, avaliação através de exames de imagem, como ultrassonografia, radiografia, tomografia computadorizada, ressonância magnética, tomografia por emissão de pósitrons 
acoplada a tomografia computadorizada (PET-CT), além da avaliação citomorfológica do linfonodo, por citologia, histologia e imunoistoquímica (GILSON, 1995; PURDIE, 2007; KRICK et al., 2009; PATSIKAS et al., 2010; MURAMOTO et al., 2011; POKORNY et al., 2012).

A palpação de um LS periférico é realizada durante o exame físico, e a partir desta, pode-se avaliar o tamanho, consistência e mobilidade do linfonodo. No entanto, é um método insuficiente e de baixa acurácia para definir a presença de metástase no LS. Um estudo comparou a sensibilidade e especificidade da palpação, análise citológica e histopatológica de 44 LS de 37 cães e 7 gatos portadores de neoplasias malignas. A sensibilidade e especificidade da palpação foi de 60 e 72\% respectivamente, sendo que a mesma avaliação para a análise citológica dos linfonodos foi de 100 e 96\% respectivamente (LANGENBACH et al., 2001). Corroborando estes resultados, o estudo de Williams e Packer (2003) avaliou 100 cães com melanoma oral. Destes, 53 apresentavam metástase em linfonodos mandibulares confirmada por citologia ou histopatológico, sendo que $70 \%$ exibiam aumento dos linfonodos e $30 \%$ exibiam linfonodos em seu tamanho normal. Dos 47 cães que não apresentavam metástase em linfonodo regional, 49\% exibia aumento de volume do linfonodo por hiperplasia reacional. $O$ estudo concluiu que dos 40 animais que apresentavam linfonodos normais à palpação, 40\% tinha evidência de doença micrometastática, sendo que a sensibilidade e especificidade da palpação foram de 70 e 51\%, respectivamente. Baginski et al. (2014) obteve resultados semelhantes em seu estudo que avaliou a presença de metástase linfática em cães portadores de mastocitoma de grau 2. Dos 55 cães avaliados, 61,1\% exibiam aumento de linfonodo regional, sendo que a sensibilidade e especificidade da palpação foi de apenas $71 \%$ e $54 \%$, respectivamente.

O exame ultrassonográfico é capaz de avaliar o tamanho, contorno, arquitetura, ecotextura, ecogenicidade, presença e distribuição do fluxo vascular em linfonodos internos e periféricos. Um estudo comparou o aspecto ultrassonográfico com o histopatológico de linfonodos inguinais de cadelas portadoras de carcinoma mamário. A taxa de concordância entre os exames foi de $92,5 \%$, demonstrando uma sensibilidade de $94 \%$ e especificidade de $92 \%$ da ultrassonografia na detecção de metástase em linfonodos. As principais características ultrassonográficas num linfonodo metastático são: contorno irregular, formato arredondado, arquitetura desorganizada, ecotextura homogênea ou heterogêna, ecogenicidade diminuída e 
vascularização elevada do tipo periférica. Mas os estudos apontam que não há uma característica ultrassonográfica absoluta para categorizar um linfonodo em metastático ou não, e sim uma possível associação de determinadas características com o diagnóstico (NYMAN et al., 2005; MURAMOTO et al., 2011).

Pokorny et al. (2012) avaliaram mastocitomas e seus respectivos LS por ressonância magnética. Os linfonodos metastáticos apresentavam-se maiores em relação ao linfonodo contralateral, além de exibirem um sinal isointenso nas imagens em T1 e sinal hiperintenso nas imagens em T2. Houve moderada a intensa captação do meio de contraste pelos linfonodos, com um padrão de realce heterogêneo.

Apesar dos exames de imagem auxiliarem na identificação de um linfonodo metastático, os métodos mais fidedignos de avaliação consistem naqueles que avaliam a celularidade e a arquitetura do linfonodo (CHAFFIN; THRALL, 2002; WELLE et al., 2008).

Conforme citado anteriormente, a palpação não é um método eficaz na detecção de metástase em linfonodo. Além disso, devem-se considerar outras alterações patológicas que também levam à linfonodomegalia, como a hiperplasia reacional, linfadenite (neutrofílica, eosinofílica, purulenta, piogranulomatosa ou granulomatosa), estimulação imunológica frente a um patógeno e hematopoiese extramedular (COWELL et al., 2003). Mesmo na presença de metástase, o linfonodo pode estar reativo, contendo diversos plasmócitos e linfoblastos, por estimulação do sistema imunológico frente a presença de células neoplásicas, mas também por ulceração, necrose, inflamação ou infecção da neoplasia primária (ZINKL; KEETON, 1981; THRALL, 1987).

A citologia de linfonodo é um método rápido e de baixo custo, que apresenta boa sensibilidade e especificidade na maior parte dos casos. As amostras podem ser coletadas por aspiração com agulha fina ou por imprint após remoção cirúrgica do linfonodo. Deve ser realizada sempre que um LS estiver aumentado, ou mesmo que este não apresente aumento, mas esteja acessível para o exame, a fim de pesquisar a presença de células neoplásicas metastáticas, principalmente tratandose de neoplasias que metastatizam preferencialmente pela via linfática, como as neoplasias epiteliais, melanoma e algumas neoplasias de células redondas, como o mastocitoma (THRALL, 1987; MILLS, 1989; LANGENBACH et al., 2001; COWELL et al., 2003; TUOHY et al., 2009). Considerando-se os mastocitomas cutâneos caninos, os estudos de Marconato et al. (2008) e Krick et al. (2009) propuseram critérios 
citológicos para avaliação de metástases em linfonodos regionais, visando reduzir a subjetividade deste exame, conforme descrito anteriormente.

O histopatológico é o exame de eleição para detectar a presença de metástase em linfonodo (MILLS, 1989; GILSON, 1995). A avaliação histopatológica de linfonodos sentinelas é realizada rotineiramente da oncologia humana, especialmente nos casos de câncer de mama, onde há um protocolo padronizado para a análise destes linfonodos, recomendado pelo Colégio de Patologistas Americanos e pela Sociedade Americana de Oncologia Clínica, em relação ao número de cortes, intervalos de seccionamento, utilização de imunoistoquímica e biologia molecular (LYMAN et al., 2005; VIALLE, 2005; WEAVER, 2010). Na veterinária, apesar de não existir uma padronização, alguns estudos recomendam a realização de múltiplos cortes longitudinais e seriados no linfonodo a ser avaliado, visando aumentar a probabilidade de detecção de células metastáticas. A região subcapsular do linfonodo é o local mais comum de metástase num estágio inicial. A drenagem linfática ocorre via vasos aferentes até o seio subcapsular, carreando células neoplásicas (GADD et al., 1999; HERRING et al., 2002; TUOHY et al., 2009; WORLEY, 2012). No caso dos mastocitomas caninos, não há um critério histopatológico estabelecido que defina a presença de metástase em linfonodo, resultando numa variabilidade entre patologistas na interpretação do diagnóstico. Adicionalmente à coloração hematoxilina-eosina, recomenda-se a aplicação da técnica de histoquímica com o corante azul de toluidina nos cortes histológicos de linfonodos, a fim de facilitar a identificação de mastócitos, através da metacromasia de seus grânulos. No entanto, mastócitos pouco diferenciados podem ser difíceis de serem visualizados no linfonodo, mesmo utilizando o azul de toluidina, pois estas células contem poucos ou nenhum grânulo citoplasmático. Características como presença de diversos mastócitos, ou agregados de mastócitos, muitas vezes com perda da arquitetura do linfonodo, são fáceis de serem identificadas, no entanto a presença de mastócitos isolados no linfonodo, principalmente na ausência de características malignidade nestas células, constitui ainda um desafio para o patologista veterinário em categorizar este linfonodo como metastático ou não. Não é incomum a presença de alguns mastócitos no seio subcapsular de linfonodos sentinelas de mastocitomas (CARSON, 1997; WELLE et al., 2008; BLACKWOOD et al., 2012; WORLEY, 2012). Visando estabelecer um critério de metástase linfática 
em cães portadores de mastocitoma cutâneo, Weishaar et al. (2014) (no prelo) ${ }^{11}$ propuseram um sistema de classificação de metástase, correlacionado os diferentes padrões metastáticos observados à sobrevida, conforme citado anteriormente.

Outro método bastante utilizado na oncologia humana é a avaliação de LS através da técnica de imunoistoquímica (IHQ). A IHQ é amplamente aplicada na pesquisa de metástase de carcinoma mamário em mulheres, utilizando-se a citoqueratina como marcador, sendo um método eficaz na deteç̧ão de micrometástases em linfonodos que foram considerados negativos na avaliação inicial pela hematoxilina-eosina (CSERNI et al., 2006). Egger et al. (2014) referem o uso desta técnica também na identificação de micrometástases em LS de melanoma cutâneo em humanos, utilizando para isto os marcadores S-100, HMB-45, MART-1 e Melan-A.

O uso de técnicas de biologia molecular também foi reportado como auxiliar na detecção de metástase em LS. Gillanders et al. (2004) avaliou o LS de mulheres portadoras de carcinoma mamário por RT-PCR. Ao final do estudo, identificou-se a presença de micrometástase em $33 \%$ dos linfonodos que foram considerados negativos na avaliação histopatológica. Na veterinária, Klopfleisch e Gruber (2009) avaliaram a expressão dos genes BRCA1, BRCA2 e RAD51 por RT-PCR em neoplasias mamárias caninas e seus respectivos linfonodos sentinelas. Ao final do estudo, observou-se uma superexpressão dos genes BCRA2 nas neoplasias mamárias malignas e principalmente do RAD51 nos linfonodos metastáticos.

Krick et al. (2009), em seu estudo que avaliou por citologia linfonodos regionais de cães portadores de mastocitoma cutâneo, sugerem também a análise molecular dos linfonodos a fim de determinar se a presença de mastócitos isolados num LS pode representar já um quadro de metástase em linfonodo.

\footnotetext{
${ }^{11}$ WEISHAAR, K. M.; THAMM, D. H.; WORLEY, D. R.; KAMSTOCK, D. Correlation of nodal mast cells with clinical outcome in dogs with mast cell tumour and a proposed classification system for the evaluation of node metastasis. Journal of Comparative Pathology. (Aceito para publicação em 2014).
} 
MATERIAL E MÉTODOS 


\section{MATERIAL E MÉTODOS}

Este projeto de pesquisa foi aprovado pela "Comissão de Ética no Uso de Animais" da Faculdade de Medicina Veterinária e Zootecnia da Universidade de São Paulo, sob o número de protocolo 2709/2012.

\subsection{SELEÇÃO DOS ANIMAIS}

Foram incluídos no estudo cães atendidos no Serviço de Oncologia do PROVET Instituto Paulista de Especialidades Veterinárias, no período de janeiro/2012 a outubro/2014, com diagnóstico citológico de mastocitoma, não havendo preferência de sexo, idade e raça. Os animais foram selecionados de forma arbitrária e os critérios de inclusão no estudo foram:

a. cães com diagnóstico citológico de mastocitoma, passível de excisão cirúrgica da formação;

b. cães cujo linfonodo sentinela da neoplasia fosse representado por um linfonodo periférico, seja linfonodo mandibular, cervical superficial, axilar, inguinal ou poplíteo;

c. cães com confirmação do diagnóstico da neoplasia e do status do linfonodo sentinela por meio do exame histopatológico após a excisão cirúrgica, que tenham ou não recebido quimioterapia neoadjuvante;

d. cães passíveis de acompanhamento da evolução clínica por no mínimo 12 meses após o procedimento cirúrgico.

\subsection{CRITÉRIOS DE EXCLUSÃO}

Foram excluídos os animais onde a exérese da neoplasia primária não era possível, assim como aqueles cujo linfonodo sentinela possuía localização intraabdominal ou intra-torácica. Mastocitomas classificados como subcutâneos no histopatológico também foram excluídos do estudo. 


\subsection{PROCEDIMENTOS CLÍNICOS E CIRÚRGICOS ESTABELECIDOS}

Os cães com diagnóstico de mastocitoma foram submetidos à avaliação clínica e laboratorial, incluindo anamnese e exame físico, além dos exames complementares para pesquisa de metástase. Em relação à neoplasia primária, foram coletadas informações a respeito da localização, número de formações, consistência, aderência a tecidos adjacentes e presença de ulceração ou necrose. Em relação ao linfonodo sentinela, o mesmo foi avaliado no exame físico por palpação, considerando-se o seu tamanho, consistência e mobilidade. Os exames complementares incluíram hemograma completo e bioquímica sérica, além da radiografia torácica, ultrassonografia abdominal e citologia do linfonodo regional para pesquisa de metástase, desde que o linfonodo fosse acessível para a punção aspirativa por agulha fina. Considerou-se como linfonodo sentinela, o(s) linfonodo(s) mais próximo à neoplasia, baseando-se anatomicamente nos territórios linfáticos descritos no estudo de Suami et al. (2013).

Alguns animais necessitaram de quimioterapia neoadjuvante com o objetivo de redução da neoplasia primária. A quimioterapia adjuvante foi adotada baseandose nos dados obtidos no estadiamento clinico do animal, no diagnóstico histopatológico do mastocitoma e do(s) linfonodo(s) e no diagnóstico imunoistoquímico. O protocolo quimioterápico adotado foi a administração oral de prednisona (2mg/kg/SID/VO por 7 dias; $1.5 \mathrm{mg} / \mathrm{kg} / \mathrm{SID} / \mathrm{VO}$ por $7 \mathrm{dias} ; 1 \mathrm{mg} / \mathrm{kg} / \mathrm{SID} / \mathrm{VO}$ por 7 dias e 0.5mg/kg/SID/VO por mais 7 dias) associado à administração de vimblastina $2 \mathrm{mg} / \mathrm{m}^{2}$ por via intravenosa semanalmente nas 4 primeiras semanas, seguido de aplicações quinzenais por mais 8 semanas, totalizando 8 aplicações de vimblastina. Alguns animais receberam como quimioterapia adjuvante também a lomustina $\left(70 \mathrm{mg} / \mathrm{m}^{2}\right)$ por via oral a cada 3 semanas, masitinib $(12,5 \mathrm{mg} / \mathrm{kg})$ por via oral diariamente ou clorambucil $\left(5 \mathrm{mg} / \mathrm{m}^{2}\right)$ por via oral, em dias alternados. 


\subsubsection{Coleta do material}

Os animais selecionados para este estudo foram submetidos à citologia aspirativa do linfonodo regional previamente ao procedimento cirúrgico. A coleta de citologia dos linfonodos regionais foi realizada utilizando-se agulha 20G, com movimentos em leque, abrangendo vários locais do linfonodo. O conteúdo da agulha foi desprezado em lâmina de vidro com o auxílio de seringa de $10 \mathrm{ml}$, procedendo-se esfregaços do tipo squash para realização da análise citológica. As lâminas de citologia foram secas ao ar livre e posteriormente coradas pelo corante tipo Panótico rápido.

Os animais foram submetidos a intervenção cirúrgica para exérese da neoplasia, com margens amplas em lateralidade, de 2 a $3 \mathrm{~cm}$, incluindo um plano tecidual em profundidade. Linfadenectomia do(s) linfonodo(s) regional(ais) também foi realizada junto ao procedimento cirúrgico. A neoplasia primária, assim como seu(s) respectivo(s) linfonodo(s) regional(ais) foram imersos em solução de formol tamponado a 10\% imediatamente após a excisão cirúrgica e submetidos a avaliação histopatológica para confirmação do diagnóstico, avaliação de margens cirúrgicas e avaliação da presença de metástase em linfonodo.

\subsection{PROCESSAMENTO E GRADUAÇÃO HISTOPATOLÓGICA}

As amostras coletadas foram encaminhadas para o laboratório CVAP (Centro Veterinário de Anatomia Patológica) para a confecção de lâminas para avaliação histopatológica. Secções de $5 \mu \mathrm{m}$ de espessura foram obtidas de cada bloco parafinado da neoplasia primária e de seu(s) respectivo(o) linfonodo(s) sentinela(s) e realizou-se a coloração por Hematoxilina-Eosina.

Os mastocitomas foram graduados segundo as classificações propostas por Patnaik, Ehler e Macewen (1984) em graus 1, 2 ou 3 e por Kiupel et al. (2011), em baixo ou alto grau. Os linfonodos foram classificados quanto à presença ou ausência 
de metástase e quanto ao padrão de metástase, segundo Weishaar et al. (2014) (no prelo) $^{12}$ (Quadro 3).

\subsection{PROCEDIMENTOS HISTOQUÍMICOS}

As lâminas dos linfonodos foram submetidas à coloração pelo azul de toluidina (YOUNG et al., 2006) e pelo aldeído fucsina de Gomori (GOMORI, 1950). Ambas as técnicas evidenciam os grânulos intracitoplasmáticos dos mastócitos, que adquirem uma coloração magenta à avermelhada, facilitando a identificação dos mastócitos nos linfonodos.

\subsection{PROCEDIMENTOS IMUNISTOQUÍMICOS}

O processamento imunoistoquímico foi realizado no Laboratório de Oncologia Experimental e Comparada do Departamento de Patologia da FMVZ/USP e no laboratório VetMol, em Botucatu, São Paulo.

A detecção de c-kit por imunoistoquimica foi realizada nos mastocitomas e nos linfonodos metastáticos. A deteç̧ão de Ki-67 foi realizada apenas nos mastocitomas.

Secções de $5 \mu \mathrm{m}$ de espessura foram obtidas dos blocos parafinados das neoplasias primárias e dos linfonodos e foram aderidas em lâminas silanizadas e colocadas em estufa por 30 minutos a $60^{\circ} \mathrm{C}$. A reidratação foi realizada com 2 banhos em álcool absoluto, por 5 minutos cada banho, seguido por banhos em álcool graduado (95\% e 70\%) e um banho em PBS por 5 minutos.

Posteriormente, os cortes histológicos foram submetidos ao procedimento de recuperação antigênica em solução tampão de ácido cítrico (10 mM, pH 6,0) por 15 minutos, em forno de micro-ondas na potência. Após o resfriamento por 20 minutos no próprio tampão, as amostras foram tratadas para bloqueio de peroxidase

\footnotetext{
${ }^{12}$ WEISHAAR, K. M.; THAMM, D. H.; WORLEY, D. R.; KAMSTOCK, D. Correlation of nodal mast cells with clinical outcome in dogs with mast cell tumour and a proposed classification system for the evaluation of node metastasis. Journal of Comparative Pathology. (Aceito para publicação em 2014).
} 
endógena, por 30 minutos em solução de peróxido de hidrogênio a 5\%, seguindo-se lavagens das lâminas com 5 banhos em PBS de 5 minutos cada. Os cortes foram então incubados em câmera úmida, overnight, a $4^{\circ} \mathrm{C}$, com o anticorpo primários antiKit (Dako, 1:100). Após a incubação, foram realizados três banhos de 5 minutos com PBS e em seguida as lâminas foram incubadas com anticorpo secundário biotinilado kit LSAB+System-HRP ${ }^{13}$ por 30 minutos em temperatura ambiente em câmara úmida. Em seguida, realizaram-se mais três banhos de 5 minutos com PBS. $O$ anticorpo terciário, complexo Estreptoavidina-Biotina kit LSAB+System-HRP5 foi incubado por 30 minutos em câmara úmida em temperatura ambiente. Após a incubação, mais três banhos com PBS foram realizados. A revelação foi realizada através de solução de diaminobenzidina (DAB+Chromogen) ${ }^{5}$ e contra-coradas com Hematoxilina de Harris, por 2 minutos, seguida de lavagem em água corrente. Em seguida realizou-se a desidratação em banhos de álcool graduado (70\%, 95\% e álcool absoluto duas vezes, com 5 minutos cada), seguida pela diafanização com solução de álcool misturado ao xilol e dois banhos de xilol por 10 minutos, seguido da montagem com resina sintética e lamínula.

Para a detecção de Ki-67, inicialmente procedeu-se a desparafinizacao dos cortes histológicos, realizando-se 2 banhos em xilol, por 10 minutos cada e reidratação com 3 banhos em álcool absoluto, por 3 minutos cada, seguidos de mais 2 banhos em álcool graduado (95\% e 85\%), por 3 minutos cada e dois banhos em água deionizada. A recuperação antigênica foi realizada com citrato, pH 6,0, em panela Pascal ${ }^{14}$. Após o resfriamento em temperatura ambiente, as lâminas foram lavadas em água deionizada. O bloqueio da peroxidase endógena foi realizado por 10 minutos em solução de peróxido de hidrogênio $3 \%{ }^{15}$. As lâminas foram lavadas em água deionizada e realizou-se 2 banhos, de 5 minutos cada, em solução Tris

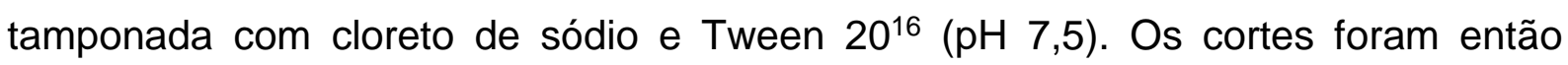
incubados em câmera úmida, overnight, a $4^{\circ} \mathrm{C}$, como o anticorpo primário anti-Ki-67, clone MIB-1, M7240 (Dako, 1:50). Após a incubação, realizou-se mais 2 banhos, de 5 minutos cada, em solução tamponada Tris com cloreto de sódio e Tween $20^{16}(\mathrm{pH}$ $7,5)$ e os cortes foram lavados em água deionizada e posteriormente corados com Hematoxilina de Harris por 2 minutos, seguida de lavagem em água corrente. Em

\footnotetext{
${ }^{13}$ Dako, Carpinteria, CA, USA

${ }^{14}$ Pascal (modelo S2800, DakoCytomation-Carpinteria CA)

${ }^{15} \mathrm{DPH}-125$, Spring Bioscience

${ }^{16}$ TBT-999, Spring Bioscience
} 
seguida realizou-se a desidratação em banhos de álcool graduado $(70 \%, 95 \%$ e álcool absoluto duas vezes, com 5 minutos cada), seguida pela diafanização com solução de álcool misturado ao xilol e dois banhos de xilol por 10 minutos, seguido da montagem com resina sintética e lamínula.

Utilizou-se como controle positivo para o KIT as células interesticiais de Cajal, de intestinos de cães. As células basais da epiderme e as células germinativas dos folículos pilosos, em divisão, foram utilizadas como controle positivo interno para o Ki-67, quando presentes. Na ausência de um controle interno para o Ki-67, utilizouse células de linfoma difuso de grandes células canino como controle positivo. Para controle negativo do KIT e Ki-67, realizou-se a omissão do anticorpo primário, usando o PBS ao invés do anticorpo primário durante o processamento da imunoistoquímica para o c-kit e o TBS para o Ki-67.

\subsubsection{Avaliação da expressão de KIT e Ki-67}

$\mathrm{Na}$ avaliação da expressão de KIT por imunoistoquímica foi utilizada a metodologia descrita por Kiupel et al. (2004), de três padrões distintos de marcação, onde KIT I corresponde a neoplasias com marcação predominante em membrana citoplasmática, com mínima marcação citoplasmática; KIT II neoplasias com marcação citoplasmática intensa focal ou pontilhada e KIT III uma marcação citoplasmática difusa, obscurecendo outras características citoplasmáticas. Cada mastocitoma foi classificado baseando-se na avaliação do padrão mais alto, presente em pelo menos $10 \%$ das células neoplásicas.

A avaliação dos índices de proliferação celular pelo Ki-67 foi realizada através da identificação ao microscópio das áreas com maior marcação (hot spot) em objetiva de 10 aumentos e a partir da identificação destas áreas, as células positivas foram contadas com o auxílio de um retículo de $1 \mathrm{~cm}^{2}$ em objetiva de 40 aumentos, em 5 campos sequenciais (WEBSTER et al., 2007). 


\subsection{EVOLUÇÃO DOS CASOS CLÍNICOS}

Os animais foram acompanhados por um período mínimo de 6 meses após a cirurgia. Realizaram-se radiografias torácicas em 3 projeções e ultrassonografia abdominal a cada 2 meses no primeiro ano e posteriormente a cada 6 meses, para pesquisa de metástase. Realizou-se também exame físico para pesquisa de recidivas ou novas formações. Caso fosse detectado aumento de algum linfonodo periférico ao exame físico, o mesmo era avaliado por citologia aspirativa. Recomendou-se retorno do animal previamente ao período estabelecido caso o proprietário notasse $\mathrm{o}$ aparecimento de novas lesões.

Neste estudo foi considerado como progressão da doença a ocorrência de recidiva local da neoplasia ou o aparecimento de novo mastocitoma (único ou múltiplos) em local diferente da neoplasia primária, assim como a ocorrência de metástase regional ou à distância, após o procedimento cirúrgico.

\subsection{ANÁLISE ESTATÍSTICA}

As variáveis sexo, idade, raça, localização da neoplasia, tamanho e aspecto clínico da neoplasia, margens cirúrgicas e tratamento adjuvante não foram consideradas neste estudo para as análises estatísticas.

O teste exato de Fisher foi utilizado para determinar se as variáveis analisadas associaram-se à presença de metástase em linfonodo. Os riscos relativos (Hazard Ratio - HR) foram calculados pelo método de Mantel-Haenszel e são expressos como coeficientes de $95 \%$ de confiança.

As curvas de eventos ao longo do tempo foram construídas segundo método de Kaplan-Meier e comparados com o teste log-rank. As variáveis significantes nos testes de log-rank foram utilizadas no ajuste do modelo de Regressão de Cox múltiplo.

Utiizou-se o software GraphPad Prism 6 para as curvas de Kaplan-Meirer, teste log-rank e cálculo do risco relativo (HR). Para os testes exatos de Fisher e os modelos de Regressão de Cox utilizou-se o software IBM SPSS 20. 
O valor de $p<0.05$ foi considerado estatisticamente significante. 
RESULTADOS 


\section{RESULTADOS}

\subsection{ESTUDO CLÍNICO}

Foram incluídos neste estudo 57 cães com diagnóstico de mastocitoma, sendo 22 machos $(38,60 \%)$ e 35 fêmeas $(61,40 \%)$. Os cães sem raça definida representaram 22,80\% (13/57) dos animais, seguido por 17,54\% de cães da raça Labrador Retriever (10/57). As demais raças, em ordem decrescente de frequência foram: Golden Retriever (10,52\%, 6/57), Poodle (8,77\%, 5/57), Boxer $(7,01 \%, 4 / 57)$, Pitbull $(7,01 \%, 4 / 57)$, Teckel $(5,26 \%, 3 / 57)$, Schnauzer miniatura $(3,50 \%, 2 / 57)$, Pinscher $(3,50 \%, 2 / 57)$, Pug $(3,50 \%, 2 / 57)$, Beagle $(3,50 \%, 2 / 57)$, seguidos por um representante das raças Chow-Chow, Cocker Spaniel, Shih-tzu e Bernesse Mountain Dog $(1,75 \%, 1 / 57)$. A idade mediana dos animais foi de 9 anos, variando entre 3 e 14 anos de idade. Os dados estão sumarizados na tabela 1.

A maioria dos animais possuía uma única formação $(44 / 57,77,20 \%)$ e 13 animais possuíam duas ou mais formações (22,80\%). Dos 57 animais, foram extraídos 71 mastocitomas e 81 linfonodos. As localizações mais comuns dos mastocitomas foram os membros pélvicos, compreendendo 24 das 71 formações (33,80\%), seguido pela região inguinal $(15 / 71,21,12 \%)$, membros torácicos $(11 / 71$, $15,49 \%)$, região torácica $(9 / 71,12,67 \%)$, região cervical $(4 / 71,5,63 \%)$, cabeça e tronco com três formações cada $(4,22 \%)$ e região abdominal $(2 / 71,2,81 \%)$. O tamanho médio das formações foi de $2,14 \mathrm{~cm}$ de diâmetro, variando de 0,5 a $8 \mathrm{~cm}$. Apenas nove mastocitomas apresentavam ulceração (12,37\%). A consistência das formações variou de firme $(19 / 71,26,76 \%)$ a macia $(52 / 71,73,24 \%)$. Em relação à aderência a tecidos subjacentes, apenas três $(4,22 \%)$ mastocitomas apresentavamse aderidos, enquanto que 68 (95,77\%) não apresentavam aderência. Em relação as margens cirúrgicas, 25 animais $(43,85 \%, 25 / 57)$ apresentaram margens comprometidas após o procedimento cirúrgico. Dos linfonodos regionais excisados, 28 correspondiam aos linfonodos inguinais $(34,56 \%, 28 / 81), 22$ aos linfonodos poplíteos $(27,16 \%, 22 / 81), 16$ aos linfonodos axilares $(19,75 \%, 16 / 81), 12$ aos linfonodos cervicais superficiais $(14,81 \%, 12 / 81)$ e 3 aos linfonodos mandibulares $(3,70 \%, 3 / 81)$. 
Quadro 4 -Características clínicas dos pacientes

\begin{tabular}{|c|c|c|}
\hline Idade (anos) & & 9 anos (3-14) \\
\hline Mediana & & \\
\hline Sexo & & \\
\hline & Machos & 32 \\
\hline & Fêmeas & 35 \\
\hline Raça & & \\
\hline & Sem raça definida & 13 \\
\hline & Labrador Retriever & 10 \\
\hline & Golden Retriever & 6 \\
\hline & Poodle & 5 \\
\hline & Boxer & 4 \\
\hline & Pitbull & 4 \\
\hline & Teckel & 3 \\
\hline & Schnauzer & 2 \\
\hline & miniatura & \\
\hline & Pinscher & 2 \\
\hline & Pug & 2 \\
\hline & Beagle & 2 \\
\hline & Chow-Chow & 1 \\
\hline & Cocker Spaniel & 1 \\
\hline & Shih-tzu & 1 \\
\hline & Bernesse Mountain & 1 \\
\hline & Dog & \\
\hline
\end{tabular}

5.2 CLASSIFICAÇÃO HISTOPATOLÓGICA DOS MASTOCITOMAS

Considerando-se a classificação histopatológica de Patnaik, 3,50\% dos animais apresentaram mastocitoma de grau 1 (2/57), 82,45\% mastocitoma de grau 2 $(47 / 57)$ e $14,05 \%$ mastocitoma de grau 3 (8/57). A diferença na frequência de 
animais por grupo foi estatisticamente significante $(p<0.001)$, sendo maior a frequência de animais com grau 2 em relação aqueles com graus 1 e $3(p<0.01)$. Considerando-se a classificação de Kiupel, 87,71\% (50/57) dos animais apresentaram mastocitoma de baixo grau e $12,29 \%$ (7/57) mastocitoma de alto grau, com diferença significativa entre os grupos $(p<0.001)$. Considerou-se o grau mais alto da neoplasia naqueles animais que apresentavam dois ou mais mastocitomas. Os dados estão sumarizados no quadro 5.

Baseando-se na graduação de Patnaik, nenhum dos animais com grau 1 desenvolveu metástase para linfonodo regional; 57,44\% (27/47) dos cães com mastocitoma de grau 2 e $87,5 \%$ (7/8) dos cães com mastocitoma de grau 3 desenvolveram metástase em linfonodo regional. De acordo com a classificação de Kiupel, 54\% (50/57) dos animais com mastocitoma de baixo grau e 100\% (7/7) daqueles com mastocitoma de alto grau apresentaram metástase em linfonodo regional. Conforme a análise estatística pelo teste exato de Fisher, não houve associação entre a presença de metástase em linfonodo e a graduação histológica de Patnaik $(p=0.1361$; OR $95 \% \mathrm{Cl}=0.02193-1.696)$ e Kiupel $(p=0.8415)$. 
Quadro 5 - Distribuição dos dados das neoplasias, linfonodos e evolução clínica dos animais avaliados no estudo

\begin{tabular}{|c|c|c|c|c|c|c|c|c|c|c|c|c|}
\hline Animal & Localização tumor & $\begin{array}{c}\text { Grau HPT Patnaik/ } \\
\text { Kiupel }\end{array}$ & $\begin{array}{c}\text { C-kit } \\
\text { mastocitoma }\end{array}$ & Ki-67 & LN excisado & Status LN & $\begin{array}{c}\text { Classificação } \\
\text { metástase }\end{array}$ & C-kit LN & $\begin{array}{l}\text { Margens } \\
\text { cirúrgicas }\end{array}$ & QT & Progressão da doença & Óbito (causa) \\
\hline 1 & MP & 1/baixo & & 6 & popliteo & NÃO & NR & $\mathrm{NR}$ & L & Não & Não & Outra causa \\
\hline 2 & abdômen & 2/baixo & 1 & 15 & inguinal & METÁSTASE & HN2 & II & L & VP & Não & Não \\
\hline 3 & MT & 2/baixo & 1 & SM & cerv. Sup. & NÃO & NR & NR & c & VP & Não & Não \\
\hline 4 & ING & 3/alto & II & $>23$ & inguinal & METÁSTASE & HN1 & III & c & VP, LOM, CLOR & Recidiva & Mastocitoma \\
\hline 5 & MP (2) & 2(2) /baixo (2) & 1(2) & $>23(2)$ & popliteo (2) & NÃO & NR & NR & L & VP & Não & Não \\
\hline 6 & ING & 2/baixo & 11 & $>23$ & inguinal & METÁSTASE & HN2 & 1 & c & Não & Recidiva & Mastocitoma \\
\hline 7 & ING & 3/alto & II & $>23$ & inguinal & METÁSTASE & HN2 & ॥ & c & VP & Recidiva & Mastocitoma \\
\hline 8 & MP & 2/baixo & II & 7 & popliteo & NÃO & $\mathrm{NR}$ & NR & L & Não & Não & Não \\
\hline 9 & cervical & 2/baixo & III & 13 & mandibular, cerv. Sup. & NÃO & NR & $\mathrm{NR}$ & L & Não & Não & Não \\
\hline 10 & tórax (1), ING (1) & 2 (2) /baixo (2) & 1(2) & $16(2)$ & inguinal, axilar & NÃO & NR & NR & L & Prednisona & Novo mastocitoma & Não \\
\hline 11 & tronco & 2/baixo & II & 6 & inguinal & NÃO & $\mathrm{NR}$ & NR & L & VP & Não & Não \\
\hline 12 & ING & 2/baixo & 1 & SM & inguinal (2) & METÁSTASE & HN2, HN3 & $\mathrm{I}, \mathrm{II}$ & L & VP & Não & Não \\
\hline 13 & ING & 2/baixo & $i$ & 7 & inguinal (2) & NÃO & NR & $\mathrm{NR}$ & L & vp & Não & Não \\
\hline 14 & MP (2) & 2 (2) /baixo (2) & I(2) & $15(2)$ & inguinal (2) & METÁSTASE & HNO, HN1 & I, NR & L & vp & Não & Não \\
\hline 15 & tórax & 2/baixo & 1 & SM & axilar & METÁSTASE & HN2 & $\frac{1}{10,1 n}$ & L & $\mathrm{VP}$ & Não & Não \\
\hline 16 & MP & 2/baixo & 1 & SM & poplíteo & NÃO & NR & NR & $\mathrm{L}$ & VP, LOM & Recidiva e novo mastocitoma & Mastocitoma \\
\hline 17 & ING & 2/baixo & II & 4 & inguinal & NÃO & NR & $\mathrm{NR}$ & L & Não & Não & Não \\
\hline 18 & MT & 3/alto & III & $>23$ & axilar & METÁSTASE & HN3 (2) & II (2) & L & VP, LOM & Recidiva & Mastocitoma \\
\hline 19 & MP & 2/baixo & 1 & SM & popliteo & NÃO & NR & $\mathrm{NR}$ & L & Não & Não & Não \\
\hline 20 & ING (3) & 3(3) /baixo (3) & IIII (3) & $>23$ & inguinal & NÃO & NR & $\mathrm{NR}$ & c & VP, LOM & Recidiva & Mastocitoma \\
\hline 21 & tórax & 2/baixo & 1 & $>23$ & axilar & METÁSTASE & HN3 & 1 & $\mathrm{~L}$ & VP & Não & Não \\
\hline 22 & cabeça & 3/alto & II & $>23$ & mandibular & METÁSTASE & HN3 & II & c & VP, LOM & Recidiva & Mastocitoma \\
\hline 23 & cervical & 2/baixo & 1 & 8 & cerv. Sup. & NÃO & NR & NR & L & $\mathrm{VP}$ & Não & Não \\
\hline 24 & MT & 2/baixo & 1 & $>23$ & axilar & NÃO & NR & NR & L & Não & Recidiva & Mastocitoma \\
\hline 25 & MP & 2/baixo & 1 & SM & popliteo & NÃO & $\mathrm{NR}$ & NR & L & Não & Não & Não \\
\hline 26 & MP & 2/baixo & 1 & SM & popliteo & NÃO & NR & $\mathrm{NR}$ & c & VP & Não & Não \\
\hline 27 & MT & 2/baixo & 1 & 7 & cerv. Sup. & NÃO & $\mathrm{NR}$ & $\mathrm{NR}$ & L & Não & Não & Outra causa \\
\hline 28 & tronco (1), ING (1) & 2/baixo & II & SM & inguinal & NÃO & $\mathrm{NR}$ & $\mathrm{NR}$ & c & VP & Não & Não \\
\hline 29 & MP & 2/baixo & 1 & 13 & inguinal, popliteo & NÃo & NR & $\mathrm{NR}$ & c & $\mathrm{VP}$ & Não & Não \\
\hline 30 & abdômen (1), tórax (1) & 2(2)/baixo (2) & I, III & $15(2)$ & axilar, inguinal (2) & METÁSTASE & HN1, HN2 (2) & $11(3)$ & c & VP, LOM, CLOR & Novo mastocitoma & Não \\
\hline 31 & MT (1), CERVICAL (1) & 2 (2) /baixo (2) & 1(2) & $14(2)$ & axilar, cerv. Sup. & METÁSTASE & HN1, HN2 & $\mathrm{I}, \mathrm{SM}$ & c & VP & Novo mastocitoma & Não \\
\hline 32 & tórax & 2/baixo & 1 & 10 & axilar & METÁSTASE & HN2 & II & $\mathrm{L}$ & VP & Não & Não \\
\hline 33 & ING & 2/baixo & $\|$ & $>23$ & inguinal & METÁSTASE & HN2 & II & L & VP, LOM, IMAT & Novo mastocitoma & Não \\
\hline 34 & MP (1), MT (1) & 2 (2) /baixo (2) & 1(2) & $3(2)$ & politeo, cerv. Sup. & NÃO & $\mathrm{NR}$ & NR & L & VP & Novo mastocitoma & Não \\
\hline 35 & cabeça & 2/baixo & 1 & $>23$ & mandibular & METÁSTASE & HN2 & 1 & L & VP & Não & Não \\
\hline 36 & $\mathrm{MP}$ & 2/baixo & i & $>23$ & inguinal, popliteo & METÁSTASE & $\mathrm{HN} 2, \mathrm{HN} 1$ & I(2) & L & VP & Novo mastocitoma & Não \\
\hline 37 & MT & 2/baixo & II (2) & $>23(2)$ & cerv. Sup. & METÁSTASE & HN2 & SM & c & VP, LOM, IMAT & Novo mastocitoma & Não \\
\hline 38 & $\operatorname{MP}(1), \operatorname{MT}(1)$ & 2 (2) /baixo (2) & & 5,13 & axilar, poplíteo & METÁSTASE & $\mathrm{HN} 3, \mathrm{NR}$ & $\mathrm{I}, \mathrm{NR}$ & c & VP & Não & Não \\
\hline 39 & tórax & 2/baixo & 1 & $>23$ & axilar & METÁSTASE & HN3 & II & c & VP, LOM & Recidiva e novo mastocitoma & Mastocitoma \\
\hline 40 & tórax (2) & 2 (2) /baixo (2) & I, III & $16,>23$ & axilar (2) & METÁSTASE & HN2 (2) & $\| 1(2)$ & c & VP & Não & Não \\
\hline 41 & tórax & 2/baixo & 1 & SM & axilar (2) & NÃO & NR & NR & L & Não & Não & Não \\
\hline 42 & MP & 2/baixo & 1 & 16 & inguinal, popliteo & METÁSTASE & HN1(2) & $S M, S M$ & c & Não & Não & Outra causa \\
\hline 43 & MP & 2/baixo & 1 & 16 & inguinal, popliteo & NÃO & $\mathrm{NR}$ & NR & c & Não & Não & Não \\
\hline 44 & ING & 2/baixo & II & 17 & inguinal & METÁSTASE & HN2 & "I & $\mathrm{L}$ & Não & Não & Não \\
\hline 45 & $\mathrm{MP}(1)$, tronco (1) & 2 (2) /baixo (2) & I(2) & 10,22 & inguinal, popliteo & METÁSTASE & HNO, HN2 & I, SM & c & Não & Não & Não \\
\hline 46 & MP & 2/baixo & 1 & 10 & poplíteo & METÁSTASE & HNO & SM & c & VP & Não & Não \\
\hline 47 & $\operatorname{MP}(1)$, cervical $(1)$ & 2 (2) /baixo (2) & I(2) & $>23,8$ & politeo, cerv. Sup. & METÁSTASE & HN1, HN2 (2) & I(3) & c & VP & Não & Não \\
\hline 48 & MP & 2/baixo & NR & NR & poplíteo & METÁSTASE & NR & NR & L & VP & Não & Não \\
\hline 49 & MP & 2/baixo & NR & $\mathrm{NR}$ & popliteo (2) & METÁSTASE & NR & $\mathrm{NR}$ & c & VP & Não & Não \\
\hline 50 & MT & 3/alto & 1 & $>23$ & axilar & METÁSTASE & NR & $\mathrm{NR}$ & c & VP, LOM & Novo mastocitoma & Mastocitoma \\
\hline 51 & ING & 2/baixo & NR & NR & inguinal (2) & METÁSTASE & NR & NR & c & VP & Não & Não \\
\hline 52 & MP & $3 / a \mid$ & NR & NR & popli & METÁSTASE & $\mathrm{NR}$ & $\mathrm{NR}$ & c & VP, CLOR & Não & Não \\
\hline 53 & ING & 3/alto & NR & NR & inguinal & METÁSTASE & $\mathrm{NR}$ & NR & c & VP & Não & Não \\
\hline 54 & MP (2) & 2/baixo & NR & NR & inguinal, popliteo & METÁSTASE & NR & NR & L & $\mathrm{VP}$ & Não & Não \\
\hline 55 & cabeça & 2/baixo & III & $>23$ & cerv. Sup. & METÁSTASE & HN1 & 1 & c & VP, LOM & Recidiva & Mastocitoma \\
\hline 56 & MT & 1/baixo & 1 & 3 & axilar & NÃO & NR & NR & $\mathrm{L}$ & Não & Não & Não \\
\hline
\end{tabular}

$\mathrm{MP}=$ membro pélvico, MT $\mathrm{MT}=$ membro torácico, ING = região inguinal, $\mathrm{HPT}=$ histopatológico, $\mathrm{LN}$ = linfonodo, cerv. Sup = cervical superficial, SM = sem marcação, $\mathrm{NR}$ = não realizado, $\mathrm{L}=\mathrm{Livre}, \mathrm{C}=$ comprometida, $\mathrm{QT}=$ quimioterapia, $\mathrm{VP}=$ vimblastina + prednisona, $\mathrm{LOM}=$ lomustina, $\mathrm{CLOR}=$ clorambucil, IMAT $=$ imatinib 


\subsection{MARCADORES IMUNOISTOQUÍMICOS DOS MASTOCITOMAS}

\subsubsection{Expressão do KIT}

Dentre 57 animais em estudo, foram realizadas análises dos padrões de marcação do c-kit em amostras de 51 animais. Naqueles que possuíam mais de um mastocitoma, considerou-se o maior padrão de expressão. Em $64,70 \%$ dos animais (33/51), verificou-se a expressão do padrão KIT-I nas neoplasias; $23,53 \%$ dos animais (12/51) apresentaram padrão KIT-Il e 11,76\% dos animais (6/51) um padrão KIT-III (Figura 2). Houve diferença na frequência de animais entre os três grupos ( $p$ $<0.01$ ), com um maior número de pacientes apresentando padrão KIT-I em relação aqueles que exibiam padrão KIT-II $(p=0.0378)$ e KIT-III $(p=0.0022)$. Não houve diferença significativa entre o número de animais com padrão KIT-II e KIT-III ( $p$ = 0.3793). A figura 2 ilustra os padrões de imunomarcação do KIT.

Dos 51 animais avaliados, 28 exibiam metástase em linfonodo, sendo que $57.14 \%$ (16/28) apresentavam mastocitomas com padrão KIT-I, 28.57\% (8/28) padrão KIT-II e 14.28\% (4/28) padrão KIT-III. Dos 23 animais que não apresentavam metástase em linfonodo, 73.91\%, 17.39\% e 8.70\% exibiam padrão KIT-I, KIT-II e KIT-III, respectivamente. Não houve associação entre a presença de metástase em linfonodo e o padrão de marcação pelo KIT $(p=0.3340)$. Os dados estão sumarizados no quadro 5 . 
Figura 2 - Fotomicrografias dos padrões de marcação imunoistoquímica do KIT, com contracoloração com hematoxilina
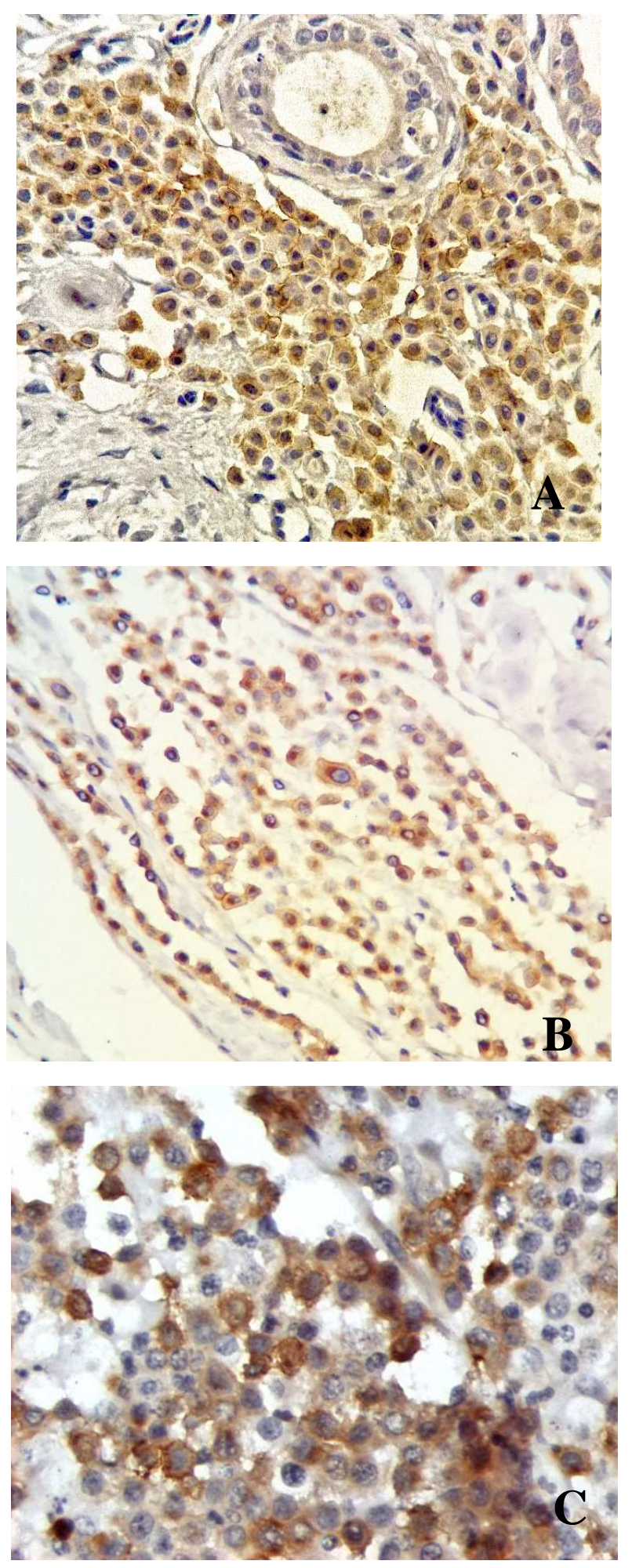

Fonte: (CIRILLO, J. V., 2014)

Legenda: Padrão KIT I (A); Padrão KIT II (B) e Padrão KIT III (C). (Objetiva = 40x). 


\subsubsection{Expressão do Ki-67}

Foram analisadas amostras de 51 animais, no entanto em nove casos não houve marcação pelo Ki-67. Nos animais que tinham mais de uma formação, considerou-se o maior índice do Ki-67. Das 42 amostras analisadas, 54,76\% (23/42) apresentou Ki-67 abaixo de 23 (média de 11,13) e 45,24\% (19/42) apresentou Ki-67 acima de 23 (média de 29,8). Os dados estão sumarizados no quadro 5 . A figura 3 ilustra os padrões de imunomarcação do Ki-67.

Dos 42 animais avaliados, 27 apresentavam metástase em linfonodo. Nestes, $59.25 \%$ (16/27) apresentavam mastocitoma com Ki-67 acima de 23 e 40.75\% (11/27) Ki-67 abaixo de 23. Já dos 15 animais sem metástase em linfonodo, 20\% apresentou mastocitoma com Ki-67 acima de 23 e 80\% exibia neoplasia com Ki-67 abaixo de 23. O valor médio do Ki-67 para os animais que apresentavam metástase em linfonodo foi de 23,5 e 12,2 para aqueles sem metástase em linfonodo. Houve associação significante entre a presença de metástase em linfonodo e o índice do Ki-67 da neoplasia primária $\left(P=0.0232 ; \mathrm{OR}_{95} \mathrm{Cl}=1.324-25.56\right)$, sendo que $\mathrm{Ki}-67$ acima de 23 associou-se com maior prevalência de metástase no linfonodo. 
Figura 3 - Fotomicrografias dos padrões de marcação imunoistoquímica com Ki-67, com contracoloração com hematoxilina
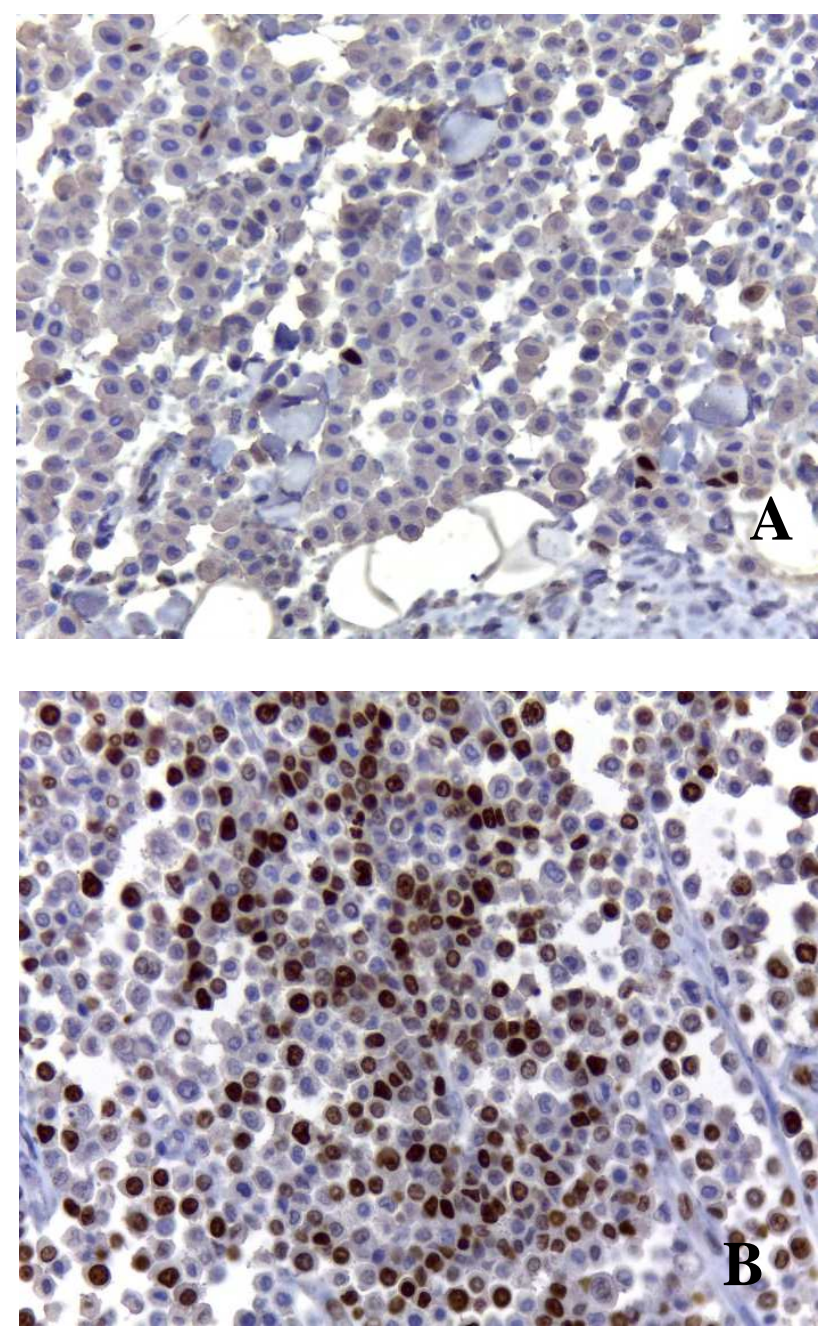

Fonte: (CIRILLO, J. V., 2014)

Legenda: Poucos núcleos marcados pelo Ki-67 (A); acima de 23 núcleos marcados pelo Ki-67 (B). (Objetiva $=40 x$ ).

\subsection{AVALIAÇÃO DOS LINFONODOS}

Dos linfonodos regionais excisados, 28 correspondiam aos linfonodos inguinais $(34,56 \%, 28 / 81), 22$ aos linfonodos poplíteos $(27,16 \%, 22 / 81), 16$ aos linfonodos axilares $(19,75 \%, 16 / 81), 12$ aos linfonodos cervicais superficiais $(14,81 \%, 12 / 81)$ e 3 aos linfonodos mandibulares $(3,70 \%, 3 / 81)$. Os dados estão sumarizados no quadro 5 . 
Foi realizada citologia aspirativa em 46 linfonodos, sendo que em 36 (75\%) o resultado da citologia foi correspondente ao diagnóstico histopatológico; em 6 $(12,5 \%)$ obteve-se resultado falso positivo e em 4 (8,5\%), falso negativo. A sensibilidade e especificidade do exame foram de $86 \%$ e $64 \%$, respectivamente. $O$ valor preditivo positivo do exame foi de $80 \%$ e o valor preditivo negativo foi de $73 \%$.

As avaliações histológicas e histoquímicas evidenciaram a presença de metástase em 59,25\% (48/81) dos linfonodos excisados de 34 animais (34/57, $59,64 \%$ ) (Figuras 4 e 5). Vinte e quatro linfonodos $(29,62 \%, 24 / 81)$ apresentavam-se aumentados à palpação e 57 possuíam tamanho normal $(70,38 \%, 57 / 81)$, sendo $75 \%$ e $52,63 \%$ positivos para metástase, respectivamente. Em relação a consistência dos linfonodos, 20,98\% (17/81) exibiam uma consistência firme e $79,02 \%$ (64/81) consistência normal, sendo $76,47 \%$ e 54,68\% com metástase, respectivamente. Apenas 3 linfonodos (3,70\%) estavam aderidos a tecidos subjacentes enquanto que os 78 linfonodos restantes (96,30\%) não apresentavam aderência e o índice de metástase nestes linfonodos foi de $100 \%$ e $57,69 \%$, respectivamente.

Figura 4 - Fotomicrografia da coloração histoquímica pelo azul de toluidina

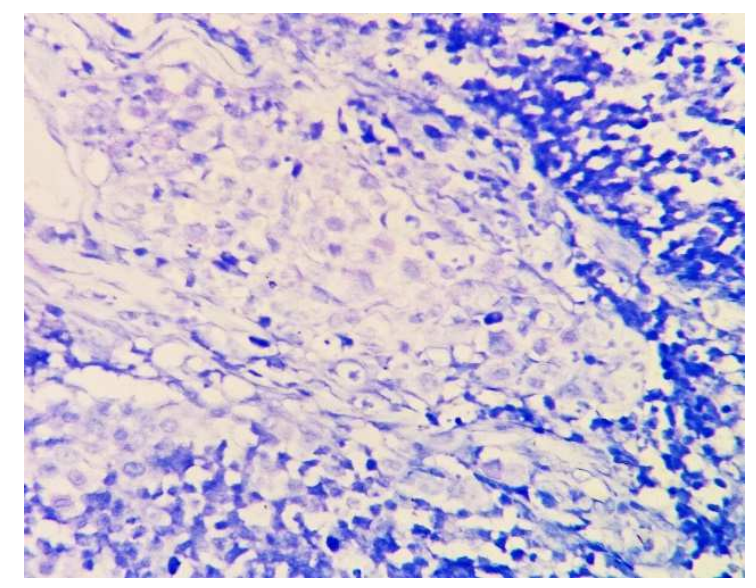

Fonte: (CIRILLO, J. V., 2014)

Legenda: Metástase em linfonodo evidenciada pela técnica de histoquímica com azul de toluidina (Objetiva $=40 x)$. 
Figura 5 - Fotomicrografia da coloração histoquímica pelo aldeído-fucsina de Gomori

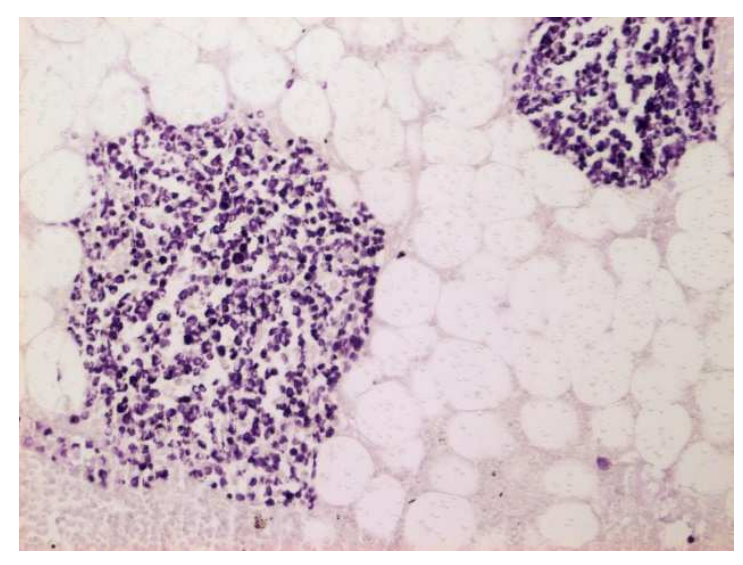

Fonte: (CIRILLO, J. V., 2014)

Legenda: Metástase em linfonodo evidenciada pela técnica de histoquímica com aldeído-fucsina de Gomori. (Objetiva $=20 \mathrm{x})$.

O índice de metástase para linfonodo regional nos animais que apresentavam uma única formação foi de $56,81 \%$ (25/44) e 69,23\% (9/13) naqueles que exibiam duas ou mais formações. De acordo com a análise estatística pelo teste exato de Fisher, não houve associação entre o número de formações e a presença de metástase em linfonodo $(P=0.1897)$.

A classificação do padrão metastático foi realizada em 27 animais. Naqueles animais com mais de um linfonodo metastático, considerou-se o padrão mais alto da classificação. Um caso foi classificado como HN0 (1/27, 3,70\%), 4 como HN1 (4/27, $14,81 \%), 16$ como HN2 (16/27, 59,25\%) e 6 como HN3 (6/27, 22,22\%).

A avaliação da expressão de c-kit foi realizada em 38 linfonodos metastáticos. Seis linfonodos não apresentaram marcação para KIT. 15 linfonodos (15/32, 46,87\%) apresentaram padrão KIT-I; 16 apresentaram padrão KIT-II (16/32, 50\%) e apenas 1 (1/32, 3,13\%) padrão KIT-III (Figuras 6 e 7). Dos 32 linfonodos onde foi possível avaliar a expressão de KIT, 19 (59,37\%) apresentavam o mesmo padrão de marcação da neoplasia primária; 5 (15,62\%) apresentaram um grau menor em relação à neoplasia primária e $8(25,01 \%)$ um grau maior em relação à neoplasia primária. 
Figura 6 - Fotomicrografia da marcação imunoistoquímica do KIT e da coloração histoquímica pelo azul de toluidina em linfonodo
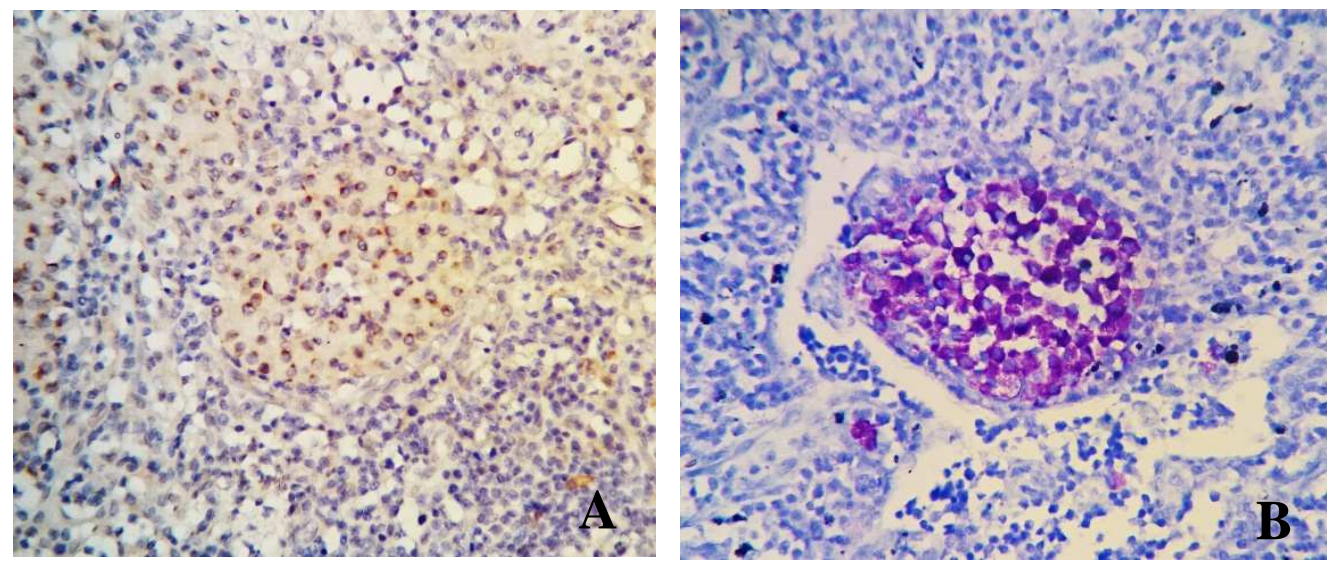

Fonte: (CIRILLO, J. V., 2014)

Legenda: Metástase em linfonodo evidenciada pela imunocarcação do KIT (padrão KIT II) (A). Mesmo campo de metástase em linfonodo evidenciada pela técnica de histoquímica com azul de toluidina (padrão HN2) (B). (Objetiva = 20x).

Figura 7 - Fotomicrografia da marcação imunoistoquímica do KIT e da coloração histoquímica pelo azul de toluidina em linfonodo
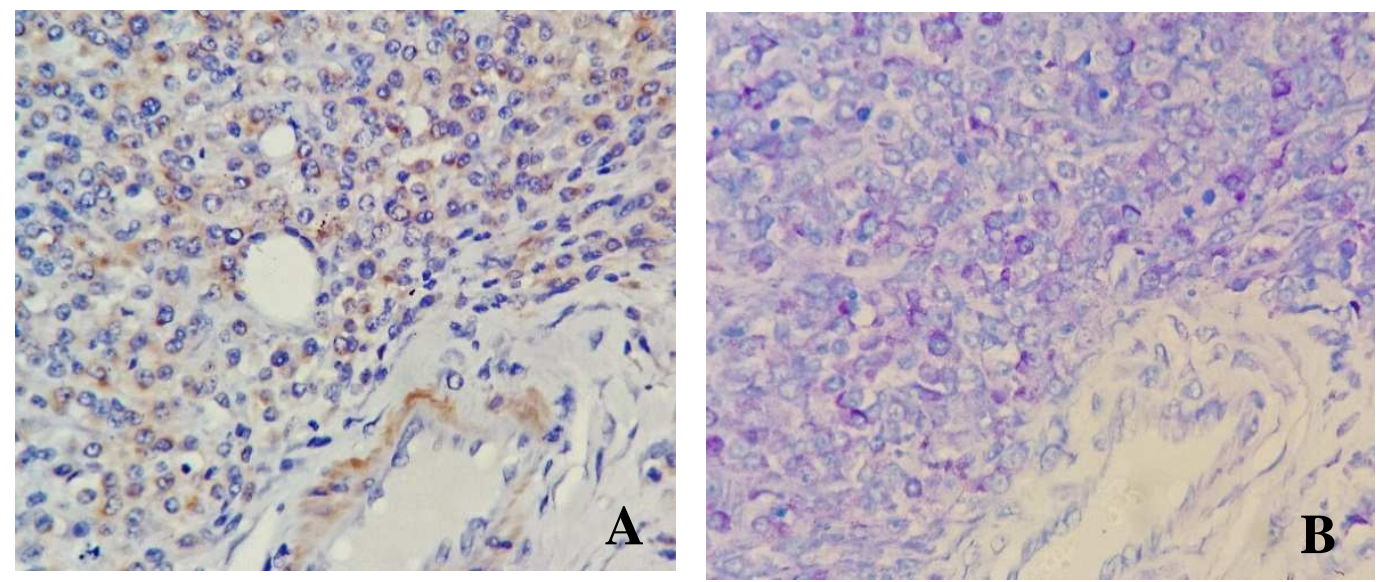

Fonte: (CIRILLO, J. V., 2014)

Legenda: Metástase em linfonodo evidenciada pela imunocarcação do KIT (padrão KIT II) (A). Mesmo campo de metástase em linfonodo evidenciada pela técnica de histoquímica com azul de toluidina (padrão HN3) (B). (Objetiva = 20x).

\subsection{EVOLUÇÃO DOS CASOS CLÍNICOS}

Os pacientes foram acompanhados de julho de 2012 a outubro de 2014 para a obtenção dos dados a respeito da evolução dos casos clínicos. 
Dos 57 animais, em 12 (21,05\%) realizou-se quimioterapia neoadjuvante e em 42 (73,68\%) quimioterapia adjuvante, sendo em 29 animais o protocolo de vimblastina com prednisona; em 7 animais vimblastina e lomustina; em 2 animais vimblastina, lomustina e posteriormente clorambucil; em 2 animais vimblastina, lomustina e posteriormente masitinib, em 1 animal vimblastina com prednisona e posteriormente clorambucil e em um animal, apenas prednisona. Os dados estão sumarizados no quadro 5.

Apenas um animal apresentava metástase à distância (em baço) no momento do diagnóstico. O principal foco de metástase neste estudo foram os linfonodos regionais (34/57), seguido pelo baço (4/57) e fígado (2/57) e dois (2/57) animais apresentaram metástase para baço e fígado ao mesmo tempo.

Dos 57 animais avaliados, 14 (24,56\%) vieram a óbito, sendo 11 (19,29\%, 11/57) relacionados ao mastocitoma e 43 cães ainda encontram-se vivos.

Dos pacientes que vieram a óbito em decorrência da evolução da doença, dez (10/11) apresentavam uma única formação e 1 animal apresentava múltiplos mastocitomas; 72,72\% (8/11) apresentavam metástase em linfonodo regional; cinco cães $(45,45 \%, 5 / 11)$ eram portadores de mastocitoma de grau 2 e seis $(54,55 \%$, $6 / 11)$ de grau 3, pela graduação de Patnaik; seis cães $(54.55 \%$, 6/11) possuíam mastocitoma de baixo grau e cinco $(45,45 \%, 5 / 11)$ de alto grau, pela classificação de Kiupel; quatro cães $(36,36 \%, 4 / 11)$ exibiam mastocitoma com padrão KIT-I, quatro $(36,36 \%, 4 / 11)$ padrão KIT-II e três $(27.28 \%, 3 / 11)$ padrão KIT-III; todos exibiam um valor de Ki-67 acima de 23. Em relação a progressão da doença, 90,90\% (10/11) apresentaram recidiva da neoplasia e 27,27\% (3/11) desenvolveram um novo mastocitoma, num período médio de 85 dias após a cirurgia (variando entre 30 e 152 dias). Dos 8 animais com metástase em linfonodo, classificou-se o padrão de metástase em 7, sendo 2 (28,57\%) padrão HN1, 2 (28,57\%) HN2 e 3 (42,86\%) HN3.

Dos 43 animais que permanecem vivos, trinta e um (31/43, 72,09\%) apresentavam uma única formação e doze (12/43, 27,91\%) exibiam múltiplos mastocitomas; 58,13\% (25/43) dos cães apresentavam metástase em linfonodo regional; um animal (1/43) tinha diagnóstico de mastocitoma de grau 1, 40 (40/43, 93,02\%) de grau 2 e $2(2 / 43,4,65 \%)$ de grau 3, pela graduação de Patnaik; 41 $(41 / 43,95,34 \%)$ apresentavam mastocitoma de baixo grau e dois $(2 / 43,4,66 \%)$ de alto grau, segundo a graduação de Kiupel; vinte e seis (26/43, 60,46\%) exibiam mastocitomas com padrão KIT-I, oito (8/43, 18,60\%) padrão KIT-II e três (3/43, 
6,96\%) padrão KIT-III; vinte (20/43, 46,51\%) apresentaram neoplasia com índice de Ki-67 abaixo de 23 e em oito (8/43, 53,49\%) o valor do Ki-67 foi acima de 23 . Em relação a progressão da doença, nenhum apresentou recidiva local e sete animais $(16,27 \%, 7 / 43)$ desenvolveram novo mastocitoma, num período médio de 148 dias após a cirurgia (variando entre 30 e 244 dias). Dos 25 animais com metástase em linfonodo, classificou-se o padrão de metástase em 20, sendo 1 com padrão HNO (1/20, 5\%), 2 com padrão HN1 (2/20, 10\%), 14 com padrão HN2 (70\%) e 3 padrãoHN3 $(3 / 20,15 \%)$.

Um total de 18 animais $(31,57 \%, 18 / 57)$ apresentaram progressão da doença ( 8 casos de recidiva local, 8 de desenvolvimento de novo mastocitoma e 2 onde ambos os eventos ocorreram). Destes cães, 72,22\% (13/18) apresentavam metástase em linfonodo regional e cinco $(27,78 \%)$ não apresentavam, no momento do diagnóstico. Não houve associação entre a presença de metástase em linfonodo e a progressão da doença ( $p=0.6148 ; \mathrm{OR}=0.03416-4.684)$.

As curvas de Kaplan-Meier mostram que não houve diferença significativa na sobrevida dos animais com e sem metástase em linfonodo regional $(p=0.2992$; HR: 0.5899-5.680) (Figura 8), nem no intervalo livre de doença ( $p=0.3650$; HR: 0.53835.386) (Figura 9). A presença de metástase em linfonodo não apresentou também valor preditivo na análise multivariada de Cox (Tabelas 1 e 3). A sobrevida e 0 intervalo livre de doença não foram alcançados tanto nos animais com metástase, como naqueles sem metástase em linfonodo, devido ao baixo número de eventos (óbito, recidiva ou nova formação). 
Figura 8 - Curva de Kaplan-Meier de análise de sobrevida nos pacientes com e sem metástase em linfonodo

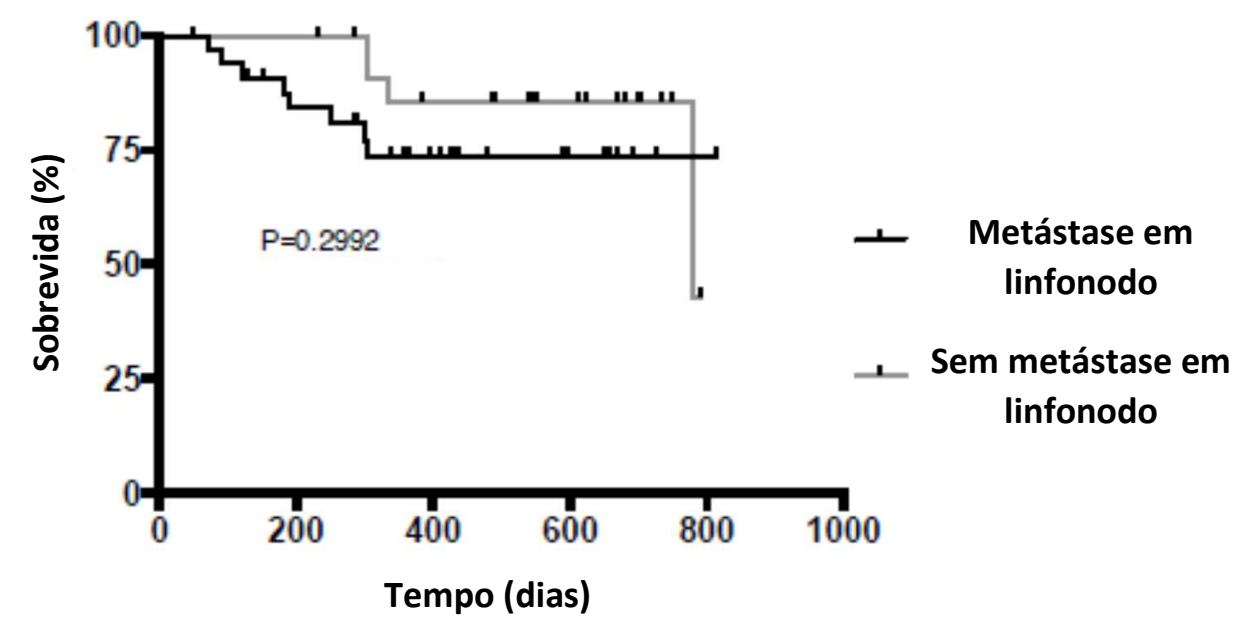

Fonte: (CIRILLO, J. V., 2014)

Legenda: Sem diferença significativa $(p=0.2992 ; H R=0.5899-5.680)$

Figura 9 - Curva de Kaplan-Meier de análise do tempo livre de doença nos pacientes com e sem metástase em linfonodo

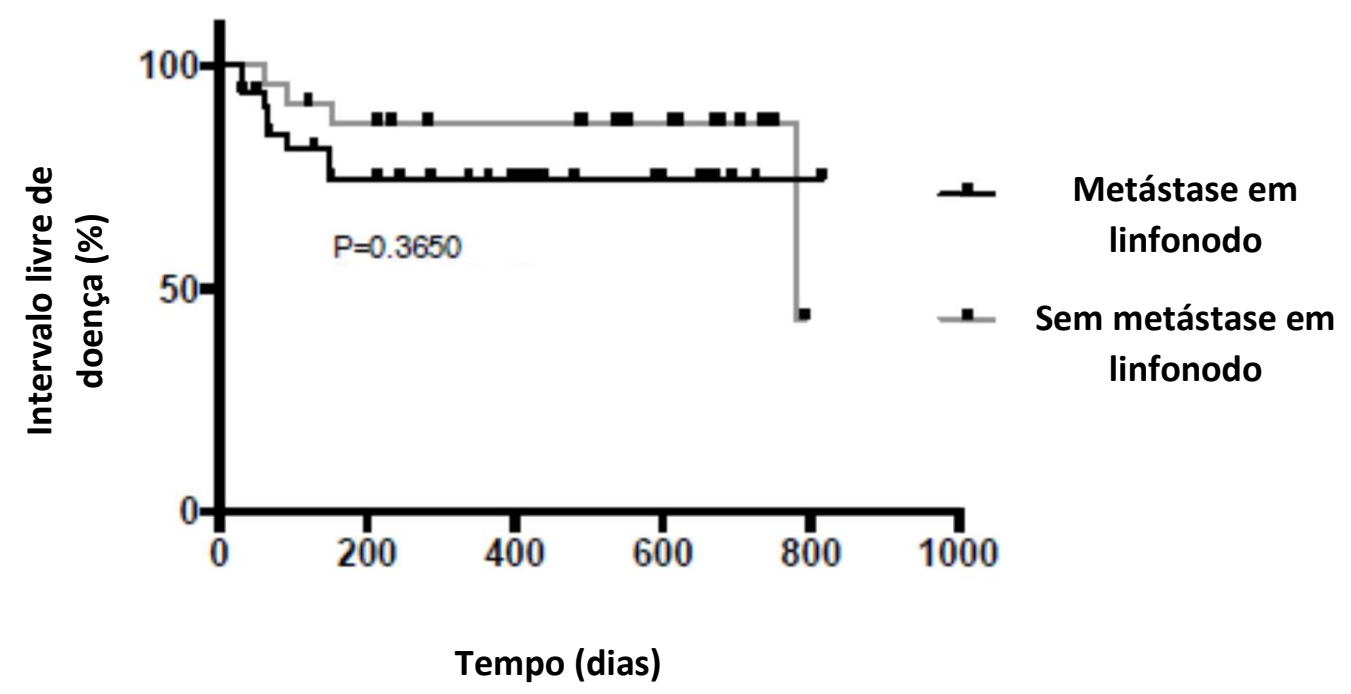

Fonte: (CIRILLO, J. V., 2014)

Legenda: Sem diferença significativa $(p=0.3650 ; H R=0.5383-5.686)$. 
A variável grau histológico (Patnaik e Kiupel) associou-se à sobrevida e ao intervalo livre de doença, independentemente da presença de metástase em linfonodo, conforme demonstrado pelas curvas de Kaplan-Meier. As análises considerando os mastocitomas de grau 1, pela graduação de Patnaik, não foram possíveis devido ao baixo número de animais neste grupo. De acordo com a classificação de Patnaik, observamos menor sobrevida e tempo livre de doença nos animais diagnosticados com mastocitomas de grau 3 (mediana de 190 dias e 120 dias, respectivamente) em relação aqueles com mastocitomas de grau 2 (tempo não alcançado em ambas as análises) ( $\mathrm{p}<0.001$; HR $9.53 \times 10^{-6}-1.55 \times 10^{-3}$ e $\mathrm{p}<<$ $0.001 ; \mathrm{HR}=1.076 \times 10^{-3}-5.452 \times 10^{-2}$, respectivamente) (Figuras 10 e 11). Segundo a graduação de Kiupel, observamos também menor sobrevida e intervalo livre de doença nos cães com mastocitomas de alto grau (mediana de 183 dias e 90 dias, respectivamente) em relação aqueles com neoplasia de baixo grau (tempo não alcançado em ambas as análises) ( $p<<0.001$; HR $1.33 \times 10^{-6}-5.27 \times 10^{-4}$ e $p<<$ $0.001 ; \mathrm{HR}=0.0033175-0.1557$, respectivamente) (Figuras $12 \mathrm{e} 13$ ).

Figura 10 - Curva de Kaplan-Meier de análise de sobrevida segundo a graduação histológica de Patnaik

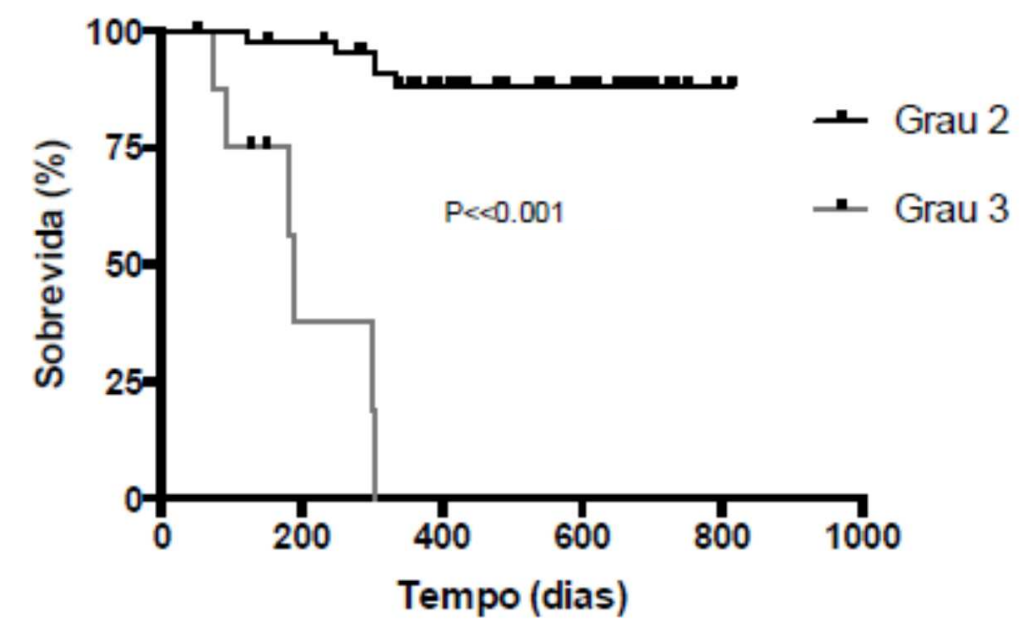

Fonte: (CIRILLO, J. V., 2014)

Legenda: Diferença significativa $\left(p \ll 0.001 ; \mathrm{HR}=9.53 \times 10^{-6}-1.55 \times 10^{-3}\right)$. 
Figura 11 - Curva de Kaplan-Meier de análise do tempo livre de doença segundo a graduação histológica de Patnaik

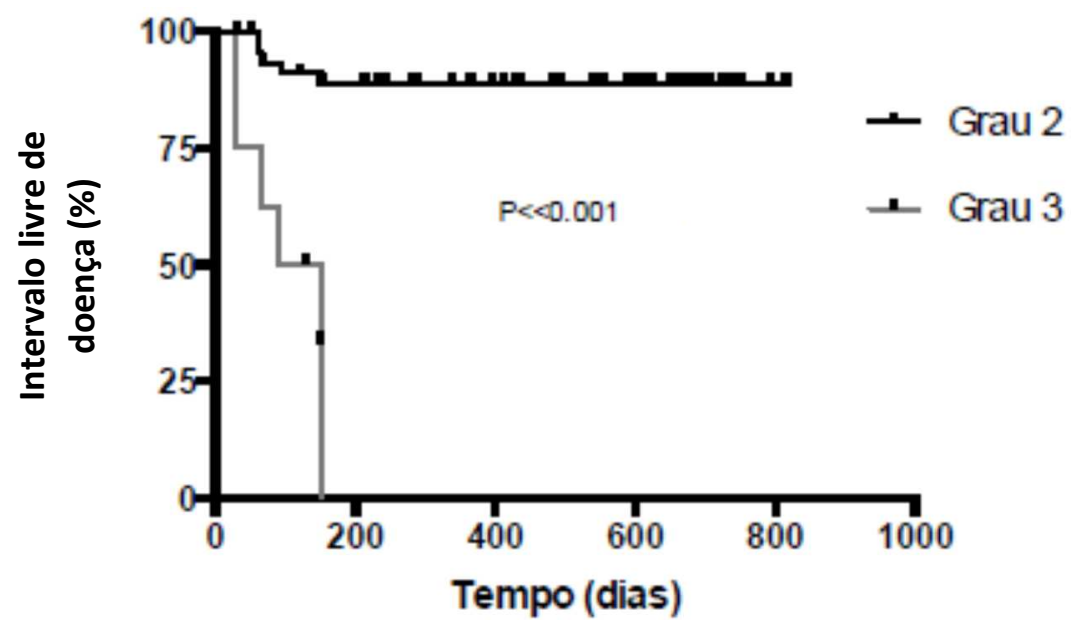

Fonte: (CIRILLO, J. V., 2014)

Legenda: Diferença significativa $\left(p<0.001 ; \mathrm{HR}=1.076 \times 10^{-3}-5.452 \times 10^{-2}\right)$.

Figura 12 - Curva de Kaplan-Meier de análise de intervalo livre de doença segundo a graduação histológica de Kiupel

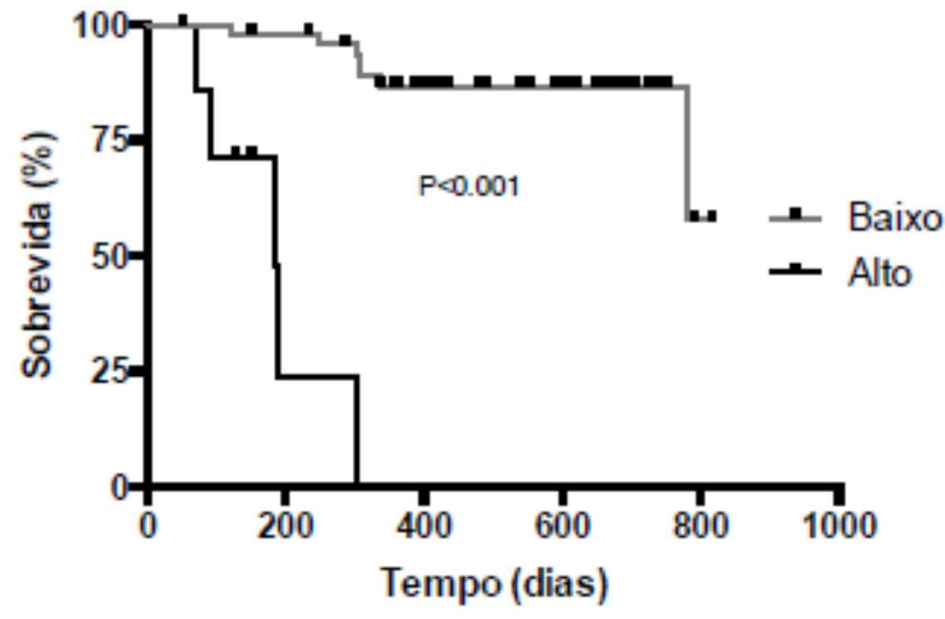

Fonte: (CIRILLO, J. V., 2014)

Legenda: Diferença significativa $\left(p<<0.001 ; \mathrm{HR}=1.33 \times 10^{-6}-5.27 \times 10^{-4}\right)$. 
Figura 13 - Curva de Kaplan-Meier de análise de intervalo livre de doença segundo a graduação histológica de Kiupel

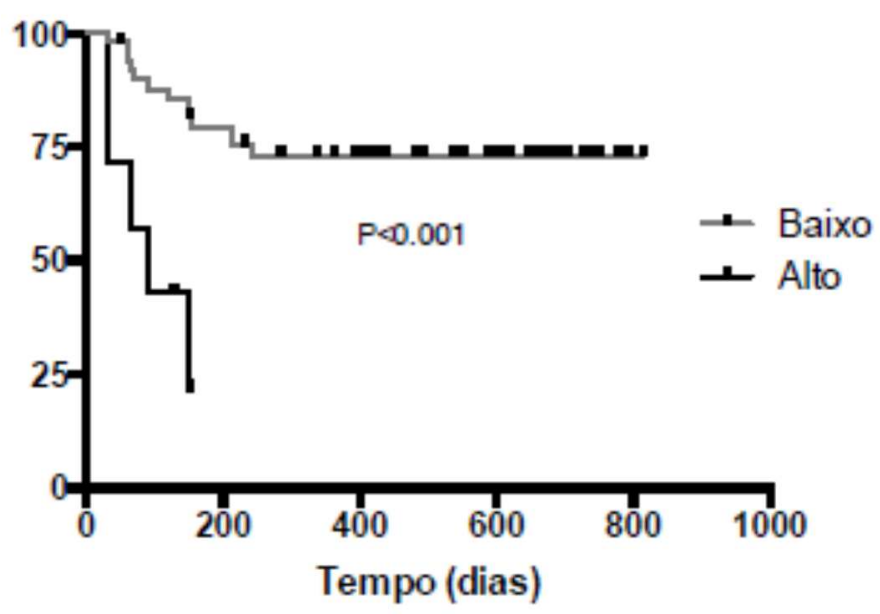

Fonte: (CIRILLO, J. V., 2014)

Legenda: Diferença significativa $(p<<0.001 ; H R=0.0033175-0.1557)$.

De acordo com a análise multivariada pela regressão de Cox observamos que o padrão de marcação do KIT não mostrou efeito na sobrevida (Tabela 1) nem no intervalo livre de doença dos pacientes (Tabela 3).

Já o índice de Ki-67 apresentou efeito estatisticamente significante na sobrevida (Tabela 1) e no intervalo livre de doença (Tabela 3), independente da presença de metástase em linfonodo, com menor sobrevida e tempo livre de doença nos animais que apresentavam Ki-67 acima de 23. Além disso, as variáveis Ki-67 e a graduação histológica de Kiupel, quando associadas, mostraram melhor valor prognóstico (Tabelas 2 e 4). Animais diagnosticados com mastocitoma de alto grau e Ki-67 acima de 23 apresentaram menor sobrevida e tempo livre de doença. 
Tabela 1 - Descrição das variáveis e seus efeitos na sobrevida (Modelo não ajustado)

\begin{tabular}{lcccc}
\hline Variável & Sig. $(\mathrm{P})$ & $\operatorname{Exp}(\beta)$ & \multicolumn{2}{c}{ IC $(95 \%)$ para $\operatorname{Exp}(\beta)$} \\
\cline { 4 - 5 } & & & Inferior & Superior \\
\hline Kiupel & .001 & .034 & .004 & .274 \\
KIT padrão I & .334 & & & \\
KIT padrão II & .399 & .445 & .068 & 2.920 \\
KIT padrão III & .141 & .269 & .047 & 1.544 \\
Ki-67 & .007 & .046 & .005 & .424 \\
Metástase em LN & .458 & 1.386 & .585 & 3.280
\end{tabular}

Sig = significância; $P=$ valor de $p ; \operatorname{Exp}(\beta)=$ exponencial do valor de $\beta ; I C=$ intervalo de confiança Fonte: (CIRILLO, J. V., 2014)

Tabela 2 - Descrição das variáveis graduação histológica de Kiupel e Ki-67 e seus efeitos na sobrevida (Modelo ajustado)

\begin{tabular}{lcccc}
\hline Variável & Sig. $(\mathrm{P})$ & $\operatorname{Exp}(\beta)$ & \multicolumn{2}{c}{ IC (95\%) para $\operatorname{Exp}(\beta)$} \\
\cline { 3 - 5 } & & & Inferior & Superior \\
\hline Kiupel & .001 & .059 & .011 & .326 \\
Ki-67 & .012 & .062 & .007 & .537 \\
\hline
\end{tabular}

Sig = significância; $P=$ valor de $p ; \operatorname{Exp}(\beta)=$ exponencial do valor de $\beta ; I C=$ intervalo de confiança

Fonte: (CIRILLO, J. V., 2014)

Legenda: Graduação histológica de Kiupel associada ao Ki-67 apresentou maior efeito no prognóstico quando comparada à utilização apenas da graduação histológica $(p=0.002)$. 
Tabela 3 - Descrição das variáveis e seus efeitos no intervalo livre de doença (Modelo não ajustado)

\begin{tabular}{|c|c|c|c|c|}
\hline \multirow[t]{2}{*}{ Variável } & \multirow[t]{2}{*}{ Sig. } & \multirow[t]{2}{*}{$\operatorname{Exp}(\beta)$} & \multicolumn{2}{|c|}{ IC $(95 \%)$ para $\operatorname{Exp}(\beta)$} \\
\hline & & & Inferior & Superior \\
\hline Kiupel & .020 & .204 & .054 & .780 \\
\hline KIT padrão I & .843 & & & \\
\hline KIT padrão II & .624 & .713 & .184 & 2.765 \\
\hline KIT padrão III & .588 & .697 & .189 & 2.577 \\
\hline Ki67 & .019 & .209 & .056 & .776 \\
\hline Metástase em LN & .898 & 1.042 & .555 & 1.956 \\
\hline
\end{tabular}

Sig = significância; $P=$ valor de $p ; \operatorname{Exp}(\beta)=$ exponencial do valor de $\beta ; I C=$ intervalo de confiança Fonte: (CIRILLO, J. V., 2014)

Tabela 4 - Descrição das variáveis graduação histológica de Kiupel e Ki-67 e seus efeitos no intervalo livre de doença (Modelo ajustado)

\begin{tabular}{|c|c|c|c|c|}
\hline \multirow[t]{2}{*}{ Variável } & \multirow[t]{2}{*}{ Sig. $(P)$} & \multirow[t]{2}{*}{$\operatorname{Exp}(\beta)$} & \multicolumn{2}{|c|}{ IC $(95 \%)$ para $\operatorname{Exp}(\beta)$} \\
\hline & & & Inferior & Superior \\
\hline Kiupel & .001 & .059 & .011 & .326 \\
\hline Ki-67 & .012 & .062 & .007 & .537 \\
\hline
\end{tabular}

Sig = significância; $P=$ valor de $p ; \operatorname{Exp}(\beta)=$ exponencial do valor de $\beta ; I C=$ intervalo de confiança

Fonte: (CIRILLO, J. V., 2014)

Legenda: Graduação histológica de Kiupel associada ao Ki-67 apresentou maior efeito no prognóstico quando comparada à utilização apenas da graduação histológica $(p=0.005)$. 
DISCUSSÃO 


\section{DISCUSSÃO}

Linfonodo sentinela (LS) é definido como o primeiro linfonodo que recebe a drenagem linfática de um sítio tumoral. Por isso, a presença ou ausência de células neoplásicas num LS é preditiva da disseminação linfática de uma neoplasia e a análise histopatológica do LS refletirá o status da doença no paciente (COCHRAN; OHSIE; BINDER, 2008; GOYAL; MANSEL, 2008). O conceito de mapeamento linfático e identificação do linfonodo sentinela já está bem estabelecido na oncologia humana, principalmente em pacientes com carcinoma mamário e melanoma (MORTON et al., 1992; PURDIE, 2007). No entanto, na medicina veterinária esta prática ainda é pouco utilizada. Normalmente, a avaliação de linfonodo sentinela, se realizada, só ocorre quando o linfonodo encontra-se aumentado à palpação, acarretando no estadiamento incompleto da neoplasia (TUHOY et al., 2009). Dada a importância da avaliação do LS em diversas neoplasias em humanos e em animais, incluindo o mastocitoma cutâneo canino, uma atenção maior deve ser dedicada à esta questão. Por esta razão, este estudo objetivou a análise de linfonodos regionais em cães com diagnostico de mastocitoma, analisando se a presença de metástase associou-se a um pior prognóstico e menor sobrevida nestes pacientes.

Para isto, optou-se primeiramente por realizar análise citológica dos linfonodos, com dois objetivos: avaliar a eficácia deste exame no diagnóstico de metástase e demonstrar a importância da citologia no estadiamento e no tratamento de animais com mastocitoma cutâneo. Posteriormente, realizou-se análise histopatológica e imunoistoquímica das neoplasias e seus respectivos linfonodos sentinelas para a obtenção de dados a respeito do comportamento biológico do mastocitoma, correlacionado-os à presença de metástase em linfonodo. Os resultados obtidos neste estudo visam demonstrar a importância do linfonodo sentinela no mastocitoma cutâneo canino, auxiliando o médico veterinário na decisão pela melhor conduta terapêutica nos pacientes portadores desta neoplasia.

Os animais selecionados para este estudo foram provenientes da casuística do Serviço de Oncologia do Provet, Instituto Paulista de Diagnóstico e Especialidades Veterinárias. A pesquisa foi desenhada de forma retrospectiva e prospectiva, sendo que os pacientes deveriam ter diagnóstico de mastocitoma confirmado por histopatológico, o procedimento cirúrgico deveria incluir a exérese 
do(s) mastocitoma(s) e seu(s) respectivo(s) linfonodo(s) regional(ais) e os pacientes deveriam ser acompanhados por um período mínimo de 12 meses para a análise de sobrevida. Não foi possível obter os blocos parafinados dos mastocitomas e linfonodos de todos os animais que fizeram parte do estudo retrospectivo, assim como em alguns casos, houve falha na análise imunoistoquímica das neoplasias. Por estes motivos, alguns casos foram excluídos do estudo e a casuística obtida não reflete a totalidade dos casos atendidos, não podendo ser utilizada como base epidemiológica.

Obteve-se informação dos animais avaliados de forma retrospectiva por contato telefônico com os proprietários. Já os animais avaliados de forma prospectiva foram acompanhados desde a primeira consulta, durante o póscirúrgico, durante a quimioterapia (quando esta foi realizada) e após o término da quimioterapia, a cada 3 meses, por um período máximo de 27 meses. Os casos que não retornavam na data marcada eram contactados por telefone para obtenção de informações sobre os animais.

\subsection{ESTUDO CLíNICO}

Baseado nos critérios de inclusão e exclusão, foram selecionados 57 animais para este estudo. As fêmeas representaram $61,4 \%$ dos casos e os machos $38,6 \%$, dados semelhantes aos encontrados no estudo de Simões et al. (1994). No entanto, grande parte dos estudos não reportam uma predileção sexual no desenvolvimento do mastocitoma cutâneo canino (FINNIE; BOSTOCK, 1979; PATNAIK; EHLER; MACEWEN, 1984; BOSTOCK, 1986; MACY, 1986; LONDON; SEGUIN, 2003).

Dentre as raças acometidas, os cães sem raça definida $(22,80 \%)$ e os da raça Labrador Retriever (17,54\%) foram os mais prevalentes, seguidos por Golden Retriever (10,52\%), Poodle (8,77\%) e Boxer (7,01\%). Estes resultados são semelhantes aos encontrados na literatura, que referem os cães sem raça definida, Boxer, Labrador e Golden Retriever como mais prevalentes (VILLAMIL et al., 2011; WARLAND; DOBSON, 2013). Entretanto, em relação a raça Boxer, diversos estudos a citam como uma das mais predispostas ao desenvolvimento do mastocitoma (O’KEEFE, 1990; LEMARIÉ et al., 1995; LONDON; SEGUIN, 2003), enquanto que 
neste estudo, ela representou a quinta raça mais frequente. Considerando-se a casuística nacional, Costa-Casagrande et al. (2008) também reportam a ocorrência de mastocitoma em cães sem raça definida em proporções similares as encontradas neste estudo. Boxers, Pugs, assim como outras raças braquicefálicas são descritas na literatura por terem uma tendência a desenvolverem mastocitomas de baixo a intermediário grau e por isso estariam associadas à um melhor prognóstico (BOSTOCK, 1986; McNIEL; PRINK; O'BRIEN, 2004), assim como London e Thamm (2013) referem que há evidências que cães da raça Sharpei exibem um pior prognóstico para a doença. Entretanto, o presente estudo não avaliou a influência da raça no prognóstico da doença.

A faixa etária variou entre 3 e 14 anos, com predominância em animais idosos, com cerca de 9 anos de idade, o que também foi observado nos estudos de London e Seguin (2003); de Strefezzi, Xavier e Catão-Dias (2003) e Blackwood et al. (2012).

Em relação ao número de formações, $77,2 \%$ dos pacientes avaliados apresentavam uma única formação e 22,8\% exibiam múltiplos mastocitomas. A literatura também cita uma prevalência maior de formações únicas e uma taxa de 3$25 \%$ é reportada para mastocitomas múltiplos, similarmente ao que foi observado neste estudo (MACY, 1985; O'KEEFE, 1990; SIMÕES; SCHONING; BUTINE, 1994; MULLINS et al., 2006; MURPHY et al., 2006; THAMM; VAIL, 2007).

De acordo com a literatura, em cerca de $50 \%$ dos casos as formações localizam-se no tronco e região perineal, $40 \%$ em membros e aproximadamente 10\% em região de cabeça e pescoço (PATNAIK; EHLER; MACEWEN, 1984; ROTHWELL et al., 1987; O'KEEFE, 1990; SFILIGOI et al., 2005; WELLE et al., 2008). Em nosso estudo, a localização mais prevalente foram os membros, representando $49,3 \%$ dos mastocitomas, seguido por 40,8\% em região de tronco e períneo e $9,9 \%$ em região de cabeça e pescoço. A localização do tumor é relatada por alguns autores como um fator prognóstico. Mastocitomas em leito ungueal, cavidade oral, nariz, regiões mucocutâneas, região inguinal, prepúcio e períneo estariam associados à um pior prognóstico em comparação aqueles localizados em outras regiões do corpo (AL-SARRAF et al., 1996; BAKER-GABB; HUNT; FRANCE, 2003; GIEGER et al., 2003; THAMM; VAIL, 2007; WELLE et al., 2008). Sfiligoi et al. (2005) observaram menor intervalo livre de doença (9,6 meses) em cães com mastocitoma em região inguinal e períneo em relação aqueles com tumor em outras 
regiões da pele (33,9 meses). No entanto, Cahalane et al. (2004) não observaram um pior prognóstico para mastocitomas em região inguinal e perineal, assim como Stanclift e Gilson (2008) não encontraram associação entre localização anatômica e menor sobrevida ou maior índice de recidiva. Entretanto, a análise de prognóstico em relação a localização anatômica do tumor não foi realizada no presente estudo pois foram excluídos os animais onde o mastocitoma e/ou o linfonodo sentinela não eram passíveis de remoção cirúrgica. Logo, os dados aqui obtidos não refletem a casuística local e não devem ser tomados como base epidemiológica.

O tamanho médio das formações foi de $2,14 \mathrm{~cm}$ de diâmetro, sendo que $12,37 \%$ dos mastocitomas apresentavam ulceração; $43,85 \%$, dos pacientes apresentaram margens comprometidas após o procedimento cirúrgico. Tamanho da neoplasia, assim como a presença de ulceração e margens incompletas são reportados na literatura como fatores prognósticos negativos (THAMM; MAULDIN; VAIL, 1999; LONDON; THAMM, 2013). O estudo de Hahn, King e Carreras (2004) mostrou que cães com mastocitomas maiores que $3 \mathrm{~cm}$ de diâmetro tiveram menor sobrevida em relação aqueles com neoplasia menor que $3 \mathrm{~cm}$. Apesar do tamanho médio dos tumores ter sido de 2,14 cm, deve-se considerar que 49,30\% localizavam-se em membros, dificultando a realização de cirurgia com margens amplas, o que explica a alta taxa de margens comprometidas neste estudo. O estudo de Mullins et al. (2006), que avaliou também diversos fatores prognósticos em cães com mastocitoma, concluiu que formações maiores que $3 \mathrm{~cm}$ e margens comprometidas após a cirurgia influenciaram de forma negativa na sobrevida dos pacientes. Entretanto, apesar do impacto destas variáveis no prognóstico, esta análise não foi realizada no presente estudo.

\subsection{ESTUDO HISTOPATOLÓGICO}

$82,45 \%$ dos animais eram portadores de mastocitoma de grau $2,14,05 \%$ de grau 3 e apenas $3,50 \%$ de grau 1, pela classificação de Patnaik. $87,71 \%$ dos animais exibiam mastocitoma de baixo grau e $12,29 \%$ de alto grau, segundo a classificação de Kiupel. A maior incidência de mastocitomas de grau 2 e de baixo grau neste estudo corrobora com outros estudos descritos na literatura (PATNAIK; 
EHLER; MACEWEN, 1984; BAKER-GABB; HUNT; FRANCE, 2003; DOBSON et al., 2004; KIUPEL et al., 2004; SPUGNINI et al., 2006; BROCKS et al., 2008; TAKEUCHI et al., 2013).

O sistema de graduação de Patnaik é um dos mais comumente utilizados, no entanto, Northrup et al. (2005) citam uma variação interpatologistas e uma predominância no diagnóstico de mastocitomas de grau 2 segundo este sistema de graduação. Já o sistema de graduação de Kiupel, que classifica os mastocitomas apenas em dois graus, foi desenvolvido para diminuir a ambiguidade referente aos mastocitomas de grau intermediário. Diante destes estudos, optamos por utilizar os dois sistemas de classificação histopatológica dos mastocitomas, a fim de facilitar a comparação de nossos resultados com aqueles descritos na literatura.

Em nosso estudo, o grau histológico (Patnaik e Kiupel) associou-se à sobrevida dos animais, independente da presença de metástase em linfonodo. Este resultado está em concordância com outros estudos que afirmam que o grau histológico é considerado um dos fatores prognósticos mais consistentes para cães com mastocitoma cutâneo. Mastocitomas de grau 3 estão associados a menor sobrevida quando comparados aos de grau 1 ou 2 (O'KEEFE, 1990; STREFEZZI et al., 2003; STREFEZZI et al., 2009). Murphy et al. (2004) mostraram que não houve diferença estatística em 1 e 2 anos de sobrevida entre cães com mastocitomas de graus 1 e 2, mas houve diferença significante entre animais com grau 3 e aqueles com graus 1 ou 2. No estudo de Patnaik, Ehler e Macewen (1984), 93\% dos cães com mastocitoma de grau 1 sobreviveram mais de 1500 dias, comparado a $47 \%$ dos cães com grau 2 e apenas 6\% naqueles com grau 3. Kiupel et al. (2011) encontraram uma associação estatisticamente significante entre menor intervalo livre de doença e menor sobrevida nos cães com mastocitomas de alto grau, quando comparados aos cães com mastocitomas de baixo grau, o que também foi reportado do estudo de Vascellari et al. (2012). Kiupel et al. (2011) sugerem ainda a utilização de outros marcadores prognósticos, como a expressão de KIT, marcadores de proliferação celular e a análise da presença de mutação no gene c-kit nos mastocitomas de baixo grau, a fim de determinar com maior precisão o risco de metástase e selecionar o melhor tratamento para estas neoplasias. Takeuchi et al. (2013) comparou ambos os sistemas de graduação do mastocitoma e em seu estudo, o sistema proposto por Kiupel foi clinicamente mais fidedigno para predizer o prognóstico do mastocitoma cutâneo canino. Da mesma forma, Sabattini et al. 
(2014) demonstraram recentemente que a graduação de Kiupel apresentou melhor valor prognóstico em relação àquela proposta por Patnaik. Em nosso estudo, observamos uma associação da graduação de Kiupel com a sobrevida e o intervalo livre de doença, sendo que esta variável teve um maior valor prognóstico quando associada ao índice de marcação pelo Ki-67.

Nenhum mastocitoma de grau 1 e $87 \%$ dos mastocitomas de grau 3 metastatizaram para os linfonodos regionais. Estes dados são semelhantes àqueles relatados na literatura, que reporta um índice de menos de $10 \%$ para os mastocitomas de grau 1 e cerca de 55-96\% para os de grau 3 (BOSTOCK, 1973; WELLE et al., 2008). Nosso índice de metástase nos mastocitomas de grau 3 foi superior ao repostado por Hume et al. (2011), que encontraram 48,8\%, porém nossa amostragem foi consideravelmente menor $(n=8)$ em relação a utilizada no estudo de Hume et al. (2011) ( $n=43)$. Contudo, independente da presença de metástase em linfonodo, o prognóstico de mastocitomas de grau 3 é considerado reservado segundo diversos autores (TURREL et al., 1988; LaDUE et al., 1998; CHAFFIN; THRALL, 2002).

Já para os mastocitomas de grau 2, encontramos um índice de 57,4\% de metástase em linfonodo, que foi superior ao descrito por outros pesquisadores (cerca de 5-22\%) (SEGUIN et al., 2001; WEISSE; SHOFER; SORENMO, 2002), mas foi semelhante ao relatado por Baginski et al. (2014), que reportou $61,1 \%$ de metástase em linfonodo de cães com mastocitoma de grau 2. Baseando-se na classificação de Kiupel, o índice de metástase em linfonodo regional encontrado em nosso estudo foi de $54 \%$ nos animais com mastocitoma de baixo grau e $100 \%$ naqueles com mastocitoma de alto grau.

Entretanto, não encontramos associação estatisticamente significante entre o grau histológico da neoplasia e a presença de metástase em linfonodo, tanto na classificação de Patnaik ( $p=0.1361)$, como na de Kiupel ( $p=0.8415)$. Estes resultados podem ter sido influenciados pela amostra heterogênea com a qual trabalhamos, onde obtivemos diferença significativa

entre os grupos nas classificações de Patnaik $(p<0.001)$ e de Kiupel $(p<$ 0.001 ), com maior prevalência de mastocitomas de grau 2 e de baixo grau. 


\subsection{ESTUDO IMUNOISTOQUÍMICO}

Cerca de $88,2 \%$ das neoplasias expressavam KIT padrão I e II, resultados semelhantes aos encontrados no estudo de Kiupel et al. (2004) onde este índice foi de $86,8 \%$. No entanto, $23,50 \%$ corresponderam a um padrão KIT-II no presente estudo, enquanto que no estudo de Kiupel et al. (2004) este índice foi de 43,9\%.

$O$ índice de metástase linfática foi superior nos animais que apresentavam mastocitomas com padrão KIT-II e KIT-III, em relação aqueles com padrão KIT-I, mas na análise estatística não foi possível uma associação entre a presença de metástase em linfonodo e o padrão de marcação pelo KIT ( $p=0.3340)$, assim como não houve associação do padrão de marcação do KIT com a sobrevida, nem com o intervalo livre de doença. Não há estudos mostrando diretamente uma associação entre presença de metástase regional e padrão de KIT na neoplasia primária. Dados da literatura mostram que cães com padrão KIT-II e III tendem a apresentar menor sobrevida e intervalo livre de doença (KIUPEL et al., 2004; WEBSTER et al., 2008; POGGIANI et al., 2012). Gil da Costa et al. (2007) relataram que a expressão citoplasmática de KIT, tanto focal como difusa, correlacionou-se a fatores prognósticos negativos, como maior grau histológico, maiores índices de proliferação celular, presença de ulceração e maior necrose tumoral. Preziosi, Morini e Sarli (2004), encontraram ainda uma relação significante entre graduação histológica e padrão de imunomarcação do KIT ( $p<0,00000)$. Em nosso estudo todos os animais que apresentaram tumores com padrões KIT-II e KIT-III tinham mastocitomas de grau 2 ou 3, pela graduação de Patnaik. Porém, diferentemente do que foi relatado por Kiupel et al. (2004); Webster et al. (2007); Webster et al. (2008) e Welle et al. (2008), no presente estudo, $44,4 \%$ dos animais que apresentaram progressão da doença exibiam mastocitomas com padrão KIT-I. Esta diferença pode ser explicada pelo elevado número de pacientes com mastocitoma padrão KIT-I nesta casuística, em relação aqueles com padrão KIT-II e KIT-III $(p<0.01)$, contribuindo para uma amostragem heterogênea.

A proteína KIT está presente na membrana citoplasmática de mastócitos bem diferenciados e por isso mastocitomas com este padrão de marcação estariam associados a um menor grau de transformação maligna e tendem a apresentar um comportamento biológico benigno. Por outro lado, mastocitomas de comportamento 
biológico mais agressivo tendem a expressar a proteína KIT no citoplasma. Isto poderia ser explicado pelo papel da proteína KIT e seu ligante, SCF, no desenvolvimento dos mastócitos. KIT e o SCF participam do processo de proliferação, maturação, inibição da apoptose, adesão e migração de mastócitos. $O$ mecanismo exato pelo qual um aumento da expressão de KIT no citoplasma levaria à transformação maligna de mastócitos ainda não foi bem elucidado. Reguera et al. (2000) sugerem que a isoforma citoplasmática de KIT poderia ser ativada pelo SCF solúvel presente ou pela presença de mutação no gene c-kit, que levaria à uma inibição de apoptose e favorecendo a adesão, migração e proliferação dos mastócitos. Diversos estudos já descreveram a presença de mutações no protooncogene c-kit (LONDON et al., 1996; REGUERA et al., 2002; ZEMKE et al., 2002), em cerca de 15-40\% dos mastocitomas cutâneos caninos (LETARD et al., 2008; WELLE et al., 2008). A presença de mutação neste gene está associada a maior ocorrência de recidiva local, metástase e óbito pela doença, sugerindo que a desregulação deste gene confere um fenótipo mais agressivo ao mastocitoma (DOWNING et al., 2002; ZEMKE et al., 2002; WEBSTER et al., 2006), mas o estudo de Takeuchi et al. (2013) não encontrou diferença na sobrevida de pacientes com e sem mutação no gene c-kit. Apesar dos diversos estudos na literatura a respeito da influência da presença de mutação do gene c-kit sobre o prognóstico de cães portadores de mastocitoma cutâneo, o presente estudo limitou-se a investigar o padrão de marcação da proteína KIT nas neoplasias e linfonodos metastáticos, não sendo realizada a análise de mutação no gene c-kit.

Diversos marcadores de proliferação celular já foram estudados no mastocitoma cutâneo canino, como o índice mitótico, proteína Ki-67, PCNA e AgNOR, sendo todos capazes de predizer o prognóstico e resposta à terapia. Entretanto, o índice mitótico e a expressão da proteína Ki-67 são aqueles que apresentam maior valor prognóstico (ABBADIE et al., 1999; SCASE et al., 2006; ROMANSKI et al., 2007; WEBSTER et al., 2007; ELSTON et al., 2009; VASCELLARI et al., 2013).

O marcador de proliferação celular escolhido para este estudo foi o Ki-67, por ser uma proteína nuclear expressa em todas as fases do ciclo celular, determinando o número de células que estão ativamente no ciclo. Além disso, correlaciona-se com o prognóstico e é um marcador independente do grau histológico do mastocitoma, segundo Scase et al. (2006) e Webster et al. (2007). Sakai et al. (2002) consideraram o Ki-67 como padrão ouro de marcação de proliferação celular, sendo 
superior aos anteriormente citados. Diferentes métodos de contagem de células positivas para Ki-67 foram utilizados nos estudos, levando a diferentes pontos de corte no valor do Ki-67 estabelecidos para predizer o prognóstico. O presente estudo baseou-se no método proposto por Webster et al. (2007).

Encontramos uma associação entre a presença de metástase em linfonodo e o índice do Ki-67 da neoplasia primária. Além disso, o índice do Ki-67 associou-se à sobrevida e ao intervalo livre de doença, sendo que todos os animais que vieram a óbito em decorrência do mastocitoma exibiam um valor de Ki-67 acima de 23. Estes dados corroboram os resultados encontrados por Abbadie et al. (1999) e Maglennon et al. (2008), onde o número de núcleos positivos para Ki-67 foi maior nos animais que vieram a óbito pela doença do que naqueles que sobreviveram. Vascellari et al. (2013) também relataram diferença estatística na sobrevida de cães com mastocitomas com índice de Ki-67 acima de 10,6 (valor do ponto de corte) ( $\mathrm{P}=$ 0.006).

Observamos ainda que o índice de marcação pelo Ki-67 quando associado à graduação histológica de Kiupel, melhorou o valor prognóstico deste sistema de classificação histológica, conforme já proposto por outros autores (Kiupel et al., 2011).

Apesar do baixo número de pacientes em nosso estudo que apresentaram progressão da doença $(n=18$ ), em $72,2 \%$ o índice de Ki-67 foi acima de 23, confirmando os resultados encontrados por Webster et al. (2007). Estes autores demonstraram em análise multivariada, que valores de Ki-67 acima de 23 associaram-se a maior incidência de recidiva $(p=0.0111)$, de aparecimento de novo mastocitoma em local distante do local de origem $(p=0.0081)$ e maior mortalidade $(p=0.0022)$.

\subsection{ESTUDO DOS LINFONODOS}

Foram considerados como linfonodos sentinelas aqueles mais próximos à região da neoplasia, baseando-se nos territórios linfáticos do cão descritos no estudo de Suami et al. (2013). Entretanto, realizou-se a linfadenectomia apenas de linfonodos periféricos, excluindo-se os casos onde a neoplasia primária drenava 
para linfonodos intra-abdominais e intratorácicos. Uma vez que 54,90\% das neoplasias localizavam-se em membros pélvicos e região inguinal, mais da metade $(61,70 \%)$ dos linfonodos excisados corresponderam aos linfonodos poplíteos e inguinais. Apesar de outros trabalhos também considerarem como linfonodo sentinela aquele mais próximo à neoplasia (CHAFFIN; THRALL, 2002; WELLE et al., 2008), já foi demonstrado que nem sempre ele representa o linfonodo mais próximo. Herring et al. (2002) avaliou os linfonodos regionais de cães e gatos portadores de neoplasias malignas de cavidade oral ou maxilofaciais. Foram avaliados neste estudo os linfonodos de três linfocentros: mandibular, parotídeo e retrofaríngeo. Dos 31 casos avaliados, 35\% (11/31) exibiam metástase em linfonodos de um ou mais linfocentros, sendo 4 apenas em linfonodos mandibulares, 3 em linfonodos mandibulares e retrofaringeos mediais, 2 apenas em linfonodos parotídeos e 2 com metástase em linfonodos dos três linfocentros. Estudos a respeito da drenagem linfática da região das mamas em cadelas também demonstraram variações anatômicas. Observou-se que neoplasias localizadas na região da mama abdominal caudal, além de drenarem para os linfonodos regionais (inguinais e ilíacos), eventualmente drenam para linfonodos axilares, cervicais superficiais e mediastínicos. Foi demonstrada também anastomose contralateral das vias de drenagem linfática, ou seja, neoplasias localizadas em um lado da cadeia mamária, poderiam metastatizar não só para o linfonodo regional ipsilateral, mas também para o contralateral (PEREIRA et al., 2002; PATSIKAS et al., 2006; PEREIRA et al., 2008). Recentemente, Worley (2014) reportou o mapeamento linfático em 19 cães portadores de mastocitoma cutâneo através da técnica de linfocintilografia associada à aplicação do corante azul de metileno na região peritumoral. Em 8 animais o linfonodo sentinela não correspondeu ao linfonodo regional mais próximo à neoplasia e estes linfonodos eram positivos para metástase na análise histopatológica. Diante deste resultado, foi instituído o tratamento quimioterápico adjuvante a estes pacientes, o que não teria ocorrido sem a identificação destes linfonodos pelo mapeamento linfático. O autor conclui que considerar como LS apenas o linfonodo regional é algo subjetivo e limitado ao fácil acesso cirúrgico aos linfonodos periféricos, como os poplíteos, cervicais superficiais, mandibulares ou linfonodos palpáveis que estejam aumentados.

Apesar de não ter sido um objetivo no presente estudo, a utilização de técnicas de identificação do LS no trans-cirúrgico é um procedimento que deve ser 
adotado na medicina veterinária, conforme demonstrado no estudo de Worley (2014) e de outros autores que realizaram técnicas semelhantes em cadelas e obtiveram resultados satisfatórios (PINHEIRO et al., 2003; AQUINO et al., 2012).

Dos linfonodos positivos para metástase, 52,63\% e 54,68\% apresentavam tamanho e consistência normais à palpação, respectivamente. Estes índices são superiores aos encontrados em outros estudos. Lagenbach et al. (2001) avaliaram linfonodos regionais de cães e gatos com neoplasias sólidas, incluindo o mastocitoma cutâneo canino, por palpação, análise citológica e histopatológica. Dos 15 animais diagnosticados com metástase em linfonodo, apenas um apresentava tamanho normal à palpação. Williams e Packer (2003) reportaram também a associação do tamanho do linfonodo com a presença de metástase em cães com melanoma em cavidade oral. Estes pesquisadores observaram que $30 \%$ dos linfonodos metastáticos eram normais à palpação. A sensibilidade e especificidade do tamanho do linfonodo em prognosticar metástase foi de 70 e 51\%, respectivamente. Ambos os estudos concluem que a palpação não deve ser utilizada como método único na determinação de metástase em linfonodo regional em animais portadores de neoplasias malignas. Vale ressaltar que no presente estudo, $75 \%$ e $76,47 \%$ dos linfonodos metastáticos apresentavam aumento de volume e consistência firme à palpação, respectivamente. Estes linfonodos que exibiam alterações facilmente detectáveis no exame físico apresentavam em sua maioria um padrão de metástase HN2 e HN3. Os linfonodos que exibiam aderência em tecidos subjacentes eram todos metastáticos, similarmente ao encontrado no estudo de Lagenbach et al. (2001). Hottendorf e Nielsen (1968) também reportaram a relação entre o tamanho do linfonodo e a presença de metástase. Em seu estudo, encontraram aumento em 25 de 26 linfonodos metastáticos de cães com mastocitoma que foram avaliados por necropsia. Os animais cujas neoplasias eram localizadas em região posterior do corpo, exibiam aumento bilateral dos linfonodos sublombares, sendo que em alguns, o linfonodo estava cinco vezes acima do seu tamanho normal. Estes autores notaram também que quatro cães possuíam aumento de linfonodos distantes da neoplasia primária, como por exemplo um cão com mastocitoma em região de bolsa escrotal que apresentava aumento dos linfonodos axilar, mediastínico, brônquico, mesentérico, pancreático e sublombares.

Realizamos citologia aspirativa apenas em 46 dos 81 linfonodos excisados, uma vez que a citologia só foi possível em linfonodos palpáveis, mesmo quando não 
aumentados. Além disso, excluímos os casos onde o linfonodo sentinela possuía localização intra-abdominal ou intra-torácica. A literatura reporta que pode-se obter amostras não representativas quando o linfonodo puncionado não estiver aumentado (WORLEY, 2012), mas obtivemos um diagnóstico correto em $75 \%$ dos casos, sendo que $70 \%$ dos linfonodos apresentavam tamanho normal. Encontramos $86 \%$ de sensibilidade e $64 \%$ de especificidade da análise citológica. Este índice foi inferior ao reportado no estudo anteriormente citado, de Lagenbach et al. (2001), onde dos 41 linfonodos sentinela avaliados, em 92,85\% dos casos a citologia corroborou o diagnóstico histopatológico, apresentando $100 \%$ de sensibilidade e $96 \%$ de especificidade. Estes autores concluem que a citologia aspirativa é método confiável para pesquisa de metástase em linfonodo. No entanto, o número de animais com mastocitoma neste estudo foi baixo, representando apenas 6 casos.

Tivemos resultado falso positivo em $13 \%$ das análises citológicas. Isto pode ser explicado por diferenças nas técnicas de coloração nos exames citológico e histológico. Além disso, o significado clínico da presença de poucos mastócitos bem diferenciados, ou mesmo alguns mastócitos atípicos em linfonodos regionais de cães portadores de mastocitoma ainda não foi bem elucidado, uma vez que estas células podem representar uma resposta inflamatória ou mastócitos transitórios no linfonodo, e não uma metástase propriamente dita (BOOKBINDER et al., 1992). Não há um método disponível que possa diferenciar de forma eficaz mastócitos malignos de mastócitos reativos em linfonodos, aspirados de baço, medula-óssea ou esfregaço do sangue periférico. Diante disto, o estadiamento de pacientes com mastocitoma pode tornar-se difícil de ser interpretado (MCMANUS, 1999).

Diversos estudos relatam a falta de um consenso entre os patologistas veterinários a respeito do que constitui um linfonodo metastático em cães com mastocitoma cutâneo. Não há padronização no diagnóstico citológico e histopatológico de metástase em linfonodo nestes animais, principalmente quando mastócitos isolados são observados. As descrições subjetivas e não específicas utilizadas em vários estudos para estabelecer o diagnóstico citológico de metástase linfática são difíceis de se reproduzir e aplicar à população geral de cães portadores desta neoplasia. Alguns dos critérios descritos são: presença de agrupamentos ou fileiras de mastócitos, maior número de mastócitos em dois ou mais campos consecutivos de maior aumento ou a presença de diversos mastócitos pouco diferenciados no linfonodo (GIEGER et al., 2003; CAHALANE et al., 2004; THAMM; 
TUREK; VAIL, 2006). Considerando-se cada critério individualmente, estudos mostram diferentes valores prognósticos entre eles. Quando a presença de agrupamentos ou fileiras de mastócitos num linfonodo é utilizada como critério para definir metástase, no estadiamento da doença, cães com doença em estágio II não tiveram menor sobrevida em relação ao estágio I (THAMM; TUREK; VAIL, 2006). Da mesma forma, se consideramos que a metástase em linfonodo é definida quando há maior número de mastócitos em dois ou mais campos consecutivos de maior aumento, tanto o estadiamento como o tamanho do linfonodo não tiveram impacto na sobrevida em análise multivariada (CAHALANE et al., 2004). Todavia, o estudo de Gieger et al. (2003) demonstrou que a presença de metástase em linfonodo foi um importante fator prognóstico, com impacto na sobrevida. Este estudo avaliou linfonodos regionais de cães portadores de mastocitoma na região do nariz, e o linfonodo foi considerado metastático na presença de elevado número de mastócitos ou na presença de mastócitos pouco diferenciados.

Marconato et al. (2008) demonstraram que a morfometria é um método eficaz e mais sensível na detecção de metástase precoce em linfonodo através do exame citológico. Strefezzi et al. (2003); Maiolino et al. (2005) e Strefezzi et al. (2010) também reportaram a utilização da morfometria como ferramenta auxiliar no diagnóstico e prognóstico do mastocitoma cutâneo canino. Visando validar um critério citológico para diferenciar linfonodos reativos de linfonodos metastáticos em cães com mastocitoma, Krick et al. (2009) realizaram um estudo retrospectivo avaliando a presença de metástase em linfonodo com o grau histológico e a sobrevida dos pacientes. Observou-se que cães com diagnóstico citológico de metástase em linfonodo apresentaram menor sobrevida em relação àqueles que não apresentavam metástase. Além disso, o estadiamento foi considerado um fator prognóstico independente da graduação histológica da neoplasia, sugerindo que a avaliação citológica do linfonodo regional é uma ferramenta útil e relevante no estadiamento do mastocitoma cutâneo canino. O critério proposto por Krick et al. (2009) fornece um método padrão para interpretação de metástase de mastocitoma em linfonodo e que pode ser reproduzido em outros estudos.

Considerando-se a análise histológica dos linfonodos, os mesmos foram corados com Hematoxilina-Eosina, mas realizamos também análise histoquímica pelas colorações azul de toluidina e aldeído-fucsina de Gomori. O azul de toluidina é um corante catiônico que cora os grânulos citoplasmáticos do mastocitoma por 
metacromasia, ou seja, os grânulos adquirem uma coloração diferente (vermelhopúrpura) em relação ao restante do tecido, que ficará azulado. Resultado semelhante é obtido através da técnica de histoquímica com aldeído-fucsina de Gomori, onde os grânulos adquirem uma coloração magenta à avermelhada. Uma vez que estas técnicas não alteram as características histológicas, a literatura recomenda a utilização do azul de toluidina como método complementar à coloração por Hematoxilina-Eosina, auxiliando na identificação de focos de metástase de mastocitoma em linfonodos. No presente estudo, ambas as técnicas de histoquímica evidenciaram a presença de mastócitos nos linfonodos, mas a coloração pelo azul de toluidina mostrou-se superior na identificação dos mastócitos.

Independentemente da técnica utilizada para identificação dos mastócitos em linfonodo, quando a metástase consiste em agrupamentos ou fileiras de mastócitos, ou quando já há perda da arquitetura do linfonodo, o diagnóstico de metástase é facilmente realizado. No entanto, a identificação de mastócitos dispersos ou isolados, sem atipias e em pequena quantidade torna-se um desafio para o patologista. Ainda não há um método eficaz na distinção entre mastócitos neoplásicos e não neoplásicos em linfonodo descrito na literatura. Estudos sobre a avaliação de linfonodo sentinela na oncologia humana reportam a utilização de ensaios moleculares, como o PCR em tempo real como ferramenta auxiliar na detecção de micrometástases em linfonodo (FONSECA et al., 2007; PURDIE, 2007). Tuohy et al. (2009) sugerem a adaptação destas técnicas para a medicina veterinária também. Considerando-se o mastocitoma cutâneo canino, seria possível através desta técnica identificar características na expressão do material genético das células neoplásicas.

Realizamos a classificação do padrão metastático em linfonodo segundo Weishaar et al. (2014) (no prelo) ${ }^{17}$ em 27 animais, dos 34 que apresentavam metástase e encontramos 1 animal com padrão HN0 (3,70\%), 4 com HN1 (14,81\%), 16 com HN2 (59,25\%) e 6 com HN3 (22,22\%). Dos 11 animais que vieram a óbito pela doença, 8 exibiam metástase em linfonodo, sendo 2 HN1, 2 HN2, 3 HN3 e em um animal a avalição não foi possível. Dos animais que exibiam metástase, mas permaneciam vivos ao final do estudo, 1 apresentava padrão HN0, 2 HN1, 14 HN2 e

\footnotetext{
${ }^{17}$ WEISHAAR, K. M.; THAMM, D. H.; WORLEY, D. R.; KAMSTOCK, D. Correlation of nodal mast cells with clinical outcome in dogs with mast cell tumour and a proposed classification system for the evaluation of node metastasis. Journal of Comparative Pathology. (Aceito para publicação em 2014).
} 
3 HN3. Devido a nossa baixa amostragem, não foi possível a obtenção de resultados estatisticamente significativos em relação a possíveis associações dos padrões metastáticos com outros fatores prognósticos avaliados neste estudo. $\mathrm{O}$ estudo de Weishaar et al. (2014) (no prelo) ${ }^{18}$ não encontrou diferença significante no intervalo livre de doença e na sobrevida dos pacientes comparando cada grupo individualmente, devido ao baixo número de animais em cada grupo também. No entanto, quando estes autores dividiram os animais apenas em dois grupos (HNO com HN1 e HN2 com HN3), foi observada uma diferença significante no intervalo livre de doença $(P=0.0224)$ e na sobrevida $(P=0.0225)$, sendo esta de 1824 dias para o grupo HN0/HN1 e 804 dias para o grupo HN2/HN3, pelo teste de GehanBreslow-Wilcoxon.

Para a análise histopatológica dos linfonodos, os mesmos foram previamente cortados ao meio, em corte único longitudinal, para posteriormente serem processados e emblocados em parafina. Realizamos então secções de $5 \mu \mathrm{m}$ de espessura de cada bloco parafinado para a confecção das lâminas e avaliação histológica dos linfonodos. Esta metodologia é rotineiramente utilizada pelos patologistas, mas diversos estudos na oncologia humana já demonstraram um aumento no índice de detecção de metástase em LS realizando-se mais de um corte longitudinal no linfonodo ao invés da realização de mais cortes histológicos no bloco parafinado (WORLEY, 2012; SCHMOLZE et al., 2013). De acordo com o Colégio Americano de Patologistas e a Sociedade Americana de Oncologia Clínica, o protocolo recomendado para a avaliação adequada de linfonodos sentinelas seria a realização de secções seriadas, a cada $2-3 \mathrm{~mm}$ nos linfonodos, além da utilização de técnicas de imunoistoquímica e análise molecular dos linfonodos. Estas técnicas promoveriam uma melhora na detecção de micrometástases, que muitas vezes não são diagnosticadas pelos métodos de avaliação de rotina (DELPECH et al., 2008; WEAVER, 2010; SCHMOLZE, 2013). Estes estudos demonstram a importância na avaliação do LS e devem servir como modelo para uma melhor acurácia no diagnóstico de metástase em linfonodo na medicina veterinária também.

\footnotetext{
${ }^{18}$ WEISHAAR, K. M.; THAMM, D. H.; WORLEY, D. R.; KAMSTOCK, D. Correlation of nodal mast cells with clinical outcome in dogs with mast cell tumour and a proposed classification system for the evaluation of node metastasis. Journal of Comparative Pathology. (Aceito para publicação em 2014).
} 
$\mathrm{Na}$ avaliação imunoistoquímica dos linfonodos, encontramos o mesmo padrão de expressão da proteína KIT na neoplasia primária e no linfonodo metastático em aproximadamente $60 \%$ dos casos. Baseando-se na teoria da expansão clonal de células neoplásicas proposta por Peter Nowell (1976), podemos cogitar que as células metastáticas encontradas nos linfonodos seriam clones de uma subpopulação de células neoplásicas mais resistentes na neoplasia primária. Segundo Nowell (1976), a maioria das neoplasias originam-se como clones de uma única célula. Estudos citogenéticos demonstraram que em diversas neoplasias primárias, todas as células exibiam o mesmo cariótipo anormal, sugerindo uma origem unicelular. Conforme a evolução tumoral, algumas células são eliminadas, por desvantagens metabólicas em relação às outras ou mesmo pelo sistema imunológico do hospedeiro. No entanto, através de um processo de seleção sequencial, algumas células permanecem. Estas células são decorrentes de um processo evolucionário e são resultantes de instabilidades genéticas adquiridas, sendo a partir de então precursoras de uma subpopulação de células neoplásicas. Este ciclo repete-se várias vezes, gerando clones de comportamento biológico cada vez mais agressivo.

Em relação à apresentação clínica da doença, não encontramos uma associação $(P=0.1897)$ entre presença de metástase em linfonodo e o número de formações no momento do diagnóstico. Dados semelhantes foram relatados por Murphy et al. (2006), onde a apresentação clínica da doença (número de formações) não influenciou no prognóstico dos animais. Porém, estes autores mostraram que animais com metástase em linfonodo tiveram menor sobrevida em relação aqueles sem metástase regional $(P=0.023)$, independentemente do número de formações.

\subsection{EVOLUÇÃO DOS CASOS CLÍNICOS}

Consideramos como progressão da doença a ocorrência de recidiva local da neoplasia ou o aparecimento de novo mastocitoma (único ou múltiplos) em local diferente da neoplasia primária, assim como a ocorrência de metástase regional ou à distância, após o procedimento cirúrgico. Entretanto, não há um consenso na literatura se o desenvolvimento de novos mastocitomas representa uma forma 
atípica de metástase ou se os tumores são independentes uns dos outros. Há apenas um estudo que demonstrou origem clonal em 2 cães que desenvolveram novo mastocitoma cerca de 1 ano após exérese da neoplasia primária (ZAVODOVSKAYA; CHIEN; LONDON, 2004). Kiupel et al. (2005) e Preziosi, Sarli e Paltrinieri (2007) afirmam que cães com múltiplos mastocitomas teriam um pior prognóstico, porém, Thamm, Mauldin e Vail (1999); Mullins et al. (2006); Murphy et al. (2006) e Thamm, Turek e Vail (2006) não encontraram esta associação em seus estudos.

Não encontramos associação entre a presença de metástase em linfonodo e a ocorrência de progressão da doença ( $p=0.6148 ; O R=0.03416-4.684$ ), o que também já foi reportado por Cahalane et al. (2004).

Observamos que dos 7 cães com mastocitoma de grau 3 e metástase em linfonodo, 6 vieram a óbito em decorrência da doença. Este resultado é similar ao encontrado por Hahn et al. (2004), que relataram que de 17 cães com mastocitoma de grau 3 que vieram a óbito pela doença, 16 tinham metástase em linfonodo. Já para os mastocitomas de grau 1, apesar do baixo número de cães avaliados $(n=2)$, o prognóstico foi bom; nenhum apresentou metástase em linfonodo nem progressão da doença e os animais permaneciam vivos ao final do estudo. Estes dados estão em concordância com aqueles observados por Murphy et al. (2004) e Vascellari et al. (2013). Segundo Vascellari et al. (2013), cães portadores de mastocitoma de grau 1 possuem bom prognóstico e ao final de seu estudo (com duração de 5 anos), todos permaneciam vivos; já aqueles com mastocitoma de grau 3 vieram a óbito devido recidiva ou metástase do tumor, com sobrevida média de 6 meses; $23 \%$ dos cães com mastocitoma de grau 2 vieram a óbito pela doença. Estes pesquisadores correlacionaram também a graduação de Kiupel à sobrevida, relatando $71 \%$ e 6\% de taxa de mortalidade para os cães com mastocitoma de alto grau e baixo grau, respectivamente. Similarmente, em nosso estudo, dos 7 cães diagnosticados com mastocitoma de alto grau, todos exibiam metástase em linfonodo e 5 (71,4\%) vieram a óbito pela doença. Já para os mastocitomas de baixo grau, tivemos um índice de óbito de $12 \%(6 / 50)$. Nossos resultados sugerem um pior prognóstico nos cães diagnosticados com mastocitoma de grau 3 e de alto grau. Apesar de não termos encontrado uma associação estatisticamente significante entre o grau histopatológico e o índice de metástase em linfonodo, as curvas de Kaplan-Meier 
mostraram que o grau histopatológico (Patnaik e Kiupel) correlacionou-se com a sobrevida dos animais, independente da presença de metástase em linfonodo.

Não encontramos uma associação entre a presença de metástase em linfonodo e o intervalo livre de doença nem a sobrevida nas análiases uni e multivariada, diferentemente do que foi relatado por Sfiligoi et al. (2005), (Welle et al. (2008), Hume et al. (2011) e Poggiani et al. (2012), que encontraram menor sobrevida nos pacientes com metástase em linfonodo no momento do diagnóstico. No entanto, nossos resultados corroboram aqueles reportados no recente estudo de Baginski et al. (2014), que mostraram não haver diferença na sobrevida de cães com e sem metástase em linfonodo $(p=0.133)$. Estes autores avaliaram apenas cães portadores de mastocitomas de grau 2, similarmente à amostra utilizada em nosso estudo, onde $82,45 \%$ de cães tinham este diagnóstico. Da mesma forma, Cooper, Tsai e Bennet (2009) mostraram que o status do linfonodo não influenciou na sobrevida de cães com mastocitoma, mas os autores referem que este resultado possa ter sido obtido devido ao baixo número de pacientes selecionados para o estudo ( $n=57$ ), que foi exatamente o mesmo número que utilizamos para esta pesquisa. Concluem ainda que uma associação entre presença de metástase em linfonodo e evolução da doença ainda não foi completamente elucidada. Dobson, Cohen e Goud (2004) também não encontraram associação entre metástase em linfonodo e intervalo livre de doença, referindo que 65\% dos animais positivos para metástase em linfonodo permaneciam vivos e livres de doença ao final do estudo. Este índice foi discretamente superior ao encontrado neste projeto, onde dos 43 animais que permaneciam vivos, 58\% apresentavam metástase em linfonodo no momento do diagnóstico.

O número de pacientes utilizados no estudo, o baixo número de eventos (óbito, recidiva ou nova formação) e o fato de não termos trabalhado com uma amostra homogênea, que foi demonstrado pela diferença significativa entre 0 número de cães com mastocitoma de grau 2 em relação aos graus 1 e 3 ( $p<0.001)$, assim como o elevado número de cães com mastocitoma de baixo grau em relação aqueles com mastocitoma de alto grau ( $p<0.01$ ), pode ter influenciado nos resultados finais.

De forma geral, diversos autores sugerem que pacientes com mastocitoma de qualquer grau e que tenham envolvimento de linfonodo regional, possuem um risco maior de óbito decorrente da doença (TURREL et al., 1988; AYL et al., 1992; 
GERRITSEN et al., 1998; THAMM; MAULDIN; VAIL, 1999; THAMM; VAIL, 2003). Entretanto, além do grau histológico, devemos considerar outros fatores prognósticos que já são bem estabelecidos para o mastocitoma cutâneo canino, como o padrão de expressão da proteína KIT, a presença de mutação no gene c-kit, o índice de células positivas para a proteína Ki-67, índice mitótico, tamanho e localização da neoplasia, obtenção de margens livres após procedimento cirúrgico e principalmente a utilização de terapia adjuvante, como a quimioterapia e/ou radioterapia, que interferem de forma significante no controle da doença e sobrevida destes pacientes (LONDON et al., 1999; CHAFFIN; THRALL, 2002; HAHN; KING; CARRERAS, 2004; KIUPEL et al., 2004; MULLINS et al., 2006; SCASE et al., 2006; THAMM; VAIL; TUREK, 2006; WEBSTER et al., 2007; ELSTON et al., 2009; BLACKWOOD et al., 2012).

Ainda sobre a falta associação da presença de metástase em linfonodo com a o intervalo livre de doença e a sobrevida dos animais neste estudo, um ponto importante a ser considerado é que $73,68 \%$ dos animais receberam tratamento quimioterápico e diversos estudos já demonstraram o impacto da quimioterapia e/ou radioterapia no intervalo livre de doença e sobrevida de cães diagnosticados com mastocitoma cutâneo. Thamm, Mauldin e Vail (1999) avaliaram o uso da vimblastina e prednisona como tratamento adjuvante em cães com mastocitoma, sendo que dos 41 animais avaliados, 53,6\% apresentavam metástase em linfonodo. Estes autores relataram $57 \%$ de intervalo livre de doença em 1 e 2 anos, sendo que nos cães com mastocitoma de grau 3, o tempo médio de sobrevida foi de 331 dias, demonstrando melhores resultados em relação a outros estudos que utilizaram apenas a cirurgia como tratamento (BOSTOCK, 1973; PATNAIK; EHLER; MACEWEEN, 1984; BOSTOCK et al., 1989). Webster et al. (2008) demonstraram da mesma forma que o uso da quimioterapia adjuvante com vimblastina e prednisona, associada ou não à radioterapia, beneficiou principalmente cães com mastocitoma de grau 3, quando comparados aqueles animais que receberam apenas cirurgia como tratamento. Este estudo não considerou o status do linfonodo como fator prognóstico, mas confirmou o valor prognóstico de outras variáveis como grau histológico, presença de mutação no gene c-kit, padrão de expressão da proteína KIT e valor de Ki-67. Hayes et al. (2007) também avaliaram o efeito da quimioterapia com vimblastina e prednisona em cães com mastocitoma de grau 3 e observaram um melhor prognóstico. Dos animais sem evidência de metástase em linfonodo, nenhum veio a óbito por 
progressão da doença e aqueles que apresentavam metástase, estavam vivos cerca de 481 dias (variando entre 321 e 833 dias) após o diagnóstico.

Turrel et al. (1988) relataram que animais com mastocitomas únicos, sem evidência de metástase em linfonodo e que receberam radioterapia adjuvante, apresentaram melhor evolução clínica do que aqueles com metástase em linfonodo. Já no estudo de Chaffin e Thrall (2002), cães com mastocitoma e metástase em linfonodo receberam radioterapia adjuvante associada a prednisona oral; o intervalo livre de doença foi longo (40 meses), mas 31\% dos animais apresentaram progressão da doença no primeiro ano após o tratamento. Ainda avaliando a resposta ao tratamento em cães com metástase em linfonodo, o estudo de Rassnick et al. (2010) mostrou melhores resultados. Estes autores utilizaram um protocolo quimioterápico incluindo lomustina, vimblastina e prednisona em cães com mastocitoma de grau 2 e obtiveram 31,2 meses de intervalo livre de doença. Quando associou-se a radioterapia a este protocolo, o intervalo livre de doença aumentou, variando entre 31 e 61 meses (mediana de 38 meses).

$O$ fato de que todos os pacientes do estudo foram submetidos à linfadenectomia e mais de $70 \%$ recebeu tratamento quimioterápico adjuvante pode ter contribuído para o alto índice de animais vivos ao final do estudo. A conduta terapêutica adotada e os resultados obtidos neste estudo corroboram o que foi reportado por Chaffin e Thrall (2002) e Thamm, Turek e Vail (2006), onde cães em estágio II da doença, ou seja, presença de formação única com metástase em linfonodo regional, podem ter uma sobrevida semelhante aqueles animais em estágio 0 ou estágio I da doença, desde que recebam tratamento apropriado.

Poirier et al. (2006) não recomendam a radioterapia profilática do linfonodo regional em mastocitomas de baixo a intermediário grau, uma vez que seu potencial metástastico é baixo. Entretanto, em nosso estudo o índice de metástase regional nos cães com mastocitoma de grau 2 foi de 57,4\%, similar ao que é descrito na literatura para os mastocitomas de grau 3.

Diante destes resultados e segundo recomendado por diversos autores, 0 tratamento do linfonodo metastático, seja por radioterapia, ou através da linfadenectomia, independentemente do resultado da citologia, pode beneficiar pacientes com diagnóstico de mastocitoma cutâneo, contribuindo para melhores índices de sobrevida nestes animais (LADUE et al., 1998; HAHN; KING; CARRERAS, 2004; THAMM; TUREK; VAIL, 2006). 


\subsection{CONSIDERAÇÕES FINAIS}

O principal objetivo neste estudo foi mostrar o impacto da presença de metástase em linfonodos regionais na sobrevida de cães portadores de mastocitoma cutâneo. Apesar de mais da metade dos pacientes apresentarem metástase em linfonodo, surpreendentemente não encontramos uma associação significativa da presença de metástase com o intervalo livre de doença, nem com a sobrevida destes animais. Entretanto, alguns pontos importantes podem ter contribuído para este resultado inesperado. $O$ primeiro seria a amostra heterogênea com a qual trabalhamos, onde mais de $80 \%$ dos animais possuíam mastocitomas de grau 2 e de baixo grau. $O$ baixo número de animais com mastocitomas de graus 1 e 3 (pela graduação de Patnaik) e de alto grau (pela graduação de Kiupel) interferiram de forma negativa nas análises estatísticas, de forma que não conseguimos correlacionar o grau histológico à frequência de metástase em linfonodo, sendo que diversos autores já reportaram que o grau histológico é um dos principais fatores prognósticos no mastocitoma cutâneo canino, além de associar-se ao índice metastático.

O padrão de expressão da proteína KIT também foi descrito como um fator prognóstico em diversos estudos e para esta variável, também obtivemos uma amostra heterogênea, com uma prevalência de mastocitomas com padrão KIT I, o que novamente dificultou a análise estatística. A única variável que correlacionou à presença de metástase em linfonodo foi o índice de núcleos marcados pelo Ki-67 na neoplasia primária, sendo que para esta variável, conseguimos grupos mais homogêneos.

Outro ponto a ser considerado é que grande parte dos casos foram avaliados de forma prospectiva, a partir do início deste estudo, portanto, por período de no máximo dois anos. Desta forma, não pudemos obter dados sobre a evolução dos animais por um período maior, conforme é relatado em outros estudos.

Um dos fatos que mais dificultou nossas análises, foi o baixo número de animais que vieram a óbito e que apresentaram progressão da doença. Por outro lado, este dado chama a atenção, pois cerca de $58 \%$ dos animais que permaneciam 
vivos ao final do estudo, exibiam metástase em linfonodo no momento do diagnóstico. Esta evolução favorável dos casos pode ser atribuída exatamente ao fato de termos realizado a linfadenectomia em todos os pacientes portadores de mastocitoma cutâneo, independentemente do resultado prévio da citologia. Os recentes estudos de Hume et al. (2011) e Baginski et al. (2014) reportaram que cães com linfonodos positivos para metástase de mastocitoma, que receberam tratamento (seja a linfadenectomia ou a radioterapia no linfonodo) apresentaram maior sobrevida. Não tivemos um grupo controle em nosso estudo, que seria representado por animais onde não foi realizada a linfadenectomia. No entanto, o estudo de Costa-Casagrande (2010) mostrou que de 81 cães com mastocitoma, 22\% apresentavam metástase em linfonodo no momento do diagnóstico (análise por exame citológico apenas). Os procedimentos estabelecidos nesse estudo não incluíam a realização de linfadenectomia. Ao final do estudo, 39 animais evoluíram para metástase, sendo $76,9 \%$ dos casos para linfonodos, e houve uma associação significativa entre a presença de metástase em linfonodo e o óbito $(p=0.01)$. Em nosso estudo, conforme já relatado por outros autores anteriormente citados, os animais diagnosticados com metástase em linfonodo sentinela podem ter beneficiado-se com a linfadenectomia.

Além da retirada do linfonodo, mais de $70 \%$ dos cães em nosso estudo receberam tratamento quimioterápico adjuvante, mas esta variável não foi incluída em nossas análises estatísticas. Conforme descrito previamente, de acordo com diversos autores, a quimioterapia é capaz de prolongar o intervalo livre de doença e a sobrevida em cães com mastocitoma cutâneo que apresentem metástase em linfonodo e/ou margens cirúrgicas comprometidas. Acreditamos que este alto índice de pacientes que receberam tratamento quimioterápico também tenha influenciado em nossos resultados, de forma que não foi possível alcançar o intervalo livre de doença e o tempo de sobrevida ao final do estudo, nos animais com e sem metástase em linfonodo.

Apesar dos resultados não esperados, vários autores já demonstraram a importância da análise do linfonodo sentinela no estadiamento, planejamento terapêutico, assim como no prognóstico de diversas neoplasias, tanto na oncologia humana, como na veterinária, que foi o que nos motivou a realizar este estudo. 
CONCLUSÕES 


\section{CONCLUSÕES}

Diante dos resultados obtidos podemos concluir que:

a citologia mostrou-se um método com boa sensibilidade para o diagnóstico de metástase em linfonodos regionais de cães portadores de mastocitoma cutâneo, mas ainda assim não exclui a necessidade do exame histopatológico;

* não houve associação entre o número de formações que o animal apresentava no momento do diagnóstico e a presença de metástase em linfonodo;

* as graduações histológicas de Patnaik e Kiupel não mostraram correlação com a presença de metástase em linfonodo, mas associaram-se à sobrevida;

* a graduação de Kiupel junto ao padrão de marcação do Ki-67 mostrou melhor valor prognóstico em relação apenas a graduação histológica, independentemente da presença de metástase em linfonodo;

* os padrões de marcação do KIT na neoplasia primária não puderam ser correlacionados à presença de metástase em linfonodo nem a sobrevida e o intervalo livre de doença;

* a marcação com Ki-67 na neoplasia primária mostrou forte associação com a presença de metástase em linfonodo

* não foi possível uma correlação dos diferentes padrões de metástase em linfonodos com nenhuma das variáveis analisadas;

* não houve associação entre a presença de metástase em linfonodo e o intervalo livre de doença, nem a sobrevida nos cães portadores de mastocitoma cutâneo. 
REFERÊNCIAS 


\section{REFERÊNCIAS}

ABADIE, J. J.; AMARDEILH, M. A.; DELVERDIER, M. E. Immunohistochemical detection of proliferating cell nuclear antigen and Ki-67 in mast cell tumors from dogs. Journal of the American Veterinary Medical Association, v. 215, p. 1629-1634, 1999.

AYL, R. D.; COUTO, C. G.; HAMMER, A. S.; WEISBRODE, S.; ERICSON, J. G.; MATHES, L. Correlation of DNA ploidy to tumor histologic grade, clinical variables and survival in dogs with mast cell tumors. Veterinary Pathology, v. 29, p. 386-390, 1992.

ALITALO, K.; TAMMELA, T.; PETROVA, T. V. Lymphangiogenesis in development and human disease. Nature, v. 438, n. 7070, p. 946-953, 2005.

AMAGAI, Y.; TANAKA, A.; MATSUDA, A.; MATSUDA, H. Heterogeneity of internal tandem duplications in the c-kit of dogs with multiple mast cell tumours. Journal of Small Animal Practice, v. 54, p. 377-380, 2013.

AMAGAI, Y.; TANAKA, A.; MATSUDA, A.; MATSUDA, H. Increased expression of the antiapoptotic protein MCL1 in canine mast cell tumors. Journal of Veterinary Medical Science, v. 75, n. 7, p. 971-974, 2013.

AMMENDOLA, M.; SACCO, R.; DONATO, G.; ZUCCALA, V.; RUSSO, E.; LUPOSELLA, M.; RANIERI, G. Mast cell positivity to tryptase correlates with metastatic lymph nodes in gastrointestinal cancer patients treated surgically. Oncology, v. 85, n. 2, p. 111-116, jan. 2013.

ANDERSON, D. M.; LYMAN, S. D.; BAIRD, A.; WIGNALL, J.; EISENMAN, J.; RAUCH, C.; MARCH, C. J.; BOSWELL, H. S.; GIMPEL, S. D.; COSMAN, D.; WILLIAMS, D. E. Molecular cloning of mast cell growth fator, a hematopoietin that is active in both membrane bound and soluble forms. Cell, v. 63, p. 235-243, 1990.

AQUINO, J. U.; PINHEIRO, L. G. P.; DIOGENES, P. H.; ROCHA, J. I. X.; CRUZ, D. A.; BESERRA, H. E. O.; CAVALCANTE, R. V. Modelo canino experimental para a pesquisa do linfonodo sentinela na vulva usando tecnécio e azul patente. Acta Cirúrgica Brasileira, v. 27, n. 2, p. 102-108, 2012.

AYL, R. D.; COUTO, C. G.; HAMMER, A. S.; WEISBRODE, S.; ERICSON, J. G.; MATHES, L. Correlation of DNA ploidy to tumor histologic grade, clinical variables 
and survival in dogs with mast cell tumors. Veterinary Pathology, v. 29, p. 386-390, 1992.

BAGINSKI, H.; DAVIS, G.; BASTIAN, R. P. The prognostic value of lymph node metastasis with grade 2 MCTs in dogs: 55 cases (2001-2010). Journal of the American Animal Hospital Association, v. 50, n. 2, p. 89-95, 2014.

BAKER-GABB, M.; HUNT, G. B.; FRANCE, M. P. Soft tissue sarcomas and mast cell tumours in dogs; clinical behavior and responses to surgery. Australian Veterinary Journal, v. 81, n. 12, p. 732-738, 2003.

BALIGA, B. C.; KUMAR, S. Role of bcl-2 family of proteins in malignancy. Journal of Hematology and Oncology, v. 20, p. 63-74, 2002.

BANERJI, S.; NI, J.; WANG, S. X.; CLASPER, S.; SU, J.; TAMMI, R.; JACKSON, D. G. LYVE-1, a new homologue of the CD44 glycoprotein, is a lymph-specific receptor for hyaluronan. Journal of Cell Biology, v. 144, n. 4, p. 789-801, 1999.

BERGMAN, P. J. Canine oral melanoma. Clinical Techniques in Small Animal Practice, v. 22, p. 55-60, 2007.

BERLATO, D.; STEWART, J.; NEWTON, R.; MAGLENNON, G. A.; MONTI, P.; FLINDALL, A.; MURPHY, S. Evaluation of minichromosome maintenance protein 7 as a prognostic marker in canine cutaneous mast cell tumours. Veterinary and Comparative Oncology, v. 10, n. 2, p. 135-142, 2012.

BLACKWOOD, L.; MURPHY, S.; BURACCO, P.; DE VOS, J. P.; DE FORNELTHIBAUD, P.; HIRSCHBERGER, J.; KESSLER, M.; PASTOR, J.; PONDE, F.; SAVARY-BATAILE, K.; ARGYLE, D. J. European consensus document on mast cell tumours in dogs and cats. Veterinary and Comparative Oncology, v. 10, n. 3, 2012.

BONNEMA, J.; VAN DE VELDE, C. J. H. Sentinel lymph node biopsy in breast cancer. Annals of Oncology, v. 13, p. 1531-1537, 2002.

BOOK, A. P.; FIDEL, J.; WILLS, T.; BRYAN J.; SELLON, R.; MATTOON, J. Correlation of ultrasound findings, liver and spleen cytology, and prognosis in the clinical staging of high metastatic risk canine mast cell tumors. Veterinary Radiology and Ultrasound, v. 52, n. 5, p. 548-554, 2011. 
BOSTOCK, D. E. The prognosis following surgycal removal of mastocytomas in dogs. Journal of the Small Animal Practice, v. 14, p. 27-41, 1973.

BOSTOCK, D. E. Neoplasms of the skin and subcutaneous tissues in dogs and cats. British Veterinary Journal, v. 142, n.1, p. 1-19, 1986.

BOSTOCK, D. E.; CROCKER, J.; HARRIS, K.; SMITH, P. Nucleolar organizer regions as indicators of post-surgical prognosis in canine spontaneous mast cell tumors. British Journal of Cancer, v. 59, p. 915-918, 1989.

BROCKS, B. A. W.; NEYENS, I. J.; TESKE, E.; KIRPENSTEIJN, J. Hypotonic water as adjuvant therapy for incompletely resected canine mast cell tumors: $A$ randomized, double-blind, placebo-controlled study. Veterinary Surgery, v. 37, n. 5, p. 472-478, 2008.

CABANAS, R. M. An approach for the treatment of penile carcinoma. Cancer, v. 39, p. 456-466, 1977.

CAHALANE, A. K.; PAYNE, S.; BARBER, L. G.; DUDA, L. E.; HENRY, C. J.; MAULDIN, G. E.; GELNNA, E.; FRIMBERGER, A. E.; COTTER, M. S.; MOORE, S. A. Prognostic factors for survival of dogs with inguinal and perineal mast cell tumors. Journal of the American Veterinary Medical Association, v. 225, n. 3, p. 401408, 2004a.

CAHALANE, A. K.; PAYNE, S.; BARBER, L. G.; DUDA, L. E.; HENRY, C. J.; MAULDIN, G. E.; GELNNA, E.; FRIMBERGER, A. E.; COTTER, M. S.; MOORE, S. A. Prognostic factors for survival of dogs with inguinal and perineal mast cell tumors treated surgically with or without adjunctive treatment: 68 cases (1994-2002).

Journal of the American Veterinary Medical Association, v. 225, n. 3, p. 401408, 2004b.

CAMPS-PALAU, M. A.; LEIBMAN, N. F.; ELMSLIE, R.; LANA, S. E.; PLAZA, S.; MCNIGHT, J. A.; RISBON, R.; BERGMAN, P. J. Treatment of canine mast cell tumours with vinblastine, cyclophosphamide and prednisone: 35 cases (1997-2004). Veterinary and Comparative Oncology, v. 5, n. 3, p. 156-167, 2007. CANNAS, S. J. P.; SCHONING, P. Canine mast cell tumors: a comparision of staining techniques. Journal of Veterinary Diagnostic Investigation, v. 6, p. 458465, 1994.

CARLSTEN, K. S.; LONDON, C. A.; HANEY, S.; BURNETT, R.; AVERY, A. C.; THAMM, D. H. Multicenter prospective trial of hypofractionated radiation treatment, 
toceranib, and prednisone for measurable canine mast cell tumors. Journal of Veterinary Internal Medicine, v. 26, n. 1, p. 135-141, 2012.

CARSON, F. L. Histotechnology, 2. ed. Chicago: ASCP Press, 1997. p. 154-155.

CAYATTE, S.M.; MCMANUS, P.M.; MILLER, W. H. J.; SCOTT, D. W. Identification of mast cells in buffy coat preparations from dogs with inflammatory skin diseases. Journal of the American Veterinary Medical Association, v. 206, p. 325-326, 1995.

CHAFFIN, K.; THRALL, D. Results of radiation therapy in 19 dogs with cutaneous mast cell tumor and regional lymph node metastasis. Veterinary Radiology \& Ultrasound, v. 43, n. 4, p. 392-395, 2002.

CHENG, J. C.; JONES, P. A. Epigenetics events in câncer. In: KNOWLES, M. A.; SELBY, P. J. Cellular and molecular biology of cancer. 4. ed. New York: Oxford University Press, 2005. cap. 5, p. 78-94.

CIRILLO, J. V. Avaliação citológica e histopatológica de linfonodos regionais em cães portadores de mastocitomas de graus 1, 2 ou 3 e sua importância na determinação da sobrevida. 2015. 159 f. Dissertação (Mestrado em Ciências) - Faculdade de Medicina Veterinária e Zootecnia, Universidade de São Paulo, São Paulo, 2014.

COLE, W. Mast cell tumor in a puppy. Canadian Veterinary Journal, v. 31, p. 457, 1990.

COOPER, M.; TSAI, X.; BENNETT, P. Combination CCNU and Vinblastine chemotherapy for canine mast cell tumours: 57 cases. Veterinary and Comparative Oncology, v.7, n. 3, p. 196-206, 2009.

COSTA-CASAGRANDE, T. A., ELIAS, D. S., MELO, S. R., MATERA, J. M. Estudo retrospectivo do mastocitoma canino no Serviço de Cirurgia de Pequenos Animais Hospital Veterinário da Faculdade de Medicina Veterinária e Zootecnia da Universidade de São Paulo. Archives of Veterinary Science, v. 13, n. 3, p. 206213, 2008.

COWELL, R. L.; DORDEY, K. E.; MEINKOTH, J. H. Lymph node cytology. The Veterinary Clinics: Small Animal Practice, v. 33, p. 47-67, 2003.

CSERNI, G.; BIANCHI, S.; VEZZOSI, V.; PETERSE, H.; SAPINO, A.; ARISIO, R.; REINER-CONCIN, A.; REGITNIG, P.; BELLOCQ, J-P.; MARIN, C.; BORI, R.; 
PENUELA, J. M.; ITURRIAGAGOITIA, A. C. The value of cytokeratin immunohistochemistry in the evaluation of axilary sentinel lymph nodes in patients with lobular breast carcinoma. Journal of Clinical Pathology, v. 59, p. 518-522, 2006.

DADRAS, S. S.; LANGE-ASSCHENFELDT, B.; VELASCO, P.; NGUYEN, L.; VORA, A.; MUZIKANSKY, A.; JAHNKE, K.; HAUSCILD, A.; HIRAKAWA, S.; MIHM, C. M.; DETMAR, M. Tumor lymphangiogenesis predicts melanoma metastasis to sentinel lymph nodes. Modern pathology, v. 18, n. 9, p. 1232-1242, 2005.

DAGLI, M. L. Z.; GUERRA, J. L.; SALDIVA, P. M. N. Na experimental study on the lymphatic dissemination of the solid ehrlich tumor in mice. Brazilian Journal of Veterinary Research and Animal Science, v. 29, n. 1, p. 97-103, 1992.

DA SILVA, E. Z. M.; JAMUR, M. C.; OLIVER, C. Mast cell function: a new vision of an old cell. Journal of Histochemistry \& Cytochemistry, v. 7, p. 1-151, 2014.

DOBSON, J.; COHEN, S.; GOULD, S. Treatment of canine mast cell tumors with prednisolone and radiotherapy. Veterinary and Comparative Oncology, v. 2, n. 3, p. 132-141, 2004.

DOBSON, J. M.; SCASE, T. J. Advances in the diagnosis and management of cutaneous mast cell tumours in dogs. The Journal of Small Animal Practice, v. 48, n. 8, p. 424-431, ago. 2007.

DUNCAN, J. The lymph nodes. In: Diagnostic cytology and haematology of the dog and cat. 2. ed. St. Louis, MO: Mosby, 1999. p. 97-103.

EGGER, M. E.; BOWER, M. R.; CZYSZCZON, I. A.; FARGHALY, H.; NOYES, R. D.; REINTGEN, D. S.; MARTIN, R. C. G.; SCOGGINS, C. R.; STROMBERG, A. J.; MCMASTERS, K. M. Comparison of sentinel lymph node micrometastatic tumor burden measurements in melanoma. Journal of the American College of Surgeons, v. 218, n. 4, p. 519-528, 2014.

ELSTON, L. B.; SUEIRO, F. A.; CAVALCANTI, J. N.; METZE, K. The importance of the mitotic índex as a prognostic factor for survival of canine cutaneous mast cell tumors: a validation study. Veterinary Pathology, v. 46, p. 362-364, 2009.

EVANS H. J. Molecular genetic aspects of human cancers: the 1993 Frank Rose Lecture. British Journal of Cancer, v.68, p. 1051-1060, 1993. 
FINNIE, J. W.; BOSTOCK, D. E. Skin neoplasia in dogs. Australian Veterinary Journal, v. 55, p. 602-604, 1979.

FINORA, K.; LEIBMAN, N. F.; FETTMAN, M. J.; POWERS, B. E.; HACKETT, T. A.; WITHROW, S. J. Cytological comparison of fine-needle aspirates of livre and spleen of noral dogs and dogs with cutaneous mast cell tumors and an ultrasonographically normal appearing liver and spleen. Veterinary and Comparative Oncology, v. 4, n. 3, p. 178-183, 2006.

FOSSLIEN, E. Molecular pathology of cyclooxigenase-2 in neoplasia. Annals of Clinical \& Laboratory Science, v. 30, p. 3-21, 2000.

FOX, L. E. Mast cell tumors. In: MORRISON, W.B. Cancer in dogs and cats medical and surgical management. Philadelphia: Linppincott Williams \& Wilkins, 1998. Cap. 30, p. 479-488.

FOX, L. E.; ROSENTHAL, R. C., TWEDT, D. C., DUBIELZIG, R. R.; MACEWEN, E. G.; GRAUER, G. F. Plasma histamine and gastrin-concentrations in 17 dogs with mast cell tumors. Journal of Veterinary Internal Medicine, v. 4, p. 242-246, 1990.

FRIMBERGER, A. E.; MOORE, A. S.; CINCOTTA, L., COTTER, S. M.; FOLEY, J. W. Photodynamic therapy of naturally occurring tumors in animals using a novel benzophenothiazine photosensitizer. Clinical Cancer Research, v. 4. p. 2207-2218, 1998.

FRIMBERGER, A. E.; MOORE, A. S.; LARUE, S. M. Radiotherapy of incompletely resected, moderately differentiated mast cell tumors in the dog: 37 cases (19891993). Journal of the American Animal Hospital Association, v. 33, p. 320-324, 1997.

FULCHER, R. P.; LUDWIG, L. L.; BERGMAN, P. J.; NEWMAN, S. J.; SIMPSON, A. M.; PATNAIK, A. K. Evaluation of a two-centimeter lateral surgical margin for excision of grade I and grade II cutaneous mast cell tumors in dogs. Journal of the American Veterinary Medical Association, v. 228, n. 2, p. 210-215, 2006.

GADD, M. A.; COSIMI, A. B.; DUNCAN, L. M.; YU, L.; FLOTTE, T. J.; TANABE, K. K. Outcome of patients with melanoma and histologically negative sentibel lymph nodes. Archives os Surgery, v. 134, p. 381-387, 1999.

GIANTIN, M.; ARESU, L.; BENALI, S.; ARICO, A.; MORELLO, E. M.; MARTANO, M.; DACASTO, M. Expression of matrix metalloproteinases, tissue inhibitors of 
metalloproteinases and vascular endothelial growth factor in canine mast cell tumours. Journal of Comparative Pathology, v. 147, n. 4, p. 419-429, 2012.

GIANTIN, M.; VASCELLARI, M.; MORELLO, E. M.; CAPELLO, K.; VERCELLI, A.; GRANATO, A.; DACASTO, M. C-KIT messenger RNA and protein expression and mutations in canine cutaneous mast cell tumors: correlations with post-surgical prognosis. Journal of Veterinary Diagnostic Investigation, v. 24, n. 1, p. 116-126, 2012.

GIEGER, T. L.; THEON, A. P.; WERNER, J. A.; MCENTEE, M. C.; RASSNICK, K. M.; DECOCK, H. E. V. Biologic behavior and prognostic factors for mast cell tumors of the canine muzzle: 24 cases (1990-2001). Journal of Veterinary Internal Medicine, v. 17, p. 687-692, 2003.

GIL DA COSTA, R. M.; MATOS, E.; REMA, A.; LOPES, C.; PIRES, M. A.; GÄRTNER, F. CD117 immunoexpression in canine mast cell tumours: correlations with pathological variables and proliferation markers. BMC Veterinary Research, v. 3 , n. 19, p. 1-7, 2007.

GILFILLAN, A. M.; TKACZYK, C. Integrated signaling pathways for mast-cell activation. Nature Reviews Immunology, v. 6, n. 3, p. 203-218, 2006.

GILSON, S. D. Clinical management of the regional lymph node. Veterinary Clinics of North America: Small Animal Practice, v. 25, p. 149-167, 1995.

GINN, P. E.; FOX, L. E.; BROWER, J. C.; GASKIN, A.; KURSMAN, I. D.; KUBILIS, P. $\mathrm{S}$. Immunohistochemical detection of p53 tumor-supressor protein is a poor indicator of prognosis for canine cutaneous mast cell tumors. Veterinary Pathology, v. 37, n. 1, p. 33-39, 2000.

GIULIANO, A. E.; KIRGAN, D. M.; GUENTHER, J. M.; MORTON, D. L. Lymphatic mapping and sentinel lymphadenectomy for breast cancer. Annals of Surgery, v. 220, p. 391-401, 1994.

GONZALEZ, M. A.; TACHIBANA, K. E.; LASKEY, R. A.; COLEMAN, N. Control of DNA replication and its potential clinical exploitation. Nature Reviews Cancer, v. 5, p. 135-141, 2005.

GOULD, E. A.; WINSHIP, T.; PHILBIN, P. H.; HYLAND KERR, H. Observations on a "sentinel node" in cancer of the parotid. Cancer, v. 13, p. 77-78, 1960. 
GOVIER, S. M. Principles of treatment for mast cell tumors. Clinical Techniques in Small Animal Practice, v. 18, p. 103-106, 2003.

GRANO, F. G.; SILVA, J. E.; MELO, G. D.; SCHWEIGERT, A.; CIARLINI, P. C.; MACHADO, G. F. Visceral mast cell tumor and mastocythemia in a dog. Brazilian Journal of Veterinary Pathology, v. 5, n. 3, p. 142-145, 2012.

GRANT, I. A.; RODRIGUEZ, C. O.; KENT, M. S.; SFILIGOI, G.; GORDON, I.; DAVIS, G.; LORD, L.; LONDON, C. A. A phase II clinical trial of vinorelbine in dogs with cutaneous mast cell tumors. Journal of Veterinary Internal Medicine, v. 22, n. 2, p. 388-393, 2008.

HAHN, K. A.; KING, G. K.; CARRERAS, J. K. Efficacy of radiation therapy for incompletely resected grade-III mast cell tumors in dogs: 31 cases (1987-1998). Journal of the American Veterinary Medical Association, v. 224, n. 1, p. 79-82, 2004.

HAHN, K. A.; OGILVIE, G.; RUSK, T.; DEVAUCHELLE, P.; LEBLANC, A.; LEGENDRE, A.; POWERS, B.; LEVENTHAL, P. S.; KINET, P. J.; PALMERINI, F.; DUBREUIL, P.; MOUSSY, A.; HERMINE, O. Masitinib is safe and effective for the treatment of canine mast cell tumors. Journal of Veterinary Internal Medicine, $v$. 22, n. 6, p. 1301-1309, 2008.

HANAHAN, D.; WEINBERG, R. A. Hallmarks of cancer: the next generation. Cell, v. 144, n. 5, p. 646-674, 2011.

HAYES, A.; ADAMS, V.; SMITH, K.; MAGLENNON, G.; MURPHY, S. Vinblastine and prednisolone chemotherapy for surgically excised grade III canine cutaneous mast cell tumours. Veterinary and Comparative Oncology, v. 5, n. 3, p; 168-176, 2007.

HERRING, E. S. I.; SMITH, M. M.; ROBERTSON, J. L. Lymph node staging of oral and maxillofacial neoplasms in 31 dogs and cats. Journal of Veterinary Dentistry, v. 19, n. 3, p. 122-126, 2002.

HILLERS, K. R. I.; DERNELL, W. S.; LAFFERTY, M. H.; WITHROW, S. J.; LANA, S. E. Incidence and prognostic importance of lymph node metastasis in dogs with appendicular osteosarcoma: 228 cases (1986-2003). Journal of the Veterinary Medical Association, v. 228, n. 8, p. 1364-1367, 2005. 
HILLMAN, L. A.; GARRET, D. L.; LORIMIER, L. P.; CHARNEY, C. S.; BORST, B. L.; FAN, M. T. Biological behavior of oral and perioral mast cell tumors in dogs: 44 cases (1996-2006). Journal of the American Veterinary Medical Association, v. 237, n. 8, p. 936-942, 2010.

HIRAKAWA, S. From tumor lymphangiogenesis to lymphvascular niche. Cancer Science, v. 100, n. 6, p. 983-989, 2009.

HIRAKAWA, S.; BROWN, F. L.; KODAMA, S.; PAAVONEN, K.; ALITALO, K.; DETMAR, M. VEGF-C-induced lymphangiogenesis in sentinel lymph nodes promotes tumor metastasis to distant sites. Blood, v. 109, n. 3, p. 1010-1017, 2007.

HIRAKAWA, S.; KODAMA, S.; KUNSTFELD, R.; KAJIYA, K.; BROWN, F. L.; DETMAR, M. VEGF-A induces tumor and sentinel lymph node lymphangiogenesis and promotes lymphatic metastasis. The Journal of Experimental Medicine, v. 201, n. 7, p. 1089-1099, 2005.

HOTTENDORF, G. H.; NIELSEN, S. W. Pathologic report of 29 necropsies on dogs with mastocytoma. Pathology Veterinary, v. 5, p. 102-121, 1968.

HOWARD, E. B.; SAWA, T. R.; NIELSEN, S. W.; KENYON, A. J. Mastocytoma and gastroduodenal ulceration. Gastric and duodenal ulcers in dogs with mastocytoma. Pathologia Veterinaria, v. 6, n. 2, p. 146-158, 1969.

HUME, C. T.; KIUPEL, M.; RIGATTI, L.; SHOFER, F. S.; SKORUPSKI, K. A.; SORENMO, K. U. Outcomes of dogs with grade 3 mast cell tumors: 43 cases (19972007). Journal of the American Animal Hospital Association, v. 47, p. 37-44, 2011.

ISOTANI, M.; ISHIDA, N.; TOMINAGA, M.; TAMURA, K.; YAGIHARA, H.; OCHI, S.; KATO, R.; KOBAYASHI, T.; FUJITA, M.; FUJINO, Y.; SETOGUCHI, A.; ONO, K.; WASHIZU, T.; BONKOBARA, M. Effect of tyrosine kinase inhibition by imatinib mesylate on mast cell tumors in dogs. Journal of Veterinary Internal Medicine, $v$. 22, n. 4, p. 985-988, 2008.

JAFFE, M. H.; HOSGOOD, G.; TAYLOR, H. W.; KERWIN, S. C.; HEDLUND, C. S.; LOPEZ, M. K.; DAVIDSON, J. R.; MILLER, D. M.; PARANJPE, M. Immunohistochemical and clinical evaluation of p53 in canine cutaneous mast cell tumors. Veterinary Pathology, v. 37, n. 1, p. 40-46, 2000. 
JAWAD, H.; SIRAJUDDIN, A.; CHUNG, J. H. Review of the International Association for the Study of Lung Cancer Lymph Node Classification System. Localization of Lymph Node Stations on CT Imaging. Clinics in Chest Medicine, v. 34, n. 3, p 353363, 2013.

KANG, S.; YOO, H. J.; HWANG, J. H.; LIM, M. C.; SEO, S. S.; PARK, S. Y. Sentinel lymph node biopsy in endometrial cancer: meta-analysis of 26 studies. Gynecologic Oncology, v. 123, n. 3, p. 522-527, 2011.

KARPANEN, T.; EGEBLAD, M.; KARKKAINEN, M. J.; KUBO, H.; YIA-HERTTUALA, S.; JAATTELA, M.; ALITALO, K. Vascular endothelial growth factor C promotes tumor lymphangiogenesis and intralymphatic tumor growth. Cancer Research, v. 61, p. 1786-1790, 2001.

KIERSZENBAUM, A. L. Tecidos conjuntivos. In: celular. 2. ed. Rio de Janeiro: Elsevier, 2008. cap. 4, p. 109-144. . Histologia e biologia

\author{
celular. 2. ed. Rio de Janeiro: Elsevier, 2008. cap. 4, p. 109-144.
}

KIM, R.; MANABU, E.; KAZUAKI, T.; KOJI, A. Immunobiology of the sentinel lymph node and its potential role for antitumour immunity. Lancet Oncology, v 7, p. 10061016, 2006.

KIMURA, K.C.; GÁRATE, A. P.; DAGLI, M.L. Retrospective study of neoplasms in domestic animals: a survey the Service of Animal Pathology, Department of Pathology, School of Veterinary Medicine and Animal Science, Southeast Brazil. Brazilian Journal of Veterinary Pathology, v. 5, p. 60-69, 2012.

KIRPENSTEIJN, J.; KIK, M.; RUTTEMAN, G. R.; TESKE, E. Prognostic significance of a new histologic grading system for canine osteosarcoma. Veterinary Pathology, v. 39, p. 240-246, 2002.

KIUPEL, M.; WEBSTER, J. D.; BAILEY, K. L.; BEST, S.; DELAY, J.; DETRISAC, C. J.; FITZGERALD, S. D.; GAMBLE, D.; GINN, P. E.; GOLDSCHMIDT, M. H.; HENDRICK, M. J.; HOWERTH, E. W.; JANOVITZ, E. B.; LANGOHR, I.; LENZ, S. D.; LIPSCOMB, T. P.; MILLER, M. A.; MISDORP, W.; MOROFF, S.; MULLANEY, T. P.; NEYENS, I.; O'TOOLE, D.; RAMOS-VARA, J.; SCASE, T. J.; SCHULMAN, F. Y.; SLEDGE, S.; SMEDLEY, R. C.; SMITH, K.; SNYDER, P. W.; SOUTHORN, E.; STEDMAN, N. L.; STEFICEK, B. A.; STROMBERG, P. C.; VALLI, V. E.; WEISBRODE, S. E.; YAGER, J.; HELLER, J.; MILLER, R. Proposal of a 2-tier histologic grading system for canine cutaneous mast cell tumors to more accurately predict biological behavior. Veterinary pathology, v. 48, n. 1, p. 147-155, 2011. 
KIUPEL, M.; WEBSTER, J. D.; KANEENE, J. B.; MILLER, R.; YUZBASIYANGURKAN, V. The use of KIT and tryptase expression patterns as prognostic tools for canine cutaneous mast cell tumors. Veterinary Pathology, v. 41, n. 4, p. 371-377, 2004.

KIUPEL, M.; WEBSTER, D. J.; MILLER, R. A.; KANEENE, J. B. Impact of tumour depth, tumour location and multiple synchronous masses on the prognosis of canine cutaneous mast cell tumours. Journal of Veterinary Internal Medicine. A,

Physiology, Pathology, Clinical Medicine, v. 52, p. 280-286, 2005.

KLOPFLEISCH, R.; GRUBER, A. D. Increased expression of BRCA2 and RAD51 in lymph node metastases of canine mammary adenocarcinomas. Veterinary pathology, v. 46, n. 3, p. 416-422, maio 2009.

KRICK, E. L.; BILLINGS, A. P.; SHOFER, F. S.; WATANABE, S.; SORENMO, K. U. Cytological lymph node evaluation in dogs with mast cell tumours: association with grade and survival. Veterinary and Comparative Oncology, v. 7, n. 2, p. 130-138, 2009.

KRISHNASWANY, G.; AJITAWI, O.; CHI, D. S. The human mast cell: an overview. Methods in Molecular Biology, v. 315, p. 13-34, 2006.

KROKOWSKI, M.; SOTLAR, K.; KRAUTH, M. T.; FOFINGER, M.; VALENT, P.; HORNY, H. P. Deliation of patterns of bone marrow mast cell infiltration in systemic mastocytosis: value of CD25, correlation with subvariantes of the disease and separation from mast cell hyperplasia. American Journal of Clinical Pathology, v. 124, p. 560-568, 2005.

LaDUE, T.; PRICE, G. S.; DODGE, R.; PAGE, R. L.; THRALL, D. E. Radiation therapy for incompletely resected canine mast cell tumors. Veterinary Radiology and Ultrasound, v. 39, p. 57-62, 1998.

LANGENBACH, A.; MCMANUS, P. M.; HENDRICK, M. J.; SHOFER, F. S.; SORENMO, K. U. Sensitivity and specificity of methods of assessing the regional lymph nodes for evidence of metastasis in dogs and cats with solid tumors. Journal of the American Veterinary Medical Association, v. 218, n. 9, p. 1424-1428, 2001.

LAVAlLE, G. E.; ARAUjO, R. B.; CARNEIRO, R. A.; PEREIRA, L. C. Punção aspirativa por agulha fina para diagnóstico de mastocitoma em cães. Arquivo Brasileiro de Medicina Veterinária e Zootecnia, v. 55, n. 4, p. 10-13, 2003. 
LEMARIE, R. J.; LEMARIE, S. L.; HEDLUNG, C. S. Mast cell tumors: clinical management. Compendium on Continuing Education for the Practising Veterinarian, v. 17, n. 9, p. 1085-1101, 1995.

LETARD, S.; YAN, Y.; HANSSENS, K.; PALMERINI, F.; LEVENTHAL, S. P.; GUERY, S.; MOUSSY, A.; KINET, J.; HERMINE, O.; DUBREUIL, P. Gain-of-function mutations in the extracellular domain of KIT are common in canine mast cell tumors.

Molecular Cancer Research : MCR, v. 6, n. 7, p. 1137-1145, 2008.

LETORNEAU, S.; KRIEG, C.; PANTALEAO, G.; BOYMAN, O. IL-2 and CD25dependent immunoregulatory mechanisms in the homeostasis of T-cell subsets. Journal of Allergy and Clinical Immunology, v. 123, n. 4, p. 758-762, 2009.

LI DESTRI, G.; DI CARLO, I.; SCILLETTA, R.; SCILLETTA, B.; PULEO, S. Colorectal cancer and lymph nodes: The obsession with the number 12. World Journal of Gastroenterology, v. 20, n. 8, p. 1951-1960, 2014.

LIAO, L.-J.; WU-CHIA, L.; WAN-LU, H.; CHI-TE, W.; MEI-SHU, L. Detection of cervical lymph node metastasis in head and neck cancer patients with clinically NO neck-a meta-analysis comparing different imaging modalities. BMC Cancer, v. 12, n. 1, p. 236, 2012.

LONDON, C.; GALLI, S. J.; YUUKI, T.; HU, Z.; HELFAND, S. C.; GEISSLER, E. N. Spontaneous canine mast cell tumors express tandem duplications in the protooncogene c-kit. Experimental Hemathology, v. 27, p. 589-597, 1999.

LONDON, C.; SEGUIN, B. Mast cell tumors in the dog. Veterinary Clinics of Nort America: Small Animal Practice, v. 33, p. 473-489, 2003.

LONDON, C. A.; MALPAS, B. P.; WOOD-FOLLIS, S. L.; BOUCHER, F. J.; RUSK, W. A.; ROSENBERG, P. M.; HENRY, J. C.; MITCHENER, L.; KLEIN, K. M.; HINTERMEISTER, G. J.; BERGMAN, J. P.; COUTO, C. G.; MAULDIN, N. G.; MICHELS, M. G. Multi-center, placebo-controlled, double-blind, randomized study of oral toceranib phosphate (SU11654), a receptor tyrosine kinase inhibitor, for the treatment of dogs with recurrent (either local or distant) mast cell tumor following surgical excision. Clinical Cancer Research, v. 15, n. 11, p. 3856-3865, 2009.

LYMAN, G. H.; GIULIANO, A. E.; SOMERFIELD, M. R.; BENSON, A. B.; BODURKA, D. C.; BURSTEIN, H. J.; COCHRAN, A. J.; CODY, H. S.; EDGE, S. B.; GALPER, S.; HAYMAN, J. A.; KIM, T. Y.; PERKINS, C. L.; PODOLOFF, D. A.; SIVASUBRAMANIAM, V. H.; TURNER, R. R.; WAHL, R.; WEAVER, D. L.; WOLFF, A. C.; WINER, E. P. American society of clinical oncology guideline 
recommendations for sentinel lymph node biopsy in early-stage breast cancer. Journal of Clinical Oncology, v. 23, n. 30, p. 7703-7720, 2005.

MA, Y.; LONGLEY, B. J.; WANG, X.; BLOUNT, L. J.; LANGLEY, K.; CAUGHEY, G. $\mathrm{H}$. Clustering of activating mutations in c-kit's juxtamembrane coding region in canine mast cell neoplasms. Journal of Investigative Dermatology, v. 112, p. 165-170, 1999.

MACKOWIAK, I. I.; GENTILE, L. B.; CHAIBLE, L. M.; NAGAMINE, M. K.; GUERRA, J. M.; MOTA, F. F.; MATERA, J. M.; MENNECIER, G.; SANCHES, D. S.; DAGLI, M. L. Z. E-cadherin in canine mast cell tumors: decreased expression and altered subcellular localization in Grade 3 tumors. Veterinary Journal, v. 194, n. 3, p. 405411, 2012.

MACNEIL, A. L. Cytology of canine and feline cutaneous and subcutaneous lesions and lymph nodes. Topics in Companion Animal Medicine, v. 26, n. 2, p. 62-76, 2011.

MACY, D. W. Canine mast cell tumors. Veterinary Clinics of North America Small Animal Practice, v. 15, n. 4, p. 783-803, 1985.

MACY, D. W. Canine and feline mast cell tumors: biologic behavior, diagnosis, and therapy. Seminars in Veterinary Medicine and Surgery, v. 1, n. 1, p. 72-83, 1986.

MAHLER, S. Mast cell tumor in a young boxer. Veterinary Record, v. 18, p.182, 2012.

MALEK, T. R. The biology of interleukin-2. Annual Review of Immunology, v. 26, p. 543-479, 2008.

MANDRIOTA, S. J.; JUSSILA, L.; JELTSCH, M.; COMPAGNI, A.; BAETENS, D.; PREVO, R.; BANERJI, S.; HUARTE, J.; MONTESANO, R.; JACKSON, D. G.; ORCI, L.; ALITALO, K.; CHRISTOFORI, G.; PEPPER, M. S. Vascular endothelial growth factor-C-mediated lymphangiogenesis promotes tumour metastasis. European Molecular Biology Oncology Journal, v. 20, n. 4, p. 672-682, 2001.

MARCONATO, L.; GIULIANO, B.; GIORGIO, R.; CESARI, A.; ZATELLI, A.; ZINI, E. Clinicopathological features and outcome for dogs with mast cell tumors and bone marrow involvement. Journal of Veterinary Internal Medicine, v. 22, n. 4, p. 10011007, 2008a. 
MARCONATO, L.; MARCHETTI, V.; FRANCIONE, D.; MASSERDOTTI, C.; GREGORI, R.; LEOTTA, R.;ABRAMO, F. Morphometrical approach for predicting regional lymph node micrometastatic load in canine mast cell tumours: Preliminary results. Veterinary and Comparative Oncology, v. 6, n. 3, p. 162-170, 2008b.

MARCONATO, L.; ZORZAN, E.; GIANTIN, M.; DI PALMA, S.; DACASTO, M. Concordance of c-kit mutational status in matched primary and metastatic cutaneous canine mast cell tumors at baseline. Journal of Veterinary Internal Medicine, v. 28, p. 547-553, 2014.

MARTIN, P. D.; ARGYLE, D. J. Advances in the management of skin cancer. Veterinary Dermatology, v. 24, n. 1, p. 173-180, 2013.

MCCAW, D. L.; MILLER, M. A.; BERGMAN, P. J.; WITHROW, S. J.; MOORE, A. S.; KNAPP, D. W.; FOWLER, D.; JOHNSON, J. C. Vincristine therapy for mast cell tumors in dogs. Journal of Veterinary Internal Medicine, v. 11, n. 6, p. 375-378, 1997.

MCCAW, D. L.; MILLER, M. A.; OLGIVIE, G. K.; WITHROW, S. J.; BREWER, W. G. J.; KLEIN, M. K.; BELL, F. W.; ANDERSON, S . K. Responde of canine mast cell tumors to treatment with oral prednisone. Journal of Veterinary Internal Medicine, v. 8, n. 6, p. 406-408, 1994.

MCMANUS, P. M. Frequency and severity of mastocytemia in dogs with and without mast cell tumors: 120 cases (1995-1997). Journal of the American Veterinary Medical Association, v. 215, p. 355-357, 1999.

MCNIEL, E. A.; OGILVIE, G. K.; POWERS, B. E.; HUTCHISON, J. M; SALMAN, M. D.; WITHROW, S. J. Evaluation of prognostic factors for dogs with primary lung tumors: 67 cases (1985-1992). Journal of the American Veterinary Medical Association, v. 211, n. 11, p. 1422-1427, 1997.

MCNIEL, E. A.; PRINK, A. L.; O'BRIEN, T. D. Evaluation of risk and clinical outcome os mast cell tumors in pug dogs. Veterinary and Comparative Oncology, v. 4, n. 1, p. 2-8, 2006.

MEININGER, C. J.; YANO, H.; ROTTAPEL, R.; BERNSTEIN, A.; ZSEBO, K. M.; ZETTER, B. R. The c-kit receptor ligand functions as a mast cell chemoattractant. Blood, v. 79, p. 958-963, 1992. 
MERIC, F.; MIRZA, N. Q.; BUZDAR, A. U.; HUNT, K. K.; AMES, F. C.; ROSS, M. I.; POLLOCK, R. E.; NEWMAN, L. A.; FEIG, B. W.; STROM, E. A.; BUCHHOLZ, T. A.; MCNEESE, M. D.; HORTOBAGYI, G. N.; DINGLETARY, E. Prognostic implications of pathological lymph node status after preoperative chemotherapy for operable T3N0M0 breast cancer. Annals of Surgical Oncology, v. 7, n. 6, p. 435-440, 2000.

MEYER, A.; GRUBER, A. D.; KLOPFLEISCH, R. CD25 is expressed by canine cutaneous mast cell tumors but not by cutaneous connective tissue mast cells.

Veterinary Pathology, v. 49, n. 6. p. 988-997, 2012.

MILLER, D. M. The ocurrence of mast cell tumors in the dog. Veterinary Clinics of North America: Small Animal Practice, v. 33, p. 473-489, 1995.

MILLS, J. N. Lymph node cytology. Veterinary Clinics of North America: Small Animal Practice, v. 19, n. 4, 1989.

MISDORP, W. Mast cells and canine mast cell tumors: a review. Veterinary Quarterly, v. 26, p. 156-169, 2004.

MORTON, D. L.; WEN, D. R.; WONG, J. H. Technical details of intraoperative pymphatic mapping for early stage melanoma. Archives of Surgery, v. 127, p. 392399, 1992.

MULLINS, M. N.; DERNELL, W. S.; WITHROW, S. J.; EHRHART, E. J.; THAMM, D. H.; LANA, S. E. Evaluation of prognostic factors associated with outcome in dogs with multiple cutaneous mast cell tumors treated with surgery with and without adjuvant treatment: 54 cases (1998-2004). Journal of the American Veterinary Medical Association, v. 228, n. 1, p. 91-95, 2006.

MURAMOTO, C.; STERMAN, F. A.; HAGEN, C. S. F.; FONSECA-PINTO, A. C. B. C.; OLIVEIRA, C. M.; FAUSTINO, M.; TALIB, M. S. F.; TORRES, L. N. Avaliação ulrassonográfica de linfonodos na pesquisa de metástases de neoplasia mamária em cadelas. Pesquisa Veterinária Brasileira, v. 31, n. 11, p. 1006-1013, 2011.

MURPHY, S.; SPARKES, A. H.; BLUNDEN, A. S; BREARLEY, M. J.; SMITH, K. C. Effects of stage and number of tumors on prognosis of dogs with cutaneous mast cell tumors. Veterinary Record, v. 158, p. 287-297, 2006.

MURPHY, S.; SPARKES, A. H.; BREARLEY, M. J.; SMITH, K. C.; BLUNDEN, A. S. Relationships between the histological grade of cutaneous mast cell tumors in dogs, 
their survival and the efficacy of surgycal resection. Veterinary Record, v. 154, p. 743-746, 2004.

NEWMAN, S. J.; MRKONJICH, L.; WALKER, K. K.; ROHRBACH, B. W. Canine subcutaneous mast cell tumor: diagnosis and prognosis. Journal of Comparative Pathology, v. 136, p. 231-239, 2007.

NEYENS, I. J.; KIRPENSTEIJN, J.; GRINWIS, G. C.; TESKE, E. Pilot study of intraregional deionised water adjunct therapy for mast cell tumours in dogs. The Veterinary Record, v. 154, p. 90-91, 2004.

NG, K.; MEYERHARDT, J. A.; WU, K.; FESKANICH, D.; HOLLIS, B. W.; GIOVANUCCI, E. L.; FUCHS, C. S. Circulating 25-hydroxyvitamin D levels and survival in patients with colorectal cancer. Journal of Clinical Oncology, v. 26, p. 2984-2991, 2008.

NORTHRUP, N. C.; HOWERTH, E. W.; HARMON, B. G.; BROWN, C. A.; CARMICHEAL, K. P.; GARCIA, A. P.; LATIMER, K. S.; MUNDAY, J. S.; RAKISH, P. M.; RICHEY, L. J.; STEDMAN, N. L.; GIEGER, T. L. Variation among pathologists in the histologic grading of canine cutaneous mast cell tumors with uniform use of a single grading reference. Journal of Veterinary Diagnostic Investigation, v. 17, n. 6 , p. 561-564, 2005.

NYMAN, H. T.; KRISTENSEN, A. T.; SKOYGAARD, I. M.; MCEVOY, F. J. Characterization of normal and abnormal canine superficial lymph nodes using grayscale B-mode, color flow mapping, power and superficial Doppler ultrasonographu: a multivariate study. Veterinary Radiology and Ultrasound, v. 46, n. 5, p. 404-410, 2005.

O'CONNELL, K.; THOMSON, M. Evaluation of prognostic indicators in dogs with multiple, simultaneously occurring cutaneous mast cell tumours: 63 cases.

Veterinary and Comparative Oncology, v. 11, n. 1, p. 51-62, 2013.

O'KEEFE, D. A. Canine mast cell tumors. The Veterinary Clinics of North America. Small Animal Practice, v. 20, n. 4, p. 1105-1115, 1990.

OZAKI, K.; YAMAGAMI, T.; NOMURA, K.; NARAMA, I. Prognostic significance of surgical margin, Ki-67 and cyclin D1 protein expression in grade II canine cutaneous mast cell tumor. Journal of Veterinary Medical Science, v. 69, n. 11, p. 1117$1121,2007$. 
PAGET, S. The distribution of secondary growths in cancer of the breast. Lancet, v. 133, p. 571-573, 1889.

PASSANTINO, L.; PASSANTINO, G.; CIANCIOTTA, A.; RIBAUD, M. R.; LO PRESTI, G.; RANIERI, G.; PERILLO, A. Expression of proto-oncogene C-kit and correlation with morphological evaluations in canine cutaneous mast cell tumors. Immunopharmacology and Immunotoxicology, v. 30, n. 3, p. 609-621, 2008.

PATNAIK, A. K.; EHLER, W. J.; MACEWEN, E. G. Canine cutaneous mast cell tumor: morphologic grading and survival time in 83 dogs. Veterinary Pathology, v. 21, n. 5, p. 469-474, 1984.

PATSIKAS, M. N.; KARAYANNOPOULOU, M.; KALDRYMIDOY, E.; PAPAZOGLOU, L. G.; PAPADOPOULOU, P. L.; TZEGAS, S. I.; TZIRIS, N. E.; KAITZIS, D. G.; DIMITRIADIS, A. S.; DESSIRIS, A. K. The lymph drainage of the neoplastic mammary glands in the bitch: a lymphographic study. Anatomia, Histologia, Embryologia, v. 35, p. 228-234, 2006.

PEREIRA, C. T.; RAHAL, S. C.; BALIEIRO, J. C.; RIBEIRO, A. A. C. M. Lymphatic drainage on healthy and neoplastic mammary glands in female dogs: can it really be altered? Anatomia, Histologia, Embryologia, v. 32, p. 282-290, 2003.

PEREIRA, C. T.; MARQUES, F. L. N.; WILLIAMS, J.; MARTIN, B. W.; BOMBONATO, P. P. TC-99M-labeled dextran for mammary lymphoscintigraphy in dogs. Veterinary Radiology and Ultrasound, v. 49, n. 5, p. 487-497, 2008.

PINHEIRO, L. G. P.; MORAES, M. O.; SOARES, A. H.; LOPES, A. J. T.; NAGUERE, M. A. S. P.; GONDIM, F. A. L.; BRANDAO, C. B.; NASCIMENTO, D. C. H. Estudo experimental de linfonodo sentinela na mama da cadela com azul patente $\mathrm{e}$ Tecnécio Tc99m. Acta Cirúrgica Brasileira, v. 18, n. 3, p. 514-517, 2003.

POKORNY, E.; HECHT S.; SURA, P. A.; LEBLANC, A. K.; PHILLIPS, J.; CONKLIN, G. A.; HAIFLEY, K. A.; NEWKIRK, K. Magnetic resonance imaging of canine mast cell tumors. Veterinary Radiology \& Ultrasound, v. 53, n. 2, p. 167-173, 2012.

POLTON, G. A.; BREARLEY, M. J.; GREEN, L. M.; SCASE, T. J. Expression of Ecadherin in canine anal sac gland carcinoma and its association with survival.

Veterinary and Comparative Oncology, v. 5, p. 232-238, 2007.

POIRIER, V. J.; ADAMS, W. A.; FORREST, L. J.; GREEN, E. M.; DUBIELZIG, R. R.; VAIL, D. M. Radiation therapy for incompletely excised grade II canine mast cell 
tumors. Journal of the American Animal Hospital Association, v. 42, n. 6, p. 430434, 2006.

PREZIOSI, R.; MORINI, M.; SARLI, G. Expression of the KIT protein (CD117) in primary cutaneous mast cell tumors of the dog. Journal of Veterinary Diagnostic Investigation, v. 16, n. 6, p. 554-561, 2004a.

PREZIOSI, R.; SARLI, G.; PALTRINIERI, M. Multivariate survival analysis of histological parameters and clinical presentation in canine cutaneous mast cell tumors. Veterinay Research Communications, v. 31, p. 287-296, 2007.

PREZIOSI, R.; SARLI, G.; PALTRINIERI, M. Prognostic value of intratumoral vessel density in cutaneous mast cell tumor of the dog. Journal of Comparative Pathology, v. 130, n. 2-3, p. 143-151, 2004b.

PRYER, N. K.; LEE, L. B.; ZADOVASKAYA, R.; YU, X.; SUKBUNTHERNG, J.; CHERRINGTON, J. M.; LONDON, C. A. Proof of Target for SU11654: inhibition of KIT phosphorylation in canine mast cell tumors. Clinical Cancer Research, v. 9, n. 15, p. 5729-5734, 2003.

PURDIE, C. A. Sentinel lymph node biopsy: review of the literature and guidelines for pathological handling and reporting. Current Diagnostic Pathology, v. 13, n. 2, p. 106-115, 2007.

QIU, C.; LIN, D. D.; WANG, H. H.; QIAO, C. H.; WANG, J.; ZHANG, T. Quantification of VEGF-C expression in canine mammary tumors. Australian Veterinary Journal, v. 86, p. $279-282,2008$.

QUINN, C. M.; WRIGTH, N. A. The clinical assessment of proliferation and growth in human tumors: evaluation of methods and application as a prognostic variable. Journal of Pathology, v. 160, n. 2, p. 93-102, 1990.

RAHARISON, F.; MOGICATO, G.; SAUTET, J. Le système lymphatique des glandes mammaires de la chatte. Proposition de schèmas d'exérèse chirurgicale en cas de tumeurs mammaires. Revue de Medecine Veterinaire, v. 160, n. 12, p. 562-568, 2009.

RASKIN, R. E. Lymphoid system. In: RASKIN, R. E.; MEYER, D. J. Atlas of canine and feline cytology. Philadelphia: WB Saunders, 2001. cap. 7, p. 95-97. 
RASSNICK, K. M.; BAILEY, D. B.; FLORY, A. B.; BALKMAN, C. E.; KISELOW, M. A.; INTILE, J. L.; AUTIO, K. Efficacy of vinblastine for treatment of canine mast cell tumors. Journal of Veterinary Internal Medicine, v. 22, n. 6, p. 1390-1396, 2008.

REGUERA, M. J.; FERRER, L.; RABANAL, R. M. Evaluation of na intron deletion in the c-kit gene of canine mast cell tumors. American Journal of Veterinary Research, v. 63, p. 1257-1261, 2002.

REGUERA, M. J.; RABANAL, R. M.; PUIGDEMONT, A.; FERRER, L.Canine mast cell tumors express stem cell factor receptor. American Journal of Dermatopathology, v. 22, p. 49-54, 2000.

ROBAT, C.; LONDON, C. A.; BUNTING, L., MCCARTAN, L.; STINGLE, N.; SELTING, K.; KURZMAN, I.; VAIL, D. M. Safety evaluation of combination vinblastine and toceranib phosphate (Palladia $\AA$ ) in dogs: A phase I dose-finding study. Veterinary and Comparative Oncology, v. 10, n. 3, p. 174-183, 2012.

ROGERS, K. S. Common questions about diagnosing and treating canine mast cell tumors. Veterinary Medicine, v. 88, p. 46-250, 1993.

ROGERS, K. S. Mast cell tumors. Veterinary Clinics of North America: Small Animal Practice, v. 26, p. 87-101, 1996.

ROMANSIK, E. M.; REILLY, C. M.; KASS, P. H.; MOORE, P. F.; LONDON, C. A. Mitotic index is predictive for survival for canine cutaneous mast cell tumors.

Veterinary Pathology, v. 44, n. 3, p. 335-341, 2007.

ROTHWELL, T. L.; HOWLETT, C. R.; MIDDLETON, D. J.; GRIFFITHS, D. A.; DUFF, B. C. Skin neoplasms of dogs in Sydney. Australian Veterinary Journal, v. 64, n. 6, p. $161-164,1987$.

ROTTEM, M.; KIRSHENBAUM, A. S.; METCALFE, D. D. Early development of mast cells. International Archives of Allergy and Applied Immunology, v. 94, n. 1-4, p. 104-109, 1991.

SABATTINI, S.; BETTINI, G. Prognostic value of histologic and immunohistochemical features in feline cutaneous mast cell tumors. Veterinary Pathology, v. 47, n. 4, p. 643-653, 2010.

SABATTINI, S.; SCARPA, F.; BERLATO, D.; BETTINI, G. Histologic grading of canine mast cell tumor: is 2 better than 3?. Veterinary Pathology, fev, 2014. 
SAMUELSON, D. A. Connective tissue. In: Textbook of veterinary histology. St. Louis: Saunders Elsevier, 2007. cap. 5, p. 72-99.

SEGUIN, B.; BESANCON, M. F.; MCCALLAN, J. L.; DEWE, L. L.; TENWOLDE, M. C.; WONG, E. K.; KENT, M. S. Recurrence rate, clinical outcome and cellular proliferation indices as prognostic indicators after incomplete surgical excision of cutaneous grade II mast cell tumors: 28 dogs (1994-2002). Journal of Veterinary Internal Medicine, v. 20, p. 933-940, 2006.

SCHMOLZE, D.; AWTREY, C. S.; HECHT, J. L. Value of additional level sections in the evaluation of lymph nodes for endometrial carcinoma staging. American Journal of Clinical Pathology, v. 140, n. 4, p. 516-518, out. 2013.

SCHULTEISS, P. C.; GARDINER, D. W.; RAO, S.; OLEA-POPELKA, F.; TUOHY, J. L. Association os histologic tumor characteristics and size of surgical margins with clinical outcome after surgical removal of cutaneous mast cell tumors in dogs.

Journal of the American Veterinary Medical Association, v. 238, p. 1464-1469, 2011.

SÉGUIN, B.; LEIBMAN, N. F.; BREGAZZI, V. S.; OGILVIE, G. K.; POWERS, B. E.; DERNELL, W. S.; FETTMAN, M. J.; WITHROW, S. J. Clinical outcome of dogs with grade-II mast cell tumors treated with surgery alone: 55 cases (1996-1999). Journal of the American Veterinary Medical Association, v. 218, n. 7, p. 1120-1123, 2001.

SFILIGOI, G.; RASSNICK, K. M.; SCARLETT, J. M.; NORTHRUP, N. C.; GIEGER, T. L. Outcome of dogs with mast cell tumors in the inguinal or perineal region versus other cutaneous locations: 124 caes (1990-2001). Journal of the American Veterinary Medical Association, v. 226, p. 1368-1374, 2005.

SHENDURE, J.; JI, H. Next-generation DNA sequencing. Nature Biotechnology, v. 26, n. 10, p. 1135-1145, 2008.

SHIBUYA, M. Tyrosine kinase receptor Flt/VEGFR family: its characterization related to angiogenesis and cancer. Genes \& Cancer, v. 1, n. 11, p. 1119-1123, 2010.

SIMEONOV, R.; SIMEONOVA, G. Quantitative analysis in canine cutaneous mast cell tumors. Analytical and Quantitative Cytology and Histology, v. 32, n. 3, p. 178-181, 2010. 
SIMOES, J. P.; SCHONING, P. Canine mast cell tumors: a comparison of staining techniques. Journal of Veterinary Diagnostic Investigation, v. 6, n. 4, p. 458-465, 1994.

SIMOES, J. P. C.; SCHONING, P.; BUTINE, M. Prognosis of canine mast cell tumors: a comparison of three methods. Veterinary Pathology, v. 31, n. 6, p. 637647, 1994.

SKOBE, M.; HAWIGHORST , T.; JACKSON, D. G.; PREVO, R.; JANES, L.; VELASCO, P.; RICCARDI, L.; ALITALO, K.; CLAFFEY, K.; DETMAR, M. Induction of tumor lymphangiogenesis by VEGF-C promotes breast cancer metastasis. Nature Medicine, v. 7, n. 2, p. 192-198, 2001.

SLEECKX, N.; VAN BRANTEGEN, L.; FRANCEN, E.; VAN DEN EYNDEN, G.; CASTELEYN, C.; VELDHUIS KROEZE, E.; VAN GINNEKEN, C. Evaluation of immunohistochemical markers of lymphatic and blood vessels in canine mammary tumours. Journal of Comparative Pathology, v. 148, n. 4, p. 307-317, 2013.

SLEECKX, N.; VAN BRANTEGEN, L.; VAN DEN EYNDEN, G.; FRANCEN, E.; CASTELEYN, C.; VAN CRUCHTEN, S.; VELDHUIS KROEZE, E.; VAN GINNEKEN, C. Lymphangiogenesis in canine mammary tumours: A morphometric and prognostic study. Journal of Comparative Pathology, v. 150, n. 2-3, p. 184-193, 2014.

STACKER, S. A.; CAESAR, C.; BALDWIN, M. E.; THORNTON, G. E.; WILLIAMS, R. A.; PREVO, R.; JACKSON, D. G.; NISHIKAWA, S.; KUBO, H.; ACHEN, M. G. VEGF$D$ promotes the metastatic spread of tumor cells via the lymphatics. Nature Medicine, v. 7, n. 2, p. 186-191, 2001.

STANCLIFT, R. M.; GILSON, S. D. Evaluation of neoadjuvant prednisone administration and surgical excision in treatment of cutaneous mast cell tumors in dogs. Journal of the American Veterinary Medical Association, v. 232, n. 1, p. 53-62, 2008.

STOCKHAM, S. L.; BASEL, D. L.; SCHIMIDT, D. A. Mastocytemis in dogs with acute inflammatory diseases. Veterinary Clinical Pathology, v. 15, p. 16-21, 1986.

STREFEZZI, D. R. F.; KLEEB, S. R.; XAVIER, J. G.; CATÃO-DIAS, J. L. Avaliação da proliferação celular como indicador prognóstico para mastocitomas cutaneos caninos. Pesquisa Veterinária Brasileira, v. 30, n. 7, p. 559-656, 2010. 
STREFEZZI, D. R. F.; KLEEB, S. R.; XAVIER, J. G.; FUKUMASU, H.; CATÃO-DIAS, J. L. The Value of immunohistochemical expression of BAX in formulating a prognosis for canine cutaneous mast cell tumours. Journal of Comparative Pathology, v. 146, n. 4, p. 314-319, 2012.

STREFEZZI, R. D. F.; XAVIER, J. G.; CATÃO-DIAS, J. L. Morphometry of canine cutaneous mast cell tumors. Veterinary Pathology, v. 40, n. 3, p. 268-275, 2003.

STREFEZZI, D. R. F.; XAVIER, J. G.; KLEEB, S. R.; CATÃO-DIAS, J. L. Nuclear morphometry in cytopathology: a prognostic indicator for canine cutaneous mast cell tumors. Journal of Veterinary Diagnostic Investigation, v. 21, n. 6, p. 821-825, 2009.

SWARTE, M.; ALEXANDRE, K.; RANNOU, B.; D'ANJOU, A.; BLOND, L.; BEAUCHAMP, G. Comparison of sonographic features og benign and neoplastic deep lymph nodes in dogs. Veteranary Radiology \& Ultrasound, v. 52, n. 4, p. 451456, 2011.

SZCZUBIAL, M.; LOPUSZYNSKI, W. Prognostic value of regional lymph node status in canine mammary carcinomas. Veterinary and Comparative Oncology, v. 9, n. 4, p. 296-303, 2011.

TAKAHASHI, T.; KADOSAWA, T.; NAGASE, M.; SASAKI, N. Visceral mast cell tumors in dogs: 10 cases (1982-1997). Journal of the American Veterinary Medical Association, v. 216, n. 2, p. 222-226, 2000.

TAKEUCHI, Y.; FUJINO, Y.; WATANABE, M.; NAKAGAWA, T.; OHNO, K.; SASAKI, N.; SUGANO, S.; TSUJIMOTO, H. Aberrant autophosphorylation of c-Kit receptor in canine mast cell tumor cell lines. Veterinary Immunology and Immunopathology, v. 137, n. 3-4, p. 208-216, 2010.

TAKEUCHI, Y.; FUJINO, Y.; WATANABE, M.; TAKAHASHI, M.; NAKAGAWA, T.; TAKEUCHI, A.; BONKOBARA, M.; KOBAYASHI, T.; OHNO, K.; UCHIDA, K.; ASANO, K.; NISHIMURA, R.; NAKAYAMA, H.; SUGANO, S.; OHASHI, Y.; TSUJIMOTO, H.. Validation of the prognostic value of histopathological grading or Ckit mutation in canine cutaneous mast cell tumours: A retrospective cohort study. Veterinary Journal, v. 196, n. 3, p. 492-498, 2013.

TETĖ, S.; TRIPODI, D.; ROSATI, M.; CONTI, F.; MACCAURO, G.; SAGGNI, A.; SALINI, V.; CIANCHETTI, E.; CARAFFA, A.; ANTINOLFI, P.; TONIATO, E.; CASTELANNI, M. L.; PANDOLFI, F.; FRYDAS, S.; CONTI, P.; THEOHARIDES, T. $C$. Role of mast cells in innate and adaptive immunity. Journal of Biological Regulators and Homeostatic Agents, v. 26, n. 2, p. 193-201, 2012. 
THAMM, D. H.; MAULDIN, E. A.; VAIL, D. M. Prednisone and vinblastine chemotherapy for canine mast cell tumor -41 cases. Journal of Veterinary Internal Medicine, v. 13, p. 491-497, 1999.

THAMM, D. H.; TUREK, M. M.; VAIL, D. M. Outcome and prognostic factors following adjuvant prednisone/vinblastine chemotherapy for high-risk canine mast cell tumour:

61 cases. Journal of Veterinary Medical Science, v. 68, n. 6, p. 581-587, 2006.

THAMM, D. H.; VAIL, D. M. Mast cell tumors. In: WITHROW, S. J.; MACEWEN, S. Small animal clinical oncology. 4. ed. St Louis, MO: Saunders Elsevier, 2007. p. 402-424.

THOMPSON, J. J.; PEARL, D. L.; YAGER, J. A.; BEST, S. J.; COOMBER, B. L.; FOSTER, R. A. Canine subcutaneous mast cell tumor: characterization and prognostic indices. Veterinary Pathology, v. 48, n. 1, p. 156-168, $2011 \mathrm{a}$.

THOMPSON, J. J.; PEARL, D. L.; YAGER, J. A.; BEST, S. J.; COOMBER, B. L.; TORRES, R. N.; KIUPEL, M; FOSTER, R. A. Canine subcutaneous mast cell tumors: cellular proliferation and KIT expression as prognostic indices. Veterinary Pathology, v. 48, n. 1, p. 169-181, 2011b.

THRALL, M. A. Cytology of lymphoid tissue. Compendium on Continuing Education for the Practising Veterinarian, v. 9, n. 2, p. 104-111, 1987.

TRUMP, D. L.; CHADHA, M. K.; SUNGA, A. Y. Vitamin D deficiency and insufficiency among patients with prostate cancer. Brussels Journal of International Studies, v. 104, p. 909-914, 2009.

TUOHY, J. L.; MILGRAM, J.; WORLEY, D. R.; DERNELL, W. S. A review of sentinel lymph node evaluation and the need for its incorporation into veterinary oncology. Veterinary and Comparative Oncology, v. 7, n. 2, p. 81-91, 2009.

TURREL, J. M.; KITCHELL, B. E.; MILLER, L. M.; THEON, A. Prognostic factors for radiation treatment of mast cell tumor in 85 dogs. Journal of the American Veterinary Medical Association, v. 193, p. 935-940, 1988.

VAIL, D. M.; POWERS, B. E.; GETZY, D. M.; MORRISON, W. B.; NORRIS, A. M.; WITHROW, S. J. Evaluation of prognostic factors for dogs with synovial sarcoma: 36 cases (1986-1991). Journal of the American Veterinary Medical Association, v. 205, n. 9, p. 1300-1307, 1994. 
VIALE, G.; MAIORANO, E.; PRUNERI, G.; MASTROPASQUA, M. G.; VALENTINI, S.; GALIMBERTO, V.; ZURRIDA, S.; MAISONNEUVE, P.; PAGANELLI, G.; MAZZAROL, G. Predicting the risk for additional axillary metastases in patients with breast carcinoma and positive sentinel lymph node biopsy. Annals of Surgery, v. 241, n. 2, p. 319-325, 2005.

VICKERY, K. R.; WILSON, H.; VAIL, D. M.; THAMM, D. H. Dose-escalating vinblastine for the treatment of canine mast cell tumors. Veterinary and Comparative Oncology, v. 6, n. 2, p. 111-119, 2008.

VILLAMIL, J. A.; HENRY, C.J.; BRYAN, J. N.; ELLERSIEK, M.; SCHULTZ, L.; TYLER, J. W.; HAHN, A. W. Identification of the most common cutaneous neoplasms in dogs and evaluation of breed and age distribuitions for selected neoplasms. Journal of the American Veterinary Medical Association, v. 239, n. 7, p. 960-965, 2011.

WAKSHLAG, J. J.; RASSNICK, K. M.; MALONE, E. K.; STRUBLE, A. M.; VACHHANI, V.; TRUMP, D. L.; TIAN, L. Cross-sectional study to investigate the association between vitamin $D$ status and cutaneous mas cell tumors in Labrador retrievers. British Journal of Nutrition, v. 106, p. 60-63, 2011.

WALLS, A. F.; JONES, D. B.; WILLIAMS, J. H.; CHURCH, M. K.; HOLGATE, S.T. Immunohistochemical identification of mast cells in formaldehyde-fixed tissue using monoclonal antibodies specific for tryptase. Journal of Pathology, v. 162, p. 119126, 1990.

WANG, X.; APPLE-BY, D-H.; ZHANG, X.; GAN, L.; WANG, J-J.; WAN, F. Comparison of three lymph node staging schemes for predicting outcome in patients with gastric cancer. The British Journal of Surgery, v. 100, n. 4, p. 505-14, 2013.

WARLAND, J.; DOBSON, J. Breed predispositions in canine mast cell tumor: A single centre experience in the United Kingdom. The Veterinary Journal, v. 197, n. 2, p. 496-498, 2013.

WEAVER, D. L. Pathology evaluation of sentinel lymph nodes in breast cancer: protocol recommendations and rationale. Modern Pathology, v. 23, n. 2, p. 26-32, 2010.

WEBSTER, J. D.; KIUPEL, M.; KANEENE, J. B.; MILLER, R.; YUZBASIYANGURKAN, V. The use of KIT and tryptase expression patterns as prognostic tools for 
canine cutaneous mast cell tumors. Veterinary Pathology, v. 41, n. 4, p. 371-377, 2004.

WEBSTER, J. D.; KIUPEL, M.; YUZBASIYAN-GURKAN, V. Evaluation of the kinase domain of C-KIT in canine cutaneous mast cell tumors. BMC Cancer, v. 6, p. 85, 2006.

WEBSTER, J. D.; YUZBASIYAN-GURKAN, V.; KANEENE, J. B.; MILLER, R.; RESAU, J. H.; KIUPEL, M. The role of C-KIT in tumorigenesis: evaluation in canine cutaneous mast cell tumors. Neoplasia, v. 8, n. 2, p. 104-111, 2006.

WEBSTER, J. D.; YUZBASIYAN-GURKAN, V.; MILLER, R. A.; KANEENE, J. B.; KIUPEL, M. Cellular proliferation in canine cutaneous mast cell tumors: associations with c-kit and its role in prognostication. Veterinary Pathology, v. 44, p. 298-308, 2007.

WEBSTER, J. D.; YUZBASIYAN-GURKAN, V.; THAMM, D. H.; HAMILTON, E.; KIUPEL, M. Evaluation of prognostic markers for canine mast cell tumors treated with vinblastine and prednisone. BMC Veterinary Research, v. 4, p. 32, 2008.

WEISSE, C.; SHOFER, F. S.; SORENMO, K. Recurrence rates and sites for grade II canine cutaneous mast cell tumors following complete surgical excision. Journal of the American Animal Hospital Association, v. 38, p. 71-73, 2002.

WELLE, M. M.; BLEY, C. R.; HOWARD, J.; RUFENACHT, S. Canine mast cell tumours: a review of the pathogenesis, clinical features, pathology and treatment. Veterinary Dermatology, v. 19, n. 6, p. 321-339, 2008.

WHITE, C. R.; HOHENHAUS, A. E.; KELSEY, J.; PROCTER-GRAY, E. Cutaneous mast cell tumors:associations with spay/neuter status, breed, body size, and phylogenetic cluster. Journal of the American Animal Hospital Association, v. 47, n. 3, p. 210-216, 2011.

WIGLE, J. T.; OLIVER, G. Prox1 function is required for the development of the murine lymphatic system. Cell, v. 98, n. 6, p. 769-778, 1999.

WILLIAMS, L. E.; PACKER, R. A. Association between lymph node size and metastasis in dogs with oral malignant melanoma: 100 cases (1987-2001). Journal of the American Veterinary Medical Association, v. 222, n. 9, p. 1234-1236, 2003. 
WORLEY, D. R. Incorporation of sentinel lymph node mapping in dogs with mast cell tumours: 20 consecutive procedures. Veterinary and Comparative Oncology, v. 12, n. 3, p. 215-226, 2012.

WU, H.; HAYASHI, T.; INOUE, M. Immunohistochemical expression. Of Mdm2 and p53 in canine cutaneous mast cell tumours. Journal of Veterinary Medicine, v. 53, p. 53-68, 2006.

YAMAGAMI, T.; KOBAYASHI, T.; TAKAHASHI, K.; SUGIYAMA, M. Prognosis for canine mammary tumors based on TNM and histologic classification. Journal of Veterinary Medical Science, v. 58, p. 1079-1083, 1996.

YANG, F.; TRAN, T. A.; CARLSON, J. A.; HIS, E. D.; ROSS, C. W.; ARBER, D. A. Paraffin section immunophenotype of cutaneous and extracutaneous mast cell disease. Comparison to other hematopoietic neoplasms. American Journal of Surgycal Pathology, v. 24, p. 703-709, 2000.

YIN, L.; GRANDI, N.; RAUM, E. Meta-analysis: longitudinal studies of serum vitamin $\mathrm{D}$ and colorectal cancer risk. Alimentary Pharmacology \& Therapeutics, v. 30, p. 113-125, 2009.

YOUNG, B.; LOWE, J. S.; STEVENS, A.; HEATH, J. W. Tecidos conjuntivos e de sustentação. In: Histologia funcional. 2. ed. Rio de Janeiro: Elsevier, 2007. cap. 4 , p. $65-81$.

ZAVODOVSKAYA, R.; CHIEN, M. B.; LONDON, C. A. Use of kit internal tandem duplications to establish mast cell tumor clonality in 2 dogs. Journal of Veterinary Internal Medicine, v. 18, n. 6, p. 915-917, 2004.

ZEMKE, D.; YAMINI, B.; YUZBASIYAN-GURKAN, V. Mutations in the juxtamembrane domain of C-KIT are associated with higher grade mast cell tumors in dogs. Veterinary Pathology, v. 39, n. 5, p. 529-535, 2002.

ZINKL, J. G.; KEETON, K. S. Lymph node cytology. California Veterinarian, v. 35, n. 5 , p. 20-23, 1981. 
